\title{
Is Nanotechnology Helping in the Fight Against COVID-19?
}

\begin{abstract}
Valéria Maria de Oliveira Cardoso, Bruna Juliana Moreira, Edson José Comparetti, Isabella Sampaio, Leonardo Miziara Barboza Ferreira, Paula Maria Pincela Lins and Valtencir Zucolotto*
\end{abstract}

Nanomedicine and Nanotoxicology Group, São Carlos Institute of Physics, University of São Paulo, São Carlos, Brazil

The novel coronavirus disease (COVID-19) pandemic represents an unprecedented public health concern. The disease, which has an incredibly high spreading rate, was discovered in late December 2019, in Wuhan, Hubei province, China. The virus that causes COVID-19, known as Severe Acute Respiratory Syndrome Coronavirus 2 (SARS-CoV-2), is responsible for the infection of more than 21.8 million individuals and more than 772 thousand deaths in 216 countries, numbers which are still rising. Currently,

OPEN ACCESS

Edited by:

Ajeet Kaushik,

Florida Polytechnic University,

United States

Reviewed by:

Yannan Yang,

The University of

Queensland, Australia

Vineet Kumar

Fayetteville State University

United States

Sneham Tiwari,

Florida International University,

United States

*Correspondence:

Valtencir Zucolotto

zuco@ifsc.usp.br

Specialty section:

This article was submitted to

Nanomaterials,

a section of the journal

Frontiers in Nanotechnology

Received: 29 July 2020

Accepted: 26 August 2020

Published: 10 November 2020

Citation:

Cardoso VMO, Moreira BJ Comparetti EJ, Sampaio I, Ferreira

$L M B$, Lins PMP and Zucolotto $V$

(2020) Is Nanotechnology Helping in

the Fight Against COVID-19?

Front. Nanotechnol. 2:588915.

doi: $10.3389 /$ fnano.2020.588915 there are no vaccines or antiviral treatments officially approved for the prevention or treatment of COVID-19. Since its appearance, several therapeutic approaches have been tested, including the use of repurposing drugs, such as broad-spectrum antivirals, nucleoside analogs, protease inhibitors, immunomodulators, and plasma therapies, among others. However, these strategies have not shown great clinical benefits and are only administered to attenuate the symptoms. Although many therapeutic strategies are being tested against COVID-19, more efforts should be devoted to fighting the virus. Nanomaterials represent a powerful tool against COVID-19 since they can be designed to act directly toward the infection, increase the effectiveness of conventional antiviral drugs, or even to trigger the immune response of the patient. Advances in nanotechnology over the past decades allow us to develop new nanomaterials and step forward in the application of new technological tools. This review addresses aspects related to the structural characteristics of the virus, the mechanisms involved in the infection, and therapies that are currently used against COVID-19. This review discusses nanotechnology-based strategies for the prevention, diagnosis, and treatment of COVID-19, including nanomaterials for face masks and surface sterilization, adjuvants, vaccine delivery nanosystems, and point-of-care tests, providing a perspective on how nanotechnology could be an applied in the fight against COVID-19.

Keywords: nanotechnology, nanomaterials, antiviral drugs, vaccine, nanomaterials for prevention diagnosis and therapy, COVID-19, SARS-CoV-2

\section{INTRODUCTION}

For approximately two decades, the world has faced several outbreaks of viral diseases, including Ebola, Influenza A (H1N1), Severe Acute Respiratory Syndrome (SARS), Middle East Respiratory Syndrome (MERS), and Zika. All of these diseases had a significant impact on the global economy and public health (Boopathi et al., 2020). SARS was the first epidemic of the twenty-first century, reported in November 2002 in Guangdong, China, followed by MERS, in Jeddah, Saudi Arabia, a 
decade later in June 2012 (Lau and Chan, 2015; Zheng et al., 2019). In November 2019, the total number of confirmed cases of MERS-CoV infection reported by the World Health Organization (WHO) was 2,494, including 858 deaths, covering 27 countries. During the SARS-CoV outbreak, 26 countries were affected, with 8,096 confirmed cases and 744 deaths (Hassan et al., 2020; Hua et al., 2020; Wang et al., 2020a).

In December 2019, a new coronavirus (CoV), causing atypical pneumonia was reported in Wuhan, China (Du et al., 2020). The Chinese Center for Disease Control and Prevention identified the virus and classified it as Severe Acute Respiratory Syndrome CoV-2 (SARS-CoV-2) (Anastasopoulou and Athanasia, 2020; Lai et al., 2020; Wang et al., 2020). Since then, the infection from SARS-CoV-2 has increased exponentially, transforming an epidemic into a pandemic in a short time. The $\mathrm{CoV}$ disease 2019 (COVID-19) was declared a public health emergency of international concern by the WHO on March 11, 2020 (Adhikari et al., 2020; Hageman, 2020; Zhu N. et al., 2020).

SARS-CoV-2 has infected more than 21.8 million individuals, causing more than 772 thousand deaths in 216 countries: numbers that are still increasing (World Health Organization, 2020d). COVID-19 is considered to be one of the greatest humanitarian crises and, due to the severity of this situation, huge efforts have been made, aimed at fighting against the disease (Li et al., 2020; Liu et al., 2020; Walls et al., 2020). Among infected people, the common symptoms of COVID-19 are cough (68.7\%), fever $(85.6 \%)$, fatigue $(39.4 \%)$ in addition to the loss of taste and smell. In more severe cases, other conditions have been reported such as pneumonia, difficulty in breathing, and ground-glass opacity in the lung. These symptoms have been used to screen suspected cases that are subsequently subjected to radiological exams of the chest, such as computed tomography and X-Ray (Huang C. et al., 2020; Rothan and Byrareddy, 2020; Weiss et al., 2020).

Studies show that the main route of transmission of SARS-CoV-2 is through contaminated droplets that are expelled by infected people, for example, by coughing or sneezing. Individuals can become infected by direct contact or indirectly via fomites. Direct contact transmission occurs through contact with saliva, respiratory secretions, or droplets, which are expelled by infected persons through cough, sneezes, or conversation. Indirect contact transmission involves contact of a susceptible host with a contaminated object or surface (fomite transmission) (Sharma et al., 2020; World Health Organization, 2020c; Yee et al., 2020). The infection is usually confirmed by the identification of the viral genetic material in the blood and secretion samples using the reverse transcription-polymerase chain reaction (RT-PCR) technique (Fehr and Perlman, 2015; Law et al., 2020). This diagnostic method is considered to be the gold standard for COVID-19 due to its high specificity and accuracy. However, the analyses require specialized professionals and expensive equipment, which need centralized laboratories. In the current situation, there is a high demand for these analyzes, which is overloading specialized centers and caused a critical delay in the final results of infected patients (Chhikara et al., 2020; Law et al., 2020).
There is currently no vaccine or clinically approved therapy for patients with COVID-19 (Aanouz et al., 2020; Astuti and Ysrafil, 2020). The standard treatment is based on repurposing antiviral drugs, an emerging strategy through which safe drugs are used to control emerging human diseases. However, it is important to highlight that several drugs have not generated clinical benefits and are recommended for restricted use, under supervision from the WHO (Senanayake, 2020). Therefore, these treatments are used to attenuate symptoms. Although some biomolecules are effective against $\mathrm{CoV}$ in vitro and in vivo, antiviral activity has not shown great results in humans (Srivastava and Saxena, 2020).

Nanotechnology-based therapeutic strategies represent a promising approach to overcome the limitations found in prevention, diagnosis, and therapies against COVID-19 (Weiss et al., 2020). To manage this disease, nanomaterials with antiviral properties can be used in personal protective equipment and in disinfection protocols to prevent SARS-CoV-2 contamination (Weiss et al., 2020) or as nanomaterials-based vaccines or immunomodulators (Chauhan et al., 2020; Weiss et al., 2020). In diagnosis, nanomaterials can also be used for the development of simple, fast, and low-cost methods to detect SARS-CoV-2. For treatment, the nanosystems are applied in the controlled delivery of antiviral and biomolecules to the pulmonary system, for example, to inhibit viral replication or to inactivate viral particles (Weiss et al., 2020).

This review introduces the main aspects of COVID-19, such as the structural characteristics of the virus, infection mechanisms, and treatments currently available. We also presented a discussion about how nanotechnology can be applied against this disease, detailing the most promising nanomaterials and the application possibilities, with properties and advantages over conventional strategies. Furthermore, we hope that the nanotechnology-based strategies addressed in this study can guide researchers in the development of new methods for the prevention, diagnosis, and treatment of COVID-19.

\section{STRUCTURE OF SARS-CoV-2}

SARS-CoV-2 is an enveloped virus with positive-sense singlestranded RNA [(+)ssRNA] that has a spherical shape and a diameter range of $60-140 \mathrm{~nm}$. This virus belongs to the Coronaviridae family, a group of viruses capable of infecting animals and humans. Based on the genomic structure, the family is organized into four genera, namely $\alpha-\mathrm{CoV}, \beta-\mathrm{CoV}, \gamma-\mathrm{CoV}$, and $\delta$-CoV. There are several types of human $\mathrm{CoV}$, among them MERS-CoV, SARS-CoV, and SARS-CoV-2, all belonging to $\beta$-CoV genera (Cao Y. et al., 2020; Ortiz-Prado et al., 2020).

Analyses of the SARS-CoV-2 genome revealed structural proteins similar to other types of $\mathrm{CoV}$. The identification of spike (S), envelope (E), membrane (M), and nucleocapsid (N) proteins enable us to understand the activities and functions of the COVID-19 virus (Figure 1). For example, they have an attachment and entry mechanism are closely related to the binding of $S$ protein to the host target cell angiotensinconverting enzyme 2 (ACE2) receptor, an integral membrane 


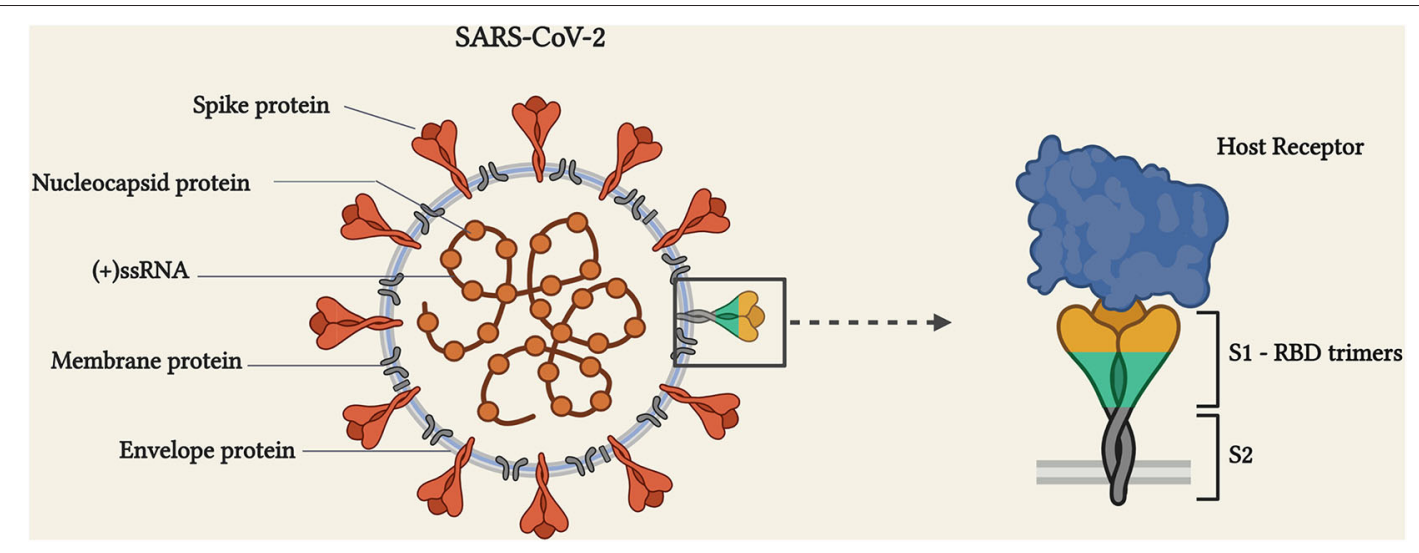

FIGURE 1 | Schematic representation of the SARS-CoV-2 structure and spike-receptor binding mechanism (figure created with BioRender.com).

protein responsible for cleaving angiotensin I and II on the plasma membrane of human epithelial cells (Yan et al., 2020).

Localized in the endoplasmic reticulum-Golgi region, the $\mathrm{N}$ proteins interact with the $(+)$ ssRNA ( $30 \mathrm{~kb}$ in length) and form a helical nucleocapsid to assist viral replication within the host cell. The $\mathrm{M}$ protein has a large structure with three transmembrane domains and is responsible for defining the shape, size, and assembly of the virus. The E protein is abundantly expressed inside the vesicle trafficking organelles of the infected cell and seems to be involved at multiple stages of the virus replication cycle, and fundamental in the pathogenesis processes of SARS$\mathrm{CoV}-2$. The envelope-anchored $\mathrm{S}$ protein is a trimeric class I fusion protein that is highly glycosylated (Graham et al., 2013), which gives crown-like morphology when seen in the electron microscopy. $\mathrm{N}$ and $\mathrm{S}$ proteins are especially important because they are responsible for the viral infectivity and mediate the entry of the virus into host cells (Astuti and Ysrafil, 2020; Cao Y. et al., 2020; Jiang et al., 2020; Li et al., 2020; Shereen et al., 2020).

$\mathrm{S}$ protein comprises two functional subunits ( $\mathrm{S} 1$ and $\mathrm{S} 2$ ). The globular S1 subunit is responsible for recognition and binding to cell receptors and has a higher receptor-binding domain (RBD) in its structure. The S2 subunit is responsible for facilitating virus-cell fusion (Figure 1; Walls et al., 2020). The RBD region is crucial for virus interaction with host cells receptors and determines to some extent the host range (Li et al., 2005; Walls et al., 2020; Wu et al., 2020). SARS-CoV-2 uses the RBD region of $S$ protein to interact with human cells via the ACE2 receptor followed by protease priming at the S1/S2 site, resulting in virus entry in the host cell and pathogenesis (Tariq et al., 2020).

$\mathrm{S}$ proteins have been studied in preventive and therapeutic strategies, with monoclonal antibodies (mAbs) targeting viral surface neutralizing SARS-CoV-2 (and SARS-CoV) activity. In vitro, this approach is recognized as a promising class of biomolecules against viral diseases (Wang et al., 2020b). Structural analysis from the RBD region of SARS-CoV-2S protein can establish strong interactions with human ACE2 receptors with high affinity (Li et al., 2020; Wrapp et al., 2020).

\section{INFECTION MECHANISM OF SARS-CoV-2}

Viral entry into the host cell starts with the adsorption and interaction of the viral $S$ protein (RBD domains) to host cell ACE2 receptors. Then, $\mathrm{S}$ protein undergoes proteolytic cleavage at the S1/S2 boundary, by transmembrane serine protease 2 (TMPRSS2), promoting the S1 dissociation and S2 structural change, required for membrane fusion and viral internalization via endocytosis (Astuti and Ysrafil, 2020; Yan et al., 2020).

After internalization $(+)$ ssRNA is released into the host cell cytosol and attached to the ribosomes, resulting in the translation of two large polyproteins (ppla and pplab polyproteins), which will be subsequently cleaved into smaller components for the folding and packaging of new virions (Boopathi et al., 2020). The proteolytic cleavage, as well as the replication and new virions production, are mediated by enzymes, namely the papainlike proteases (PL-pro), 3C-like proteases (3CL-pro), and RNAdependent RNA polymerase (RdRp). These enzymes are crucial for the survival and transmission of SARS-CoV-2 and are currently being considered as potential therapeutic targets (Naqvi et al., 2020). Novel viruses are formed (maturation process) and transported to the cellular surface in vesicles and, after being secreted (via exocytosis), start to infect other cells (Eastman et al., 2020; Hoffmann et al., 2020b; Wang et al., 2020). Figure 2 shows the mechanisms involved in the attachment, entry, and replication of SARS-CoV-2.

During infection by SARS-CoV-2, the viral S protein on the surface of the virus binds to the ACE2 receptor and enters target cells via endocytosis, after processing the $\mathrm{S}$ protein by the TMPRSS2 (1). After cell membrane fusion and release of the viral (+)ssRNA into the cell cytosol (2), the viral polymerase protein is translated (3), replicated, and there is a transcription of the RNA genome (- sense) (4). The replicated genomic RNA and subgenomic RNA transcripts lead to translation of 


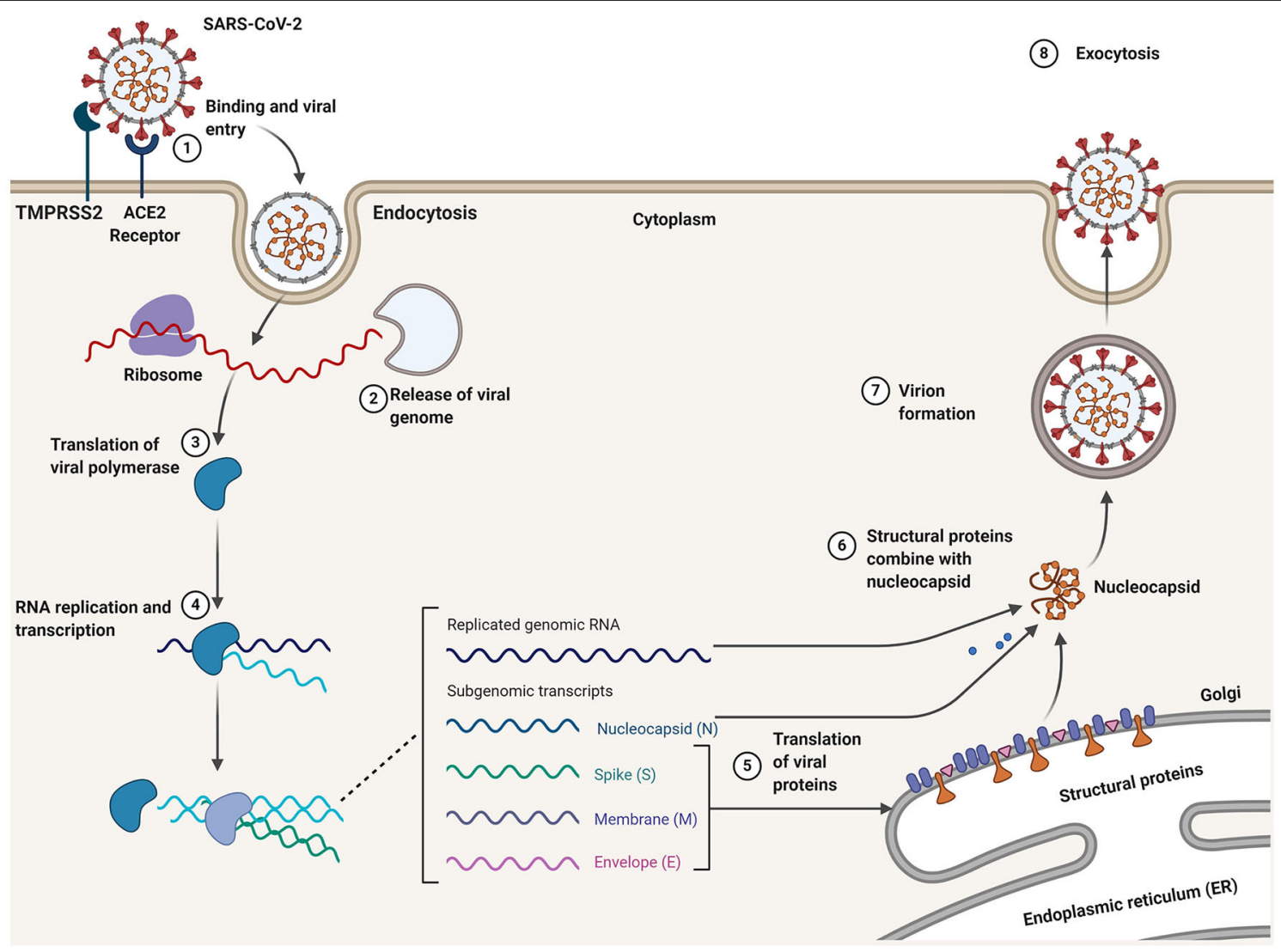

FIGURE 2 | Infection mechanism and life cycle of SARS-CoV-2 in the host cells.

the viral structural proteins (N, M, E, and S) (5) and, finally, the combination of S, E, M proteins with nucleocapsid (6), which allows the formation of new virions (7) that are then released from the host cells via exocytosis (8) (Figure created with BioRender.com).

\section{THERAPEUTIC APPROACHES AGAINST COVID-19}

There is currently no clinically approved treatment for COVID19, and the therapeutic strategies that we do have are for managing symptoms. However, a few specific antiviral drugs, with several molecules, are undergoing clinical trials. These therapeutic interventions may extend to either direct-acting antiviral agents or immunomodulatory adjuvants, which have been investigated since the beginning of the COVID-19 outbreak (Nitulescu et al., 2020).

The treatments that are adopted for managing COVID-19 are based on the main physio-pathological characteristics of the disease. Drugs can be classified as virus-targeting antiviral (VTA) if they target essential viral proteins to promote virus internalization and replication. They are host-targeting antiviral (HTA) if they target proteins located in the host infected cell or immune system (Conteduca et al., 2014). Recently, strategies focusing on virus-host interactions (VHI) have been proposed.
The main therapies that use these strategies, which are currently in the clinical trial phase, are described in Table $\mathbf{1}$.

As shown in Table 1, the limitations of antiviral therapies include a lack of specificity, which causes host cell cytotoxicity. Most of these potential drug treatments of COVID-19 are still under investigation in terms of safety and effectiveness, and current antiviral therapy has not yet achieved efficiency against COVID-19. For patient safety, the use of antivirals alone or in association with other treatments should be considered case-bycase to avoid adverse reactions. Moreover, as the development of drugs is a slow and expensive process, the COVID-19 situation requires new and more effective therapeutic alternatives. In this sense, nanotechnology can be a strong ally in the fight against COVID-19, as it brings novel potentials in terms of diagnosis, prevention, and treatment of the disease.

\section{NANO INSIGHTS INTO DIAGNOSIS, TREATMENT, AND PREVENTION OF COVID-19}

Nanotechnology can provide significant advantages in terms of its application in emergency viral diseases such as COVID19 (Lembo et al., 2018). According to the Food and Drug Administration (FDA), nanoscale systems present different physicochemical and biological properties, compared to macro 
TABLE 1 | Summary of current therapeutic strategies against COVID-19 in clinical trials.

\begin{tabular}{|c|c|c|c|c|c|c|c|}
\hline Drugs & Clinical Indications & $\begin{array}{l}\text { Analysis in coronavirus } \\
\text { (COVID-19) }\end{array}$ & Action mechanisms & Limitations & Clinical evidence & $\begin{array}{l}\text { Current number of } \\
\text { clinical trials }\end{array}$ & References \\
\hline \multicolumn{8}{|c|}{ VIRUS-TARGETING ANTIVIRAL (VTA) } \\
\hline $\begin{array}{l}\text { Remdesivir (GS-5734) } \\
\text { (Investigational agent) }\end{array}$ & $\begin{array}{l}\text {-SARs-CoV } \\
\text {-Ebola } \\
\text {-Influenza (H1N1) } \\
\text {-MERS-CoV }\end{array}$ & $\begin{array}{l}\text { Remdesivir protects the } \\
\text { human cells against } \\
\text { SARS-CoV-2 infection, } \\
\text { improving the clinical } \\
\text { condition in the first patients } \\
\text { with COVID-19 in the USA. }\end{array}$ & $\begin{array}{l}\text { Interaction with } \\
\text { RNA-dependent RNA } \\
\text { Polymerase (RdRp) to } \\
\text { inhibit viral replication. }\end{array}$ & $\begin{array}{l}\text { Safety and efficacy not } \\
\text { established. } \\
\text { Common adverse } \\
\text { effects: increased liver } \\
\text { enzymes, kidney injury. }\end{array}$ & $\begin{array}{l}\text { Gilead Sciences } \\
\text { announced the } \\
\text { remdesivir efficacy in a } \\
\text { study with } 53 \text { patients } \\
\text { infected SARs-CoV- } 2 \text {. } \\
\text { The results showed a } \\
\text { reduced mortality rate } \\
\text { of severe cases. To } \\
\text { confirm its } \\
\text { effectiveness, the } \\
\text { number of people } \\
\text { submitted to this } \\
\text { treatment needs to be } \\
\text { extended }\end{array}$ & 34 ongoing clinical trials & $\begin{array}{l}\text { Abbasi-Oshaghi et al., } \\
\text { 2020; Grein et al., } \\
\text { 2020; Holshue et al., } \\
\text { 2020; Jorgensen et al., } \\
\text { 2020; Wang M. et al., } \\
2020\end{array}$ \\
\hline $\begin{array}{l}\text { Faviparivir (T-705) } \\
\text { (Avigan }^{\circledR}, \text { Favilavir) } \\
\text { (Investigational agent) }^{\text {Intion }}\end{array}$ & $\begin{array}{l}\text {-Influenza A (H1N1) } \\
\text {-Ebola }\end{array}$ & $\begin{array}{l}\text { Ongoing at clinical trials with } \\
\text { unproven efficiency. }\end{array}$ & $\begin{array}{l}\text { It inhibits RNA polymerase } \\
\text { activity to block virus } \\
\text { replication. }\end{array}$ & $\begin{array}{l}\text { Efficacy still not proven. } \\
\text { Common adverse } \\
\text { effects: diarrhea, } \\
\text { increased liver } \\
\text { enzymes, } \\
\text { hyperuricemia, } \\
\text { decreased neutrophil } \\
\text { count. } \\
\text { Severe effects: } \\
\text { Increased risk for } \\
\text { embryotoxicity } \\
\text { and teratogenicity. }\end{array}$ & $\begin{array}{l}\text { A recent study showed } \\
\text { that favipiravir was able } \\
\text { to restrict COVID-19 } \\
\text { progression and } \\
\text { favored the viral } \\
\text { clearance. }\end{array}$ & 25 ongoing clinical trials & $\begin{array}{l}\text { Cai et al., 2020; } \\
\text { Jorgensen et al., } 2020\end{array}$ \\
\hline $\begin{array}{l}\text { Ribavirin (Repurposed } \\
\text { agent) }\end{array}$ & $\begin{array}{l}\text {-Hepatitis C } \\
\text {-HCV } \\
\text {-SARS } \\
\text {-MERS } \\
\text {-Respiratory syncytial } \\
\text { virus (RSV) infection }\end{array}$ & $\begin{array}{l}\text { Ribavirin has demonstrated } \\
\text { good results against } \\
\text { SARs-CoV. Given the high } \\
\text { similarity of SARS-CoV and } \\
\text { SARs-CoV-2 Mpros, } \\
\text { Ribavirin has been } \\
\text { considered a potential agent } \\
\text { against COVID-19. }\end{array}$ & $\begin{array}{l}\text { Interference in the } \\
\text { replication of RNA and } \\
\text { DNA viruses and inhibits } \\
\text { natural guanosine } \\
\text { generation by direct action } \\
\text { under inosine } \\
\text { monophosphate } \\
\text { dehydrogenase }\end{array}$ & $\begin{array}{l}\text { High risk of anemia; } \\
\text { potential teratogen in } \\
\text { pregnancy. May cause } \\
\text { dose-dependent } \\
\text { hematologic toxicity. }\end{array}$ & $\begin{array}{l}\text { Ribavirin used only in } \\
\text { association with } \\
\text { Lopinavir/ Ritonavir and } \\
\text { IFN-beta. } \\
\text { More studies are } \\
\text { required to evaluate } \\
\text { its efficacy }\end{array}$ & 9 ongoing clinical trials & $\begin{array}{l}\text { Kandeel and } \\
\text { Al-Nazawi, 2020; } \\
\text { Khalili et al., 2020 }\end{array}$ \\
\hline $\begin{array}{l}\text { Lopinavir/ritonavir } \\
\text { Kaletra }^{\circledR} \text { (Repurposed } \\
\text { agent) }\end{array}$ & -HIV type 1 & $\begin{array}{l}\text { Already used against SARS } \\
\text { CoV, with moderate activity } \\
\text { in Vero E6 cells. }\end{array}$ & $\begin{array}{l}\text { Inhibition of the viral Mpro } \\
\text { (3CL-pro) or PL-pro }\end{array}$ & $\begin{array}{l}\text { Increase the risk of } \\
\text { cardiac arrhythmias, } \\
\text { pancreatitis, cardiac } \\
\text { conduction } \\
\text { abnormalities, } \\
\text { hepatotoxicity, } \\
\text { hemophilia, others. }\end{array}$ & $\begin{array}{l}\text { Lopinavir did not show } \\
\text { clinical improvement in } \\
\text { a clinical trial with } 199 \\
\text { patients }\end{array}$ & 69 ongoing clinical trials & $\begin{array}{l}\text { Cao B. et al., 2020; } \\
\text { Nitulescu et al., } 2020\end{array}$ \\
\hline
\end{tabular}


TABLE 1 | Continued

\begin{tabular}{|c|c|c|c|c|c|c|c|}
\hline Drugs & Clinical Indications & $\begin{array}{l}\text { Analysis in coronavirus } \\
\text { (COVID-19) }\end{array}$ & Action mechanisms & Limitations & Clinical evidence & $\begin{array}{l}\text { Current number of } \\
\text { clinical trials }\end{array}$ & References \\
\hline $\begin{array}{l}\text { Danoprevir in } \\
\text { combination with } \\
\text { Ritonavir (Ganovo }\end{array}$ & $\begin{array}{l}\text {-Anti-Hepatite C viral } \\
(\mathrm{HCV})\end{array}$ & $\begin{array}{l}\text { A small clinical trial (just } 11 \\
\text { patients with COVID-19) } \\
\text { were treated with } \\
\text { Danoprevir. After } 4 \text { to } 12 \\
\text { days of their use, all the } \\
\text { patients recovered, } \\
\text { suggesting great efficiency } \\
\text { against SARS-CoV-2. }\end{array}$ & $\begin{array}{l}\text { It's inhibited HCV NS3/4A } \\
\text { protease in viral } \\
\text { replication, suppressing } \\
\text { host response to viral } \\
\text { infection. }\end{array}$ & $\begin{array}{l}\text { There studies prove } \\
\text { danoprevir efficiency, } \\
\text { evaluated in various } \\
\text { randomized clinical } \\
\text { trials. }\end{array}$ & $\begin{array}{l}\text { The treatment with } \\
\text { danoprevir/ritonavir } \\
\text { suppressed viral } \\
\text { replication and improve } \\
\text { the clinical condition of } \\
\text { patients with COVID-19 } \\
\text { moderate stage. }\end{array}$ & $\begin{array}{l}2 \text { complete clinical trials } \\
\text { (NCT04345276 and } \\
\text { NCT04291729) results } \\
\text { not reported yet. }\end{array}$ & $\begin{array}{l}\text { Chen et al., 2020; } \\
\text { Drugbank, } 2020\end{array}$ \\
\hline \multicolumn{8}{|c|}{ HOST-TARGETING ANTIVIRAL (HTA) } \\
\hline Convalescent Plasma & $\begin{array}{l}\text {-Inflammatory process } \\
\text { induced by } \\
\text { infectious agents } \\
\text {-Sepsis } \\
\text {-H1N1 } \\
\text {-Spanish influenza A } \\
\text {-SARs-CoV } \\
\text {-MERS-CoV }\end{array}$ & $\begin{array}{l}\text { The antibodies against } \\
\text { SARS-CoV-2 isolated from } \\
\text { the convalescent plasma of } \\
\text { patients with COVID-19 } \\
\text { must provide short-term } \\
\text { passive immunity against } \\
\text { the virus. }\end{array}$ & $\begin{array}{l}\text { Direct virus neutralization, } \\
\text { controlling molecules from } \\
\text { the overactive immune } \\
\text { system (i.e., cytokine } \\
\text { storm, Th1/Th17 ratio, } \\
\text { complement activation). } \\
\text { Immunomodulation of a } \\
\text { hypercoagulable state }\end{array}$ & $\begin{array}{l}\text { High costs. There is a } \\
\text { lack of studies } \\
\text { (randomized controlled } \\
\text { trials). Passive } \\
\text { immunization usually } \\
\text { has a short duration of } \\
\text { the effects. }\end{array}$ & $\begin{array}{l}\text { Five patients with } \\
\text { severe COVID-19 } \\
\text { exhibited a significant } \\
\text { clinical improvement } \\
\text { after receiving the } \\
\text { infusion of } \\
\text { convalescent plasma. } \\
\text { In another clinical } \\
\text { study, } 10 \text { patients with } \\
\text { COVID-19 were also } \\
\text { cured using } \\
\text { convalescent } \\
\text { plasma treatments. }\end{array}$ & $\begin{array}{l}99 \text { ongoing clinical } \\
\text { trials. }\end{array}$ & $\begin{array}{l}\text { Mair-Jenkins et al., } \\
\text { 2014; Duan et al., } \\
\text { 2020; Marando and } \\
\text { Tamburello, 2020; } \\
\text { Rojas et al., 2020; } \\
\text { Zhao and He, 2020 }\end{array}$ \\
\hline $\begin{array}{l}\text { Intravenous } \\
\text { immunoglobulin (IVI)-a } \\
\text { pool of IgG } \\
\text { (Adjunctive/Supportive } \\
\text { therapy) }\end{array}$ & $\begin{array}{l}\text {-Autoimmune diseases: } \\
\text {-Dermatomyositis } \\
\text {-Kawasaki disease } \\
\text {-Multiple sclerosis } \\
\text {-Lupus } \\
\text {-Chronic lymphocytic } \\
\text {-Thrombocytopenic } \\
\text { purpura } \\
\text {-Bacterial and } \\
\text { fungal infections } \\
\text {-Severe viral infections } \\
\text {-HIV infection } \\
\text {-SARS -MERS }\end{array}$ & $\begin{array}{l}\text { IVI (obtained from the } \\
\text { plasma of COVID-19 } \\
\text { recovered patients) is } \\
\text { composed of specific } \\
\text { antibodies to suppress the } \\
\text { virus activity and modulate } \\
\text { immune response to } \\
\text { SARS-COV-2 infection. }\end{array}$ & $\begin{array}{l}\text { Multiple activities: } \\
\text { modulates the } \\
\text { complement activation; } \\
\text { suppresses idiotypic } \\
\text { antibody; suppresses } \\
\text { inflammatory mediators } \\
\text { (cytokines, chemokines, } \\
\text { and metalloproteinases) }\end{array}$ & $\begin{array}{l}\text { Lack of donators. } \\
\text { Severe adverse events: } \\
\text { acute renal failure, } \\
\text { thromboembolic } \\
\text { events, aseptic } \\
\text { meningitis, } \\
\text { neutropenia, } \\
\text { autoimmune hemolytic } \\
\text { anemia, nephrotoxicity, } \\
\text { systemic vasculitis, } \\
\text { and, mainly, } \\
\text { renal insufficiency. }\end{array}$ & $\begin{array}{l}\text { A study demonstrated } \\
\text { satisfactory clinical } \\
\text { results of three patients } \\
\text { after receiving } \\
\text { high-doses of IVI. }\end{array}$ & $\begin{array}{l}\text { Ten ongoing clinical } \\
\text { trials }\end{array}$ & $\begin{array}{l}\text { Keller and Stiehm, } \\
\text { 2000; Simon and } \\
\text { Späth, 2003; Katz } \\
\text { et al., 2007; Khanna } \\
\text { et al., 2008; Arabi et al., } \\
\text { 2014; Cao W. et al., } \\
\text { 2020; Dalakas, 2020; } \\
\text { González-Gay et al., } \\
\text { 2020; Lotfi et al., } 2020\end{array}$ \\
\hline $\begin{array}{l}\text { Tocilizumab } \\
\text { (Recombinant } \\
\text { humanized mAb) } \\
\text { Actemra }^{\circledR} \text {, } \\
\text { RoActemra } \\
\text { (Adjunctive/Supportive } \\
\text { therapy) }\end{array}$ & $\begin{array}{l}\text { Rheumatoid arthritis; } \\
\text { cytokine release } \\
\text { syndrome (CRS) }\end{array}$ & $\begin{array}{l}\text { It could prevent cytokine } \\
\text { release syndrome (CRS), } \\
\text { symptoms that occur in the } \\
\text { cases of severe COVID-19. }\end{array}$ & $\begin{array}{l}\text { Interaction with IL-6 } \\
\text { receptor alleviates the } \\
\text { inflammatory responses } \\
\text { and prevents immune } \\
\text { dysregulation produced } \\
\text { by inflammatory response. }\end{array}$ & $\begin{array}{l}\text { High cost, } \\
\text { Immunosuppression } \\
\text { followed infections, } \\
\text { Hypertension, } \\
\text { Hepatotoxicity, } \\
\text { Gastrointestinal } \\
\text { perforations, } \\
\text { Hypersensitivity reaction }\end{array}$ & $\begin{array}{l}\text { A study verified the } \\
\text { decrease in C-reactive } \\
\text { protein levels in } 15 \\
\text { patients with } \\
\text { COVID-19, improving } \\
\text { the disease condition } \\
\text { after administration of a } \\
\text { few doses. }\end{array}$ & 54 ongoing clinical trials & $\begin{array}{l}\text { Le et al., 2018; Luo P. } \\
\text { et al., 2020; Xu et al., } \\
2020\end{array}$ \\
\hline
\end{tabular}


TABLE 1 | Continued

\begin{tabular}{|c|c|c|c|c|c|c|c|}
\hline Drugs & Clinical Indications & $\begin{array}{l}\text { Analysis in coronavirus } \\
\text { (COVID-19) }\end{array}$ & Action mechanisms & Limitations & Clinical evidence & $\begin{array}{l}\text { Current number of } \\
\text { clinical trials }\end{array}$ & References \\
\hline $\begin{array}{l}\text { Sarilumab } \\
\text { (Adjunctive/Supportive } \\
\text { therapy) }\end{array}$ & $\begin{array}{l}\text {-Rheumatoid arthritis } \\
\text {-Cytokine release } \\
\text { syndrome (CRS) }\end{array}$ & $\begin{array}{l}\text { mAb with the ability to } \\
\text { combat CRS and } \\
\text { pulmonary symptoms in } \\
\text { severe cases of COVID-19 }\end{array}$ & $\begin{array}{l}\text { Interaction with IL-6 } \\
\text { receptor effectively blocks } \\
\text { IL-6 signaling. }\end{array}$ & $\begin{array}{l}\text { Still, there are no } \\
\text { enough data to } \\
\text { recommend the use of } \\
\text { sarilumab in the } \\
\text { treatment of COVID-19. }\end{array}$ & $\begin{array}{l}\text { Sarilumab application is } \\
\text { being studied. }\end{array}$ & 15 ongoing clinical trials & Lee, 2018 \\
\hline $\begin{array}{l}\text { Corticosteroids (Steroid } \\
\text { hormones) } \\
\text { (Adjunctive/Supportive } \\
\text { therapy) }\end{array}$ & Inflammation & $\begin{array}{l}\text { Reduce the inflammatory } \\
\text { response in the lungs } \\
\text { responsible for acute injury } \\
\text { and acute respiratory } \\
\text { distress syndrome. }\end{array}$ & $\begin{array}{l}\text { Interaction with } \\
\text { glucocorticoid steroid (GR) } \\
\text { receptors present in the } \\
\text { cell's cytoplasm neutralize } \\
\text { the pro-inflammatory } \\
\text { cytokines for avoiding the } \\
\text { inflammatory process. }\end{array}$ & $\begin{array}{l}\text { It can lead to delayed } \\
\text { viral clearance and } \\
\text { increase the risk of } \\
\text { secondary infection. }\end{array}$ & $\begin{array}{l}\text { There is some benefit in } \\
\text { the early acute } \\
\text { infection, and its } \\
\text { efficacy in the } \\
\text { treatment of COVID-19 } \\
\text { is still under discussion } \\
\text { at WHO. }\end{array}$ & $\begin{array}{l}\text { Three completed } \\
\text { clinical trials. } \\
35 \text { ongoing clinical trials }\end{array}$ & $\begin{array}{l}\text { Russell et al., 2020; } \\
\text { Zha et al., } 2020\end{array}$ \\
\hline $\begin{array}{l}\text { Type I (IFN- } \alpha \text { or IFN- } \beta \text { ) } \\
\text { Interferon-based } \\
\text { therapy } \\
\text { (Adjunctive/Supportive } \\
\text { therapy) }\end{array}$ & $\begin{array}{l}\text {-Leukemia } \\
\text {-Melanoma } \\
\text {-Lymphoma } \\
\text {-Condylomata } \\
\text { acuminata } \\
\text {-Kaposi sarcoma } \\
\text {-Hepatitis B } \\
\text {-Hepatitis C }\end{array}$ & $\begin{array}{l}\text { Potential against SARS-CoV } \\
\text { and MERS-CoV outbreaks }\end{array}$ & $\begin{array}{l}\text { The slowdown viral } \\
\text { replication inhibits the } \\
\text { secretion of cytokines } \\
\text { responsible for promoting } \\
\text { the activation of adaptive } \\
\text { immunity. }\end{array}$ & $\begin{array}{l}\text { It may fail to suppress } \\
\text { viral replication with } \\
\text { some side effects when } \\
\text { prescribing in disease } \\
\text { late stages. }\end{array}$ & $\begin{array}{l}\text { Treatment with IFN- } \alpha \text { or } \\
\text { IFN- } \beta \text { ( } 50 \mathrm{IU} / \mathrm{mL} \text { ) } \\
\text { reduced viral charge in } \\
\text { Vero cells. The results } \\
\text { revealed that } \\
\text { SARS-CoV-2 is more } \\
\text { sensitive concerning } \\
\text { other human } \\
\text { pathogenic viruses. }\end{array}$ & 63 ongoing clinical trials & $\begin{array}{l}\text { Chan et al., 2015; } \\
\text { Abbasi-Oshaghi et al., } \\
\text { 2020; Mantlo et al., } \\
\text { 2020; Sallard et al., } \\
2020\end{array}$ \\
\hline \multicolumn{8}{|c|}{ VIRUS-HOST INTERACTIONS (VHI) } \\
\hline $\begin{array}{l}\text { Chloroquine and } \\
\text { Hydrochloquine } \\
\text { (Aralen }^{\circledR} \text {, Plaquenil }{ }^{\circledR} \text {, } \\
\text { Quineprox }{ }^{\circledR} \text {, others) } \\
\text { (Repurposed agent) }\end{array}$ & $\begin{array}{l}\text { Cloroquine: } \\
\text {-Malaria } \\
\text {-Extra-intestinal } \\
\text { amebiasis } \\
\text {-SARS-CoV } \\
\text { Hydroxychloroquine: } \\
\text {-Lupus erythematosus } \\
\text {-Malaria } \\
\text {-Rheumatoid arthritis }\end{array}$ & $\begin{array}{l}\text { Chloroquine and } \\
\text { hydroxychloroquine inhibit } \\
\text { viral entry and endocytosis } \\
\text { by increasing endosomal } \\
\text { pH and interfering in ACE2 } \\
\text { glycosylation process. In } \\
\text { addition, both drugs have } \\
\text { host immunomodulatory } \\
\text { e?ects. }\end{array}$ & $\begin{array}{l}\text { As a weak base, } \\
\text { chloroquine prevents } \\
\text { endocytosis. Chloroquine } \\
\text { also suppresses the } \\
\text { production/release of } \\
\text { TNF- } \alpha \text { and IL-6. } \\
\text { In the case of } \\
\text { SARS-CoV-2, both } \\
\text { chloroquine and } \\
\text { hydrochloride inhibit the } \\
\text { glycosylation of ACE2 } \\
\text { receptor chains, limiting } \\
\text { ligand recognition of these } \\
\text { receptors, rendering the } \\
\text { viral S protein unable to } \\
\text { mediate cell entry. }\end{array}$ & $\begin{array}{l}\text { The lack of safety and } \\
\text { efficacy was evidenced } \\
\text { in clinical studies, with } \\
\text { the long term use of } \\
\text { Chloroquine and } \\
\text { hydroxychloroquine } \\
\text { increasing the risk of } \\
\text { cardiac arrhythmias, } \\
\text { hypoglycemia, retinal } \\
\text { damage, particularly. }\end{array}$ & $\begin{array}{l}\text { The efficacy of } \\
\text { hydroxychloroquine or } \\
\text { chloroquine, often used } \\
\text { in association with a } \\
\text { second-generation } \\
\text { macrolide, was } \\
\text { evaluated in a } \\
\text { multinational } \\
\text { investigation involving } \\
96032 \text { patients. The } \\
\text { study evidenced that } \\
\text { chloroquine is } \\
\text { associated with risks of } \\
\text { ventricular arrhythmias } \\
\text { and a higher hazard for } \\
\text { in-hospital death with } \\
\text { COVID-19. }\end{array}$ & $\begin{array}{l}\text { Four clinical trials } \\
\text { completed, and } 62 \\
\text { ongoing }\end{array}$ & $\begin{array}{l}\text { Gao et al., 2020; } \\
\text { Mehta et al., 2020; } \\
\text { Nitulescu et al., } 2020\end{array}$ \\
\hline
\end{tabular}


TABLE 1 | Continued

\begin{tabular}{|c|c|c|c|c|c|c|c|}
\hline Drugs & Clinical Indications & $\begin{array}{l}\text { Analysis in coronavirus } \\
\text { (COVID-19) }\end{array}$ & Action mechanisms & Limitations & Clinical evidence & $\begin{array}{l}\text { Current number of } \\
\text { clinical trials }\end{array}$ & References \\
\hline $\begin{array}{l}\text { Camostat Mesylate } \\
\text { Foipan }{ }^{\circledR}\end{array}$ & -Chronic pancreatitis & $\begin{array}{l}\text { It blocks SARs-CoV-2 entry } \\
\text { into the cell by inhibiting } \\
\text { enzyme TMPRSS2. }\end{array}$ & $\begin{array}{l}\text { Inhibition of } \\
\text { TMPRSS2-mediated } \\
\text { glycoprotein activation, } \\
\text { preventing SARs-CoV-2 } \\
\text { entry into the host cells. }\end{array}$ & $\begin{array}{l}\text { Few studies prove drug } \\
\text { efficacy and adverse } \\
\text { effects, like skin rashes, } \\
\text { itching, gastrointestinal } \\
\text { adverse events } \\
\text { (nausea, diarrhea, and } \\
\text { abdominal pain), and } \\
\text { changes in liver } \\
\text { enzymes. } \\
\text { However, more tests } \\
\text { are required to prove } \\
\text { their efficiency in } \\
\text { COVl-19 treatment. }\end{array}$ & $\begin{array}{l}\text { Recently, camostat } \\
\text { mesylate reduced the } \\
\text { entry of MERS-CoV, } \\
\text { SARS-CoV, and } \\
\text { SARS-CoV-2 into the } \\
\text { lung cell line Calu-3, } \\
\text { without cytotoxic } \\
\text { effects. Moreover, } \\
\text { camostat mesylate } \\
\text { treatment reduced } \\
\text { infection by } \\
\text { SARS-CoV-2 in the cell } \\
\text { line studied. }\end{array}$ & $\begin{array}{l}\text { Six ongoing clinical } \\
\text { trials }\end{array}$ & $\begin{array}{l}\text { Zhou et al., 2015; } \\
\text { Hoffmann et al., } \\
\text { 2020a,b }\end{array}$ \\
\hline $\begin{array}{l}\text { Umifenovir (Arbidol }{ }^{\circledR} \text { ) } \\
\text { (repurpose agent) }\end{array}$ & $\begin{array}{l}\text {-Influenza A and B } \\
\text {-SARS-CoV }\end{array}$ & $\begin{array}{l}\text { Broad-spectrum antiviral } \\
\text { with significate activity } \\
\text { against various viruses in } \\
\text { vitro, among them, CoVs }\end{array}$ & $\begin{array}{l}\text { Umifenovir inhibits the } \\
\text { interaction between } S \\
\text { protein/ACE2 and the } \\
\text { fusion of the viral lipid } \\
\text { envelope with the host cell } \\
\text { membrane, preventing the } \\
\text { viral genes to enter the } \\
\text { nucleus. }\end{array}$ & $\begin{array}{l}\text { Safety and efficacy not } \\
\text { established. } \\
\text { Very common side } \\
\text { effects: allergic } \\
\text { reaction, } \\
\text { gastrointestinal } \\
\text { intolerance, increased } \\
\text { liver enzymes. }\end{array}$ & $\begin{array}{l}\text { A recent study reported } \\
\text { activity against and } \\
\text { SARS-CoV-2 in vitro. } \\
\text { Although limited, the } \\
\text { results showed that } \\
\text { umifenovir } \\
\text { monotherapy has more } \\
\text { efficiency than } \\
\text { lopinavir/ritonavir for } \\
\text { reducing viral load in } \\
\text { COVID-19 patients. }\end{array}$ & $\begin{array}{l}\text { Eight ongoing clinical } \\
\text { trials }\end{array}$ & $\begin{array}{l}\text { Blaising et al., 2014; } \\
\text { Dong et al., 2020; } \\
\text { Jin et al., 2020; } \\
\text { Zhu N. et al., } 2020\end{array}$ \\
\hline
\end{tabular}


and micro materials. For example, drug encapsulation into nanocarriers makes it possible to control its release rate in the target sites, improve biocompatibility and decrease toxicity in healthy tissues (Singh and Lillard, 2009; Mora-Huertas et al., 2010).

Nanomaterials also avoid viral contamination by air and contact with infected surfaces and may be especially helpful in sterilizing protective equipment and in a hospital environment. Additionally, nanomaterials exhibit electrical and optical properties that have been widely explored in the development of diagnostic methods, for example, point-ofcare (POC) biosensors. The sensitivity of detection could be improved by using nanoparticles, which enable us to identify the analysis at low concentrations. These strategies contribute to rapid diagnosis and isolation and may facilitate the treatment of people infected with SARS-CoV-2. The interactions between nanomaterials and biological interfaces are the basis for their potential (bio)medical applications (Mainardes and Diedrich, 2020).

Nanotechnology thus provides new opportunities in the fight against COVID-19 by enabling new and better forms of prevention, diagnosis, and treatment. Based on the properties and advantages of nanostructured systems, this review discusses nanomedicine strategies and possible applications that could facilitate management of the COVID-19 pandemic.

\section{Nanotechnologies in the Diagnosis of COVID-19}

Many nanomaterials have been employed in POC devices, as they have properties that are beneficial for sensing, which includes chemical stability, good electrical conductivity, and Localized Surface Plasmon Resonance (LSPR) effect (Syedmoradi et al., 2017; Kumar et al., 2019). The integrated use of nanomaterials in analytical devices could increase the sensitivity and specificity of detection systems (Zhang et al., 2020).

Gold NPs (AuNPs) are the one of the most attractive nanomaterials because they have optoelectronic properties which can be explored by different types of biosensors, in particular, those based on colorimetric, electrochemical, and plasmonic detection (Quesada-González et al., 2019; Huang Y. et al., 2020). In lateral flow assays (LFAs), for example, AuNPs have been extensively used to label the target molecule, providing a color change in the test zone, which can be read by the naked eye for qualitative results or analyzed by a smartphone that will determine the concentration of the target from a captured image (Brazaca et al., 2019). LFAs are commonly used in POC analyses to detect antibodies and proteins in complex samples such as urine, blood, and saliva. They are low-cost, provide rapid results $(5-30 \mathrm{~min})$, and can be stored at room temperature without compromising the function of biomolecules (Koczula and Gallotta, 2016). Although there are LFAs that use other labels, many studies have shown that AuNPs generate an increase in signal and sensitivity of the biosensor, which allows analyte detection at lower concentrations (Rodríguez et al., 2016; Quesada-González et al., 2019). This strategy has been employed in the diagnosis of several infectious diseases (Banerjee and
Jaiswal, 2018), including hepatitis B (Kim et al., 2016), influenza (Le et al., 2017), and Zika (Lee et al., 2016).

Recently, LFAs biosensors were applied to the diagnosis of COVID-19 and are being distributed to healthcare systems to provide decentralized testing (Udugama et al., 2020). These LFAs detect only immunoglobulin $\mathrm{G}$ (IgG) and immunoglobulin $\mathrm{M}$ (IgM) antibodies that recognize the SARS-CoV-2 proteins, which indicates that the patient was infected (Morales-Narváez and Dincer, 2020; Sheridan, 2020). Although the sensitivity is lower than the RT-PCR tests, these devices represent an important tool for screening the population (Sheridan, 2020).

In addition to LFAs, other colorimetric detection systems explore the redshift in the LSPR band of AuNPs when they aggregate. The most common detection strategy is to functionalize these nanomaterials with biomolecules, meaning that when they bind to the target molecules, the AuNPs aggregate and cause a color change in the solution (Lin et al., 2009). Moitra et al. have reported a colorimetric assay based on this latter strategy for the detection of the SARS-CoV-2 (Moitra et al., 2020). Four antisense oligonucleotides (AOs) were designed to target the $\mathrm{N}$ protein gene of SARS-CoV-2 in two different regions. The AOs were modified with a thiol group at $3^{\prime}$ or 5 ' end and conjugated to AuNPs. The hybridization between the target sequence and the AOs-capped AuNPs generated a redshift in the LSPR band of ca. $40 \mathrm{~nm}$, and the solution color changed from violet to blue (Figure 3). The specificity of the detection system was confirmed using the sequences from MERS$\mathrm{CoV}$. Importantly, this colorimetric assay is based on the optical properties of the AuNPs can significantly contribute to COVID19 management providing a fast and straightforward diagnosis.

AuNPs are also employed in electrochemical biosensors to increase the electroactive area of the electrode and the electron transfer rate, amplifying the signal (Ye et al., 2018; Zarei et al., 2018). Recently, Layqah and Eissa developed an electrochemical immunosensor for the detection of MERS-CoV using carbon electrodes modified with AuNPs (Layqah and Eissa, 2019). The biosensor is based on a competitive method in which the nasal fluid sample is mixed with antibodies against the MERS-CoV S protein and then added to the electrode where $S$ proteins were previously immobilized. After the incubation time, the electrode is washed, and a square wave voltammetry measurement is performed. When the free antibodies bind to the proteins immobilized on the electrodes, the electrical current decreases. However, when the antibodies were previously attached to MERS-CoV, the reduction in current was attenuated. The biosensor exhibited excellent analytical performance, and the low limit of detection was attributed to the deposition of AuNPs on the electrodes (Layqah and Eissa, 2019). This strategy also demonstrates the potential of AuNPs in the detection of COVID-19.

Magnetic NPs (MNPs) have also been used in biosensing devices, especially for signal amplification (Dau et al., 2019), analyte pre-concentration (Tran et al., 2018), and magnetic separation (Glynn et al., 2014). The detection of analytes directly from complex samples such as blood and urine presents some limitations, such as the low concentration of the analyte or the signal interference due to other biomolecules in the 


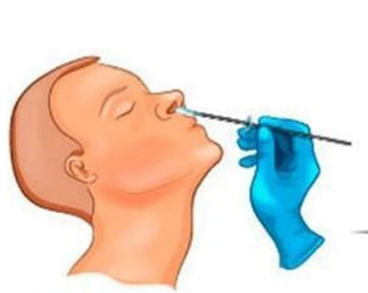

Sample Collection

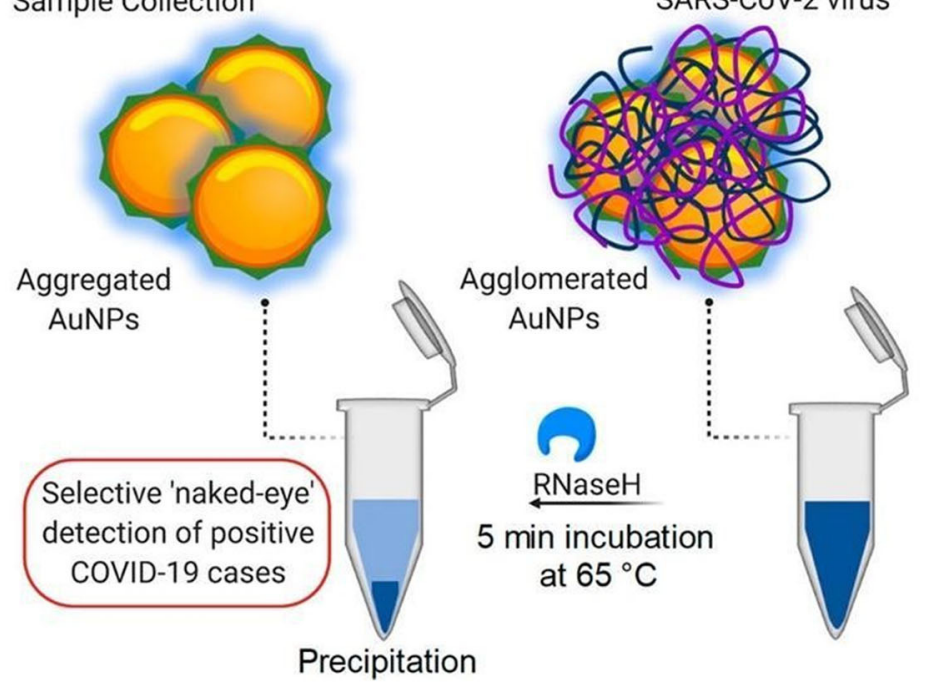

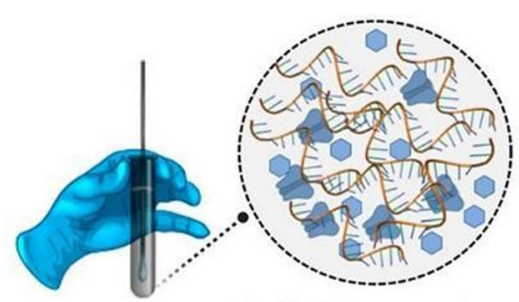

Viral RNA extraction

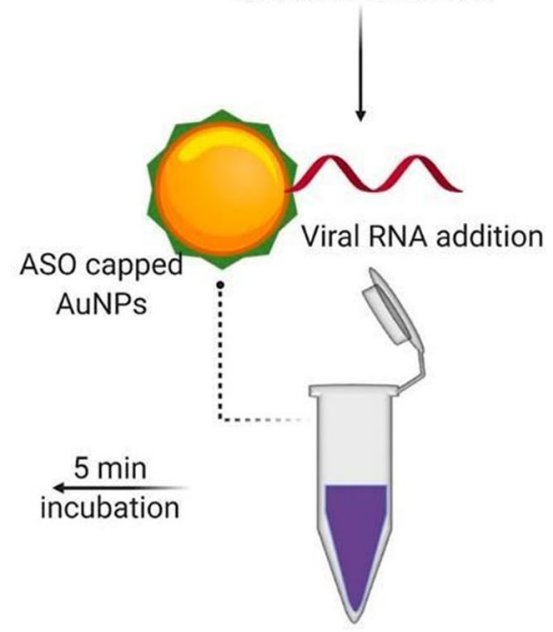

FIGURE 3 | Schematic representation of the colorimetric system using functionalized AuNPs for the detection of the SARS-CoV-2 virus (reprinted with permission from Moitra et al., 2020).

sample, which can significantly decrease the accuracy of the analysis (Zhu et al., 2020). Several studies have employed MNPs, functionalized with bioreceptors to overcome these limitations and to improve the performance of biosensors. Luo et al. have reported an electrochemiluminescence biosensor for the selective detection of the H9N2 avian influenza virus (H9N2 AIV) using MNPs modified with mAbs to capture the virus (Luo F. et al., 2020). The authors highlighted that through magnetic separation, the interference of the complex samples was decreased, and ultrasensitive detection of the virus was possible, achieving the limit of detection (LOD) of $14 \mathrm{fg} / \mathrm{mL}$ (Luo F. et al., 2020). Lu et al. employed functionalized magnetic NPs to develop a digital microfluidic chip for H1N1 virus detection (Lu et al., 2020) in which the NPs capture the virus, and electromagnetically-driven to the channels, passing through spots where they are labeled with fluorescent probes and detected. Biosensors based on magnetic NPs represent promising alternatives for the diagnosis of COVID-19.

Graphene and its derivatives, including graphene oxide (GO) and reduced graphene oxide (RGO), represent another class of nanomaterials with interesting properties for applications in biosensing. The sp2-hybridized carbon atoms arranged in a two-dimensional monolayer confer to graphene high electrical and thermal conductivity, increased surface area, and excellent chemical stability (Dau et al., 2019). These physicochemical properties can be exploited to improve the performance of biosensors, for example, by increasing the sensitivity of the system so that even lower concentrations of the analyte can be detected (Justino et al., 2017). The carboxylic groups on the surface of the oxidized graphene allow for the immobilization of biomolecules such as DNA and antibodies through covalent bonding without requiring additional functionalization steps (Hammond et al., 2016).

Graphene-based nanomaterials have been used in electrochemical and field-effect transistors (FET) biosensors. Singh et al. reported an electrochemical immunosensor integrated with a microfluidic device to detect the $\mathrm{H} 1 \mathrm{~N} 1$ virus (Singh R. et al., 2017). RGO-modified electrodes were employed to increase the sensitivity of the biosensor. The specific antibodies used to capture the virus were immobilized through a covalent bond on the RGO sheets. Using this strategy, a low detection limit of $0.5 \mathrm{PFU} / \mathrm{mL}$ was achieved. Recently, Seo et al. used graphene sheets modified with antibodies against the $S$ protein of SARS-CoV-2 to develop a FET-based biosensor for COVID-19 diagnosis (Seo et al., 2020). The performance of the biosensor was evaluated using a virus in culture medium and clinical samples, obtaining a detection limit of $1.6 \times 10^{1} \mathrm{PFU} / \mathrm{mL}$ and $2.42 \times 10^{2}$ copies/L, respectively.

These examples show how nanomaterials can contribute to the development of more accurate, sensitive, and easy-to-handle POC biosensors, in particular, for the diagnosis of viral diseases. Together with biosensing technologies, nanomaterials represent promising tools for the decentralization of COVID-19 diagnostic 
tests and for obtaining rapid results, which are crucial to quickly isolate infected patients.

\section{Nanotechnologies in the Treatment of COVID-19}

In COVID-19 therapy, nanotechnology has broad applications and can act in different stages of the disease, with the potential to inhibit virus-cell interaction, membrane fusion, cell internalization, transcription, translation, and viral replication, in addition to activating intracellular mechanisms that cause irreversible damage to viruses (Mainardes and Diedrich, 2020).

Nanoparticles (NPs) (organic and inorganic) have attracted considerable attention due to their properties. In the case of inorganic NPs (INPs), such features include luminescence, tunable size, shape, composition, large surface-volume ratio, and the ability to expose multiple interaction sites on the surface. The most commons types of inorganics NPs are mesoporous silica NPs, iron oxide NPs, and metallic NPs (gold, silver). Organic NPs are also advantageous due to the possibility of site-specific targeting of drugs, control drug release, biodegradability, biocompatibility, and non-toxicity. The most used organic NPs include polymeric and lipid-based NPs, dendrimers, extracellular vesicles (or exosomes), liposomes, and nanomicelles (Kerry et al., 2019).

Here, we highlight the potential application of nanostructured systems for the delivery of approved and repurposing antiviral drugs, which can increase treatment effectiveness through controlled release and decreased toxicity. A brief classification of the main types and an overview of the properties, synthesis, and toxicity of nanomaterials is discussed in the next section. Figure 4 summarizes possible nanostructures to be used in the therapy against SARS-CoV-2.

\section{Inorganic Nanoparticles}

INPs outstand from the others due to their optical properties. In medicine, these materials have been used as contrast agents and in photothermal therapy. The major attributes which have to lead to biomedical applications of INPs include controlled stability, enhanced permeability, high functionalization capability, and triggered controlled release (Anselmo and Mitragotri, 2019). Other properties such as luminescence, the possibility of size adjustments, shape, composition, and high surface-volume ratio show versatility for several therapeutic applications. The ability of these INPs to expose multiple surface binding sites are widely explored (Kerry et al., 2019).

In terms of clinical use, the cytotoxic properties of inorganic NPs remain an open issue. In healthy tissues, metallic NPs may induce reactive oxygen species, genotoxicity, change in cellular morphology, and cytoskeleton defects (Soenen et al., 2011). Although the conjugation of NPs with polymers or biological components aids in reducing these problems, concentration and intracellular localization could generate some side effects. For example, the acid $\mathrm{pH}$ of phagolysosomes $(\mathrm{pH} 4-5)$ produces free ions into the cytoplasm after degrading the iron surface (Mulens-Arias et al., 2020). Besides, this reduced nanostructure dimension facilitates entry into the cell nucleus and attachment to the decondensed nucleic acid streams (Soenen et al., 2011). In contrast, large particles are deposited in high vascularized organs and easily captured by macrophages. In blood, the enzymatic degradation allows it to use NPs residues (like iron and gold) in physiological metabolism, but in the lung, tissues microparticles are retained in the bronchi and nanocomposites may cluster in the alveoli, making it difficult to eliminate them from the organism before healthy cells endocytose (De Matteis, 2017).

In this section, we assess the use of AuNPs, silver NPs (AgNPs), iron oxide NPs (IONPs), and mesoporous silica (MSNPs) for viral infection therapies. Since the interaction of nanocomposites and the capsid structure from the virus can prevent its binding to the cells, surface functionalization of NPs exhibit an excellent potential for developing novel treatment agents against COVID-19 (Cagno et al., 2018).

\section{Gold Nanoparticles}

AuNPs have attracted interest in several fields of science due to features (previously described in section Nanotechnologies in the Diagnosis of COVID-19) that allow them to be applied in diagnostics and therapy. A relevant attribute is the ease of functionalization using the strong bond between gold and thiol ligands (Yang et al., 2015).

Sulfonate ligands are the most used molecules to functionalize metallic NPs because they mimic the heparan sulfate proteoglycans (HSPG) site on the cell surface. Accordingly, the virus binds to the NPs surface, blocking the infection in cells (Baram-Pinto et al., 2010). A recent study showed that AuNPs with long links of sulfonate mercaptoethanesulfonate (MES) and undecanesulfonic acid (MUS) caused irreversible deformation in several virus types, including respiratory syncytial virus, in vitro and in vivo studies. The mechanistic understanding of this interaction revealed that AuNPs functionalized with MUS present a multivalent binding to the virus, which collapses the capsid structure. Therefore, this multivalent binding could be a particularly interesting strategy for therapy in COVID-19 (Cagno et al., 2018).

In another work, Zacheo et al. showed that AuNPs functionalized with sugars with multiple sulfonate groups, especially glucose, and lactose-based ligands, showed a low effective concentration for Dengue virus. Docking experiments demonstrated that the length of the molecule that presented the best results was the one that fitted better in the $\beta$-OG pocket (Zacheo et al., 2020), suggesting that for the functionalization of AuNPs against viral infections, the length of the molecule is a crucial parameter (Cagno et al., 2018). Porous AuNPs showed a greater ability to inhibit the influenza virus compared to nonporous AuNPs and AgNPs, mainly due to the large surface area. The proposed mechanism suggests that the porous ability of AuNPs blocks the disulfide bonds in hemagglutinin, preventing the attachment in the cells (Kim et al., 2020).

Ahmed et al. reported a study using AuNPs against RNA virus. The nanosystems were used to increase the antiviral activity of ribavirin (repurposed agents for COVID-19, as seen in Table 1) loaded in AuNPs against the measles virus on the Vero cell line. The results showed a reduction of $78.1 \%$ for Vero cells treated with ribavirin-loaded AuNPs $(99.5 \mu \mathrm{g} / \mathrm{ml})$. In comparison, a reduction of only $25.4 \%$ was obtained for the cells treated 


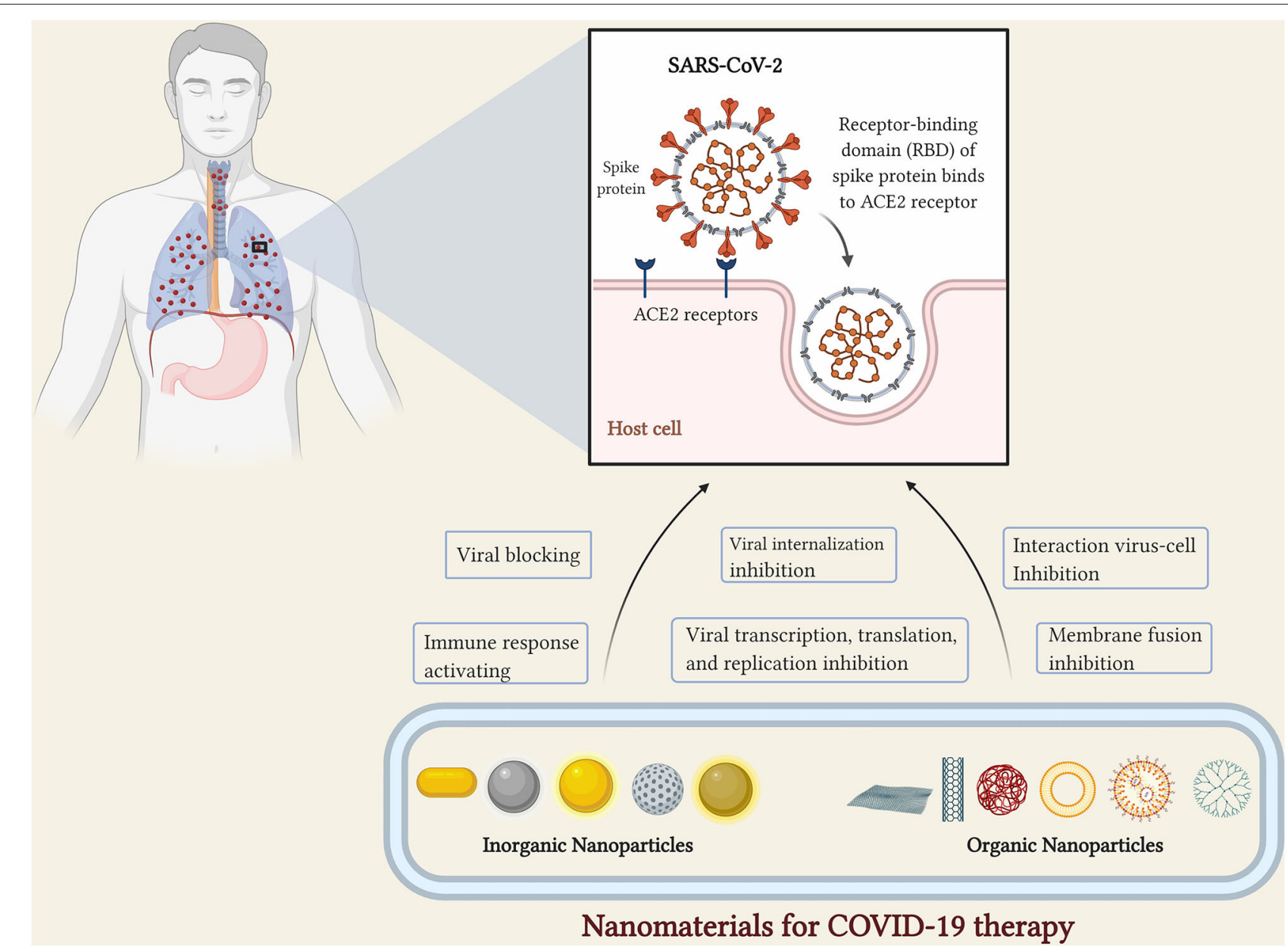

FIGURE 4 | Types of nanoparticles to application in COVID-19 therapy (figure created with BioRender.com).

with isolated ribavirin $(500 \mu \mathrm{g} / \mathrm{ml})$. The results demonstrated the ability of AuNPs to increase the antiviral activity of the drug, which represents a potential platform against SARS-CoV-2 (Ahmed et al., 2020).

The shape of a nanoparticle affects how they interact with host cells and the virus. Nanorods have attracted considerable attention due to their optical and physicochemical properties. In a recent study, a series of heptad repeat peptide 1 (HR1) inhibitors were developed to inhibit HR1/HR2-mediated membrane fusion between MERS-CoV and host cells. The results revealed that the inhibitory effects of the peptides were increased after complexing with nanorods, showing higher metabolic stability and biocompatibility in vitro and in vivo. The authors concluded that the systems effectively prevented the membrane fusion associated with MERS-CoV, demonstrating the enormous potential of the systems for the treatment of MERS in the clinic (Huang C. et al., 2020) with the possibility of COVID-19 treatment.

\section{Silver Nanoparticles}

The increased attention to the use of AgNPs has focused on antimicrobial activity, as well as optical, electrical, and thermal properties. These singular characteristics have been used widely in nanotechnology-based products (Chapman et al., 2012; Anselmo and Mitragotri, 2015). The main advantage of AgNPs is the possibility that they could be used as antiviral agents without surface modifications. A study showed that naked AgNPs (with a diameter of $55 \mathrm{~nm}$ ) have demonstrated inhibitory actions against the Monkeypox Virus (MPV), preventing virus internalization (Rogers et al., 2008). This antiviral property relies on three possible mechanisms: AgNPs might attach to glycoproteins on the virus surface, be internalized by the cells, and block genome replication, attaching to the cell membrane surface and preventing virus fusion (Rai et al., 2016). However, the application of naked AgNPs has limitations regarding the intrinsic cytotoxicity they exhibit. To overcome these limitations, polyvinyl alcohol (PVA) and polyvinylpyrrolidone (PVP) can be used as coating materials (Elbaz et al., 2016). Lara et al. showed that PVP coated AgNPs $(30-50 \mathrm{~nm})$ had antiviral activity on human immunodeficiency virus (HIV-1) strains. This early-stage effect occurs due to the binding of NPs in GP120 (glycoprotein exposed on the surface of the HIV envelope) on the virus, preventing fusion in the CD4 cell receptors (Lara et al., 2010). 
Curcumin functionalized AgNPs also showed high antiviral properties for Respiratory Syncytial Virus (RSV), and no cytotoxicity was observed after incubation with cells. The proposed mechanism is the inactivation of the virus before the interaction with cells (Yang et al., 2016). Morris et al. demonstrated the PVP AgNPs antiviral activity for RSV, using $10 \mathrm{~nm}$ particles at a concentration that exhibited a robust antiviral behavior but no cytotoxicity for epithelial cells (Morris et al., 2019).

\section{Iron Oxide Nanoparticles}

IONPs are widely used for biomedical applications, mainly as contrast agents for magnetic resonance imaging. Due to their biocompatibility, there are several IONPs-based products approved by the FDA (Anselmo and Mitragotri, 2019). The magnetic characteristics of IONPs are related to the superparamagnetic behavior of small NPs that appear in response to an external magnetic field (Williams and Corr, 2013).

This antiviral activity relies on surface modification with sulfonates or other molecules. Bromberg et al. (2012) synthesized core-shell silica-magnetic NPs functionalized with poly(hexamethylene biguanide) (PHMBG). The authors reported that NPs exhibited a notable virucidal effect on several virus strains, which occurred via amino alkylation of their genomic materials, blocking genome replication and leading to viral inactivation (Bromberg et al., 2012).

Mannose-loaded IONPs were developed for delivery in dendritic cells (DC). A significant increase in the expression of IL-6, TNF- $\alpha$, and IFN- $\gamma$ was observed in the DCs compared to IONPs without mannose in vitro studies. In vivo studies also showed higher levels of TNF- $\alpha$, IL-2, IL-4, IL-12, and INF- $\gamma$ using mannose-loaded IONPs (Rezaei et al., 2019).

More attention must be given to IONPs, considering the iron dysregulation in COVID-19. Recent studies have suggested that interactions between SARS-CoV-2 and hemoglobin (and other receptors) occur in the erythrocyte or red blood cell precursors, resulting in the hemoglobin denaturation and iron metabolism dysregulation. Iron overload in tissues is a major concern (Cavezzi et al., 2020). Some papers have shown higher levels of ferritin and lower hemoglobin levels in patients that did not survive (Liu and Li, 2020; Zhou et al., 2020). These iron level changes can reduce the use of these NPs in clinical applications since they might lead to side effects (Bisso and Leroux, 2020).

\section{Mesoporous Silica Nanoparticles}

Mesoporous silica NPs (MSNPs) have tunable size pores that allow accommodating molecules inside and outside for codelivery. These dual characteristics could provide an excellent platform to treat COVID-19 if they can be functionalized with several ligands to inactivate the entry of the virus in the host cell and to the site-specific release of these ligands, preventing viral replication. Lee et al. have reported on the dual delivery features of MSNPs for antiviral applications. Acyclovir-loaded MSNPs (coated with glycosaminoglycan) were used to inhibit the entry of HSV-1 and HSV-2 (herpes simplex virus types). The results showed that NPs act in the early stages of viral internalization and DNA replication simultaneously (Lee E. C. et al., 2018).
Lipid-coated MSNPs containing the antiviral (E)-2(1,4-Dimethylpiperazin-2-ylidene)amino)-5-nitro-N-phenyl benzamide (ML336) were developed as a strategy to improve antiviral circulation time and biocompatibility. Although nanosystems have shown a virucidal effect in the Venezuelan equine encephalitis virus, low stability and solubility mean that they have limited clinical uses. In vitro results have revealed a dose-dependent virus inhibition and an additional ML336 release after cell endocytosis, while the in vivo results showed that the NPs demonstrated significate antiviral activity and no toxicity (LaBauve et al., 2018).

\section{Organic Nanoparticles}

\section{Carbon Nanotubes and Graphene Nanoparticles}

Carbon-based nanomaterials such as carbon nanotubes (CNTs), graphenes, and fullerenes NPs present interesting physicochemical properties for innovative scientific and technological applications (Comparetti et al., 2018). CNTs have covalent bonds $\left(\mathrm{sp}^{2}+\mathrm{sp}^{3}\right.$ hybrid phases) and excellent electric conductivity, enabling their use in different research fields. Single wall carbon nanotubes (SWCNT) and multi-wall carbon nanotubes (MWCNT) are folded graphene sheets with a diameter of $5-20 \mathrm{~nm}$, and a length ranging from 50 to $1,000 \mathrm{~nm}$ (Rashid and Ralph, 2017).

As a perspective for COVID-19 treatment, CNTs exhibit limitations in terms of toxicity (Alidori et al., 2016). When exposed to the lungs they activate macrophages in the lower respiratory tract, inducing fibrosis, and the formation of collagen in the lesions (Mangum et al., 2006). Moreover, it was already demonstrated that CNTs are spontaneously internalized by lung cells via binding with the epidermal growth factor (EGF) receptor (Luanpitpong et al., 2014). In vitro studies also demonstrated an enhancement of influenza H1N1 virus infectivity in lung epithelial cells after intranasal administration of CNTs (Sanpui et al., 2014). The functionalization of CNTs may be a promising strategy to overcome these disadvantages. Hussain et al. demonstrated that the inflammatory processes significantly reduce when biomolecules (proteins and polymers) were conjugated on the CNTs surface, decreasing cytotoxicity in the respiratory system (Hussain et al., 2016).

The functionalization of CNTs with hyaluronic acid increases the interaction of nanosystems with bronchial cells and prevents the inflammatory process in the pulmonary tissues since they are not captured by alveolar macrophages (Hussain et al., 2016). These results corroborate the fact that CNTs modification with cellular ligands increases NPs uptake and drug release at targeted tissues by endocytic absorption without plasmatic membrane damages (Maruyama et al., 2015; Hussain et al., 2016). Wang et al. also succeeded in increasing single-wall carbon nanotubes (SWCNTs) specificity to lung cell receptors after conjugation with anti-CTLA-4 antibodies. Besides, CNTs and graphene quantum dots functionalized with antiretroviral drugs (CHI360, CHI415, CHI499, and CDF119) were able to inhibit reverse transcriptase enzyme activity in lymphocytes of HIV-positive patients (Iannazzo et al., 2015, 2018). These strategies may be interesting for future treatments against COVID-19 because NPs 
could improve the effectiveness of therapeutic agents, speedingup the delivery of drugs to diseased cells. Although it is possible to reduce immune cell activation and the inflammation processes using carbon NPs, the application of them in therapy is not recommended.

\section{Polymeric Nanoparticles}

Currently, there are several products based on biodegradable polymers approved by the FDA and European Medicines Agency (EMA), used in the development of NPs for delivery of new antiviral molecules. Polymeric NPs are promising materials to be used against viral diseases since they can be engineered to reach specific targets (extracellular or intracellular) and block virus attachment to host cell receptors. These characteristics are essential to control viral diseases, as well as to reduce adverse effects (Singh L. et al., 2017), improving the safety of the antiviral drugs and overcoming the cellular drug resistance (Lembo et al., 2018).

The delivery of active molecules using NPs has been proven efficient in inhibiting virus replication (Lee E. C. et al., 2018). For example, nanocarriers based on a $\beta$-cyclodextrin-poly $(4-$ acryloylmorpholine) mono-conjugate $(\beta C D-P A C M)$ polymer functionalized with guanine analogs (acyclovir) were capable of reducing extracellular virus uptake (Cavalli et al., 2009). Studies already demonstrate the effectiveness of acyclovir delivery using NPs, enhancing the blockage of DNA replication at herpes virus-infected cells (Lee E. C. et al., 2018). Also, poly(ethylene glycol)- poly(lactic-co-glycolic acid) (PEG)-PLGA) diblock copolymers have been studied to coupling two ATPase inhibitors (dyphylline and bafilomycin) for antiviral activity. The intravenous administration of PLGA nanocarriers improved the anti-influenza applicability of dyphylline in H1N1 infection, exhibiting controlled drug release in the lungs and providing significant protection against lethal doses of the virus in vitro and in vivo models (Hu et al., 2018).

Ge et al. used polyethyleneimine (PEI) NPs loaded with siRNA and demonstrated the ability of the NPs to inhibit influenza virus replication from a conserved genetic locus linked to virus susceptibility. PEI complexes are efficient siRNA carriers into the lungs, able to reduce 1,000-fold virus infection than other oligonucleotides encoding vectors (Ge et al., 2004; Beyerle et al., 2011). Although the high concentration of PEI for drug delivery is not indicated, PEG modification improves particle hydrophobicity with less pro-inflammatory responses and no cytotoxic side effects in healthy tissues (Beyerle et al., 2011). To optimize safe formulations, NPs PEGylation prevents classical macrophages activation and the elimination from the lungs for at least 1 month (Shen et al., 2015).

Other strategies for polymeric NPs have been proposed, which suggest replacing molecules and mAbs to block virus uptake in host cells. As a perspective, these NPs could be used to inhibit the interaction between SARS-CoV-2 and $\mathrm{ACE} 2$, preventing the infection of the virus in human tissues. Henning et al. reported the use of polymeric structures (branched-PEG molecules and polyamidoamine (PAMAM)dendrimers NPs) to bind angiotensin receptors and act as antagonist agents along with viral infection (Hennig et al., 2015).
Similarly, angiotensin ligands-loaded copolymer structures bind to angiotensin enzymes, ensuring treatment specificity in ACE2 ${ }^{+}$ cells for future drug delivery studies (Figueroa et al., 2019). Therefore, the ability of NPs to prevent viral binding at ACE2 appears to be promising against $\mathrm{CoVs}$ infection.

To treat respiratory diseases, therapeutic strategies in nanomedicines have taken into account the promising results coming from administration by inhalation. Mouth and nasal routes require nanostructures with diverse functionalities to cross biological barriers in highly vascularized tissues for depositing drugs into targeted sites. Polymeric structures or polymer-based NPs are indicated to pulmonary systemic absorption, exhibiting lower cytotoxic effects to healthy cells than inorganic NPs (Ajdary et al., 2018).

The main administration methods responsible for delivering particles on the respiratory tract are jet nebulizers, pressurized metered-dose inhalers, dry powder inhalers, and soft-mist inhalers. These strategies deposit structures with a size between 10 and $5,000 \mathrm{~nm}$ in pulmonary tissues by Gravitational Sedimentation $(0.5-5 \mu \mathrm{m})$, Brownian Diffusion $(<0.5 \mu \mathrm{m})$, Electrostatic Precipitation, and Interception (Kaur et al., 2012; Muralidharan et al., 2015). The biocompatibility and low toxicity of polymeric NPs make them highly promising for treating respiratory diseases through inhalation. Moreover, the properties of mucoadhesives allow for the crossing of biological barriers in pulmonary systemic absorption (Ajdary et al., 2018). In vivo, microparticles loaded with bronchodilators have low efficiency than conventional methods (Lai et al., 1993). However, corticosteroids-loaded polymeric NPs used to treat asthma, and chronic obstructive pulmonary illness exhibited deep penetration in the lung by aerosol administering (Singh et al., 2019).

Nanocomposites have limitations in inhalation therapy because they decompose in the respiratory system, have drug resistance, and involve a periodic structural mutation in infectious organisms. Polymeric NPs are promising materials for such applications, due to their improved biocompatibility. The nanocarriers have been widely studied to induce higher antiviral activity against respiratory infectious than the administration of anti-virus alone. For example, as a novel vaccine strategy, NPs were used to deliver influenza virus antigens intended to reeducate the cellular inflammatory profile. The intranasal delivery of chitosan NPs induces a controlled release of H1N1 proteins for macrophages activation, followed by an adaptative immune response to the virus infection (Liu et al., 2015).

In the COVID-19 patients, the infection leads to severe expression of inflammatory cytokines by activated immune cells (Hirano and Murakami, 2020). Due to the intense phagocytosis performed by white blood cells, nebulization of PLGA NPs coated with chitosan were able to cease the migration of eosinophils and neutrophils in the lungs, preventing severe biological dysfunctions (Aragao-Santiago et al., 2016). Nanostructures loaded with anti-inflammatory drugs reduce the generation of intracellular reactive oxygen species (ROS) in the pulmonary epithelium and avoid the expression of IL- 6 and chemokine MIP2 by alveolar macrophages (Yoo et al., 2013; Shen et al., 2015). Another strategy to neutralize pro-inflammatory cytokines uses anti-IL-6 antibodies immobilized on chitosan NPs to remove 
such molecules from diseased tissues. To avoid organ failure, this approach prolongs mAbs activity (in comparison to the free isoform), trapping cytokines in the inflammatory region (Lima et al., 2018), which addresses the cytokine release syndrome (CRS) caused by SARS-CoV-2.

Polymeric NPs can also be used as adjuvant therapies, collecting and eliminating cytotoxic molecules from the human body. Like antiviral agents, NPs can be designed to attach viral proteins, decreasing disease infectivity. Recently, Bawa et al. showed that polymer-coated NPs can be used to trap and destroy viral particles (Bawa et al., 2016). Nanoviricides (NanoViricides Inc.) binds to multiple virus receptors and neutralize organism replication after avoiding cell internalization. NPs functionalized with targeting proteins increase the affinity and specificity to the desired virus and, upon simple modifications, may provide a fast therapeutic platform to treat new diseases. Their conjugation with undecanesulfonic acid (MUS) aids them to recognize and induce an irreversible structural deformation in respiratory viruses, inhibiting binding to the extracellular matrix of eukaryotic cells (Cagno et al., 2018).

Currently, therapies with methotrexate (MTX)-loaded NPs had been approved in Brazil for phase I and II clinical trials (NCT04352465). This study aims to evaluate the effectiveness and safety of the MTX-loaded NPs in severe inflammatory reactions, which could result in acute lung injury during the treatment of COVID-19 patients. Multi-functional polymeric nanocarriers had been approved as novel nanoplatforms for clinical application and could be immediately updated for safe use in the current SARS-CoV-2 pandemic (U.S. National Library of Medicine, 2020).

\section{Dendrimers}

Dendrimers represent a revolution in nanotechnology as novel nanocarriers able to improve the efficiency of drugs and bioactive compounds. Structurally, the dendrimers are radially symmetric macromolecules with homogenous, welldefined, and highly branched three-dimensional structures that present compact globular structures. Unique physicochemical properties, such as solubility, low polydispersity, effective drugencapsulation capacity (Lembo et al., 2018), biodegradability, and biocompatibility mean that they are useful in encapsulating hydrophobic therapeutic agents (Li and De Clercq, 2020). The ability of dendrimers to establish strong interactions with viruses may increase antiviral activity, making them promising systems against viral infections (Kim et al., 2018; Lembo et al., 2018; Itani et al., 2020).

Dendrimers have been widely studied for applications against HIV infection. The systems are engineered with specific functional end groups able to interact preferentially with the $\mathrm{E}$ protein of HIV and host cell receptors and, consequently, to suppress viral replication (Mhlwatika and Aderibigbe, 2018). One example of a dendrimer that is commercially available is SPL7013 Gel (VivaGel ${ }^{\circledR}$ ), a type of microbicide dendrimer comprising a divalent benzhydryl amine (BHA) core, four generations of lysine branches with the outermost branches capped with a total of 32 naphthalene di-sulfonic acid groups, developed for the prevention of HIV and HSV infections. The clinical effectiveness of SPL7013 Gel as a topical vaginal microbicide has already been demonstrated (Price et al., 2011; Kim et al., 2018).

The first pilot study employed polycationic dendrimers (generations 2-5) based on primary amine to assess in vitro antiviral activity against the MERS-CoV. It was evaluated the effect of dendrimer size and terminal charge on the ability of MERS-CoV to produce viral plaques in infected Vero cells. The results demonstrated that polyanionic dendrimers can be successfully used in drug delivery, improving antiviral activity (Kandeel and Al-Nazawi, 2020). To date, no studies have used dendrimers against SARS-CoV-2, however, the potential of dendrimers for application in the treatment of viral infections has been demonstrated (Mhlwatika and Aderibigbe, 2018), suggesting it as an interesting potential approach in the fight against COVID-19.

\section{Lipid-Based Nanoparticles}

Lipid-based NPs have great potential to translate into clinical contexts of COVID-19 because they biodegrade and have promising biocompatibility (Puri et al., 2009). Several lipidbased formulations have already been successfully adapted into a marketed drug product (e.g., Doxil, AmBisome). Different types of lipid raw materials can be employed in the development of nanocarriers such as phospholipids, fatty acids, mono-, di- and triglycerides, waxes, and oils, which assemble in water in different structured systems due to their hydrophobic and amphiphilic nature. The resulting particles share some similarities with biological components such as cell membranes and the pulmonary surfactant biomembrane system (Kulkarni, 2012). For this reason, the toxicity of lipid nanoparticles is lower compared with other types of nanomaterials. Lipid-based NPs have already been explored for the treatment of HIV, herpes, and hepatitis $\mathrm{B}(\mathrm{HBV})$ and $\mathrm{C}(\mathrm{HCV})$ viruses because they can encapsulate different classes of antiviral drugs, mediating the delivery from the administration site to the target and modulating specific biological responses (Pollock et al., 2010; Jain et al., 2011; Shah et al., 2017).

Liposomes are bilayered structures extensively investigated as nanomedicine platforms for drug delivery. They are mainly composed of synthetic or natural phospholipids (e.g., phosphatidylcholine, phosphatidylserine), cholesterol, and sphingolipids (Akbarzadeh et al., 2013). The existence of hydrophobic layers and aqueous compartments in the vesicular assembly makes these nanocarriers suitable for the encapsulation of lipophilic and hydrophilic molecules. Liposome-based carriers have also been used for encapsulation of antiviral to be used in the treatment of infected cells, due to their ability to promote intracellular delivery of different types of drugs (Clayton et al., 2009; Pollock et al., 2010; Croci et al., 2016). Furthermore, the lipid composition affects the infectivity of cells. Kolyvushku et al. reported that cationic and anionic liposomes interact with equine herpesvirus type 1 (EHV-1) inhibiting infection. The authors of this study attributed this response to the charged phospholipids 1,2-dioleoyloxy-3-(trimethylammonium)propane (DOTAP) and phosphatidylserine, once the neutral phosphatidylcholine was not able to modulate the virus entry in cells to inhibit infection (Kolyvushko et al., 2020). In another study, Pollock 
et al. showed that polyunsaturated liposomes had high antiviral inhibition against three viral types: HBV, HCV, and HIV. The study demonstrated that a reduced infection was dependent on the cellular and virus associated-cholesterol levels (Pollock et al., 2010).

Surface-modified liposomes increase the potential of the nanocarriers toward a more precise nanomedicine platform. Hydrophilic polymers, proteins, and mAbs are commonly used in liposome functionalization. For example, the use of hydrophilic PEG minimizes unspecific cellular uptake. PEGylated liposomes have increased stability and longer circulation times and also improved targeting immunological attributes (Mohamed et al., 2019). Recently, it was demonstrated that the PEGylation of liposomes resulted in macrophage uptake independent of protein corona formation (Weber et al., 2019). This strategy is particularly interesting in the context of COVID-19 therapy because alveolar macrophages remove particles in the respiratory surface, which could hinder the therapeutic effects on pneumocytes. Regarding protein or mAb functionalization, it was reported that this strategy could add specificity to the nanocarriers toward viral proteins (Eloy et al., 2017). Furthermore, these targeted liposomes have improved cellular uptake, which can be explored for modulating antiviral responses in infected cells. Following this research line, Clayton et al. reported that liposomes that were carrying the PI1 protease inhibitor, functionalized with PEG and an HIV-directed $\mathrm{mAb}$ fragment, promoted a sustained and specific inhibition of HIV-1 replication (Clayton et al., 2009).

Liquid crystalline NPs (LCNPs) are non-lamellar selfassembled systems formed by polar lipids such as Phytantriol (PHYT) and Glyceryl Monooleate (GMO) (Azmi et al., 2015). This class of nanocarriers has received attention as they can accommodate small and large molecules and imaging agents in their nano compartments (Zhai et al., 2019). LCNPs have a diverse phase behavior ranging from cubic (cubosomes) to inverted hexagonal nanostructures (hexosomes) (Rodrigues et al., 2016; Barriga et al., 2019). The lipid supramolecular arrangement of LCNP with water channels interpenetrated networks in the structure that make them a suitable host for hydrophilic and hydrophobic drugs (Azmi et al., 2015). The non-lamellar morphology confers distinct biological interactions to the LCNPs. For example, it has been demonstrated that cellular uptake of hexosomes is independent of endocytosis, the most common mechanism for liposome uptake. Additionally, the internalization of hexosomes seems to be dependent on the degree of cell membrane tension: lower tension leads to higher internalization. This feature makes this class of lipidbased nanocarriers interesting for infectious diseases in which the biophysical properties of cellular membranes are somewhat altered (Rodrigues et al., 2019).

It has been reported that LCNPs could be potential drug delivery carriers due to their sustained release capacity in comparison with other nanocarriers (Karami and Hamidi, 2016). Cubosomes favor the absorption of poorly soluble drugs in the intestines due to their sustained action. However, this effect was dependent on the internal structure of the LCNPs: GMO-based cubosomes did not sustain the absorption of the drug at the same level as PHYT-based ones. The differences in the behavior of the main polar lipid that generates the liquid crystalline phase and the addition of saturated fatty acids (e.g., lauric, myristic, stearic, etc.) affect the drug release behavior (Thapa et al., 2013). Furthermore, the addition of fatty acids into the formulation confers to the particles a pH-triggering response (Tran et al., 2015; Mertins et al., 2020). The latter can be exploited in the inflammatory conditions present in SARS-CoV-2 infection due to alterations in the alveolar $\mathrm{pH}$ microenvironment. Therefore, it is crucial to optimize composition factors toward the control of the lipid supramolecular arrangement in LCNPs to achieve the desired action (Huang and Gui, 2018).

Microemulsions (ME) and nanoemulsions (NE) are two similar systems composed primarily of water $(\mathrm{W})$, oil $(\mathrm{O})$, and surfactant (S) assembled in nanodroplets. Unconventionally, the main difference between these two lipid-based systems is not related to the range of particle sizes but their physicochemical stability. While ME are formed spontaneously by mixing the components and present thermodynamic stability, NE are fabricated using an energy input, and they are thermodynamic unstable, though they exhibit kinetic stability (McClements, 2012). These physicochemical characteristics make ME susceptible to dilution procedures, which can be interesting for fabricating systems with stimuli-responsive properties triggered by contacting biological fluids. The dynamic nature of ME self-assembly is explored by self-microemulsifying drug delivery systems (SMEDDS) aiming at improving the bioavailability of poorly soluble drugs by the oral route (Gursoy and Benita, 2004; Deshmukh et al., 2019).

On the other hand, NE droplets are stable during dilution, which is interesting for parenteral applications. ME and NE can accommodate both lipo- and hydrophilic substances as the components can self-organize in oil-in-water $(\mathrm{O} / \mathrm{W})$ or water-in-oil (W/O) structures. Both systems have already been explored as vehicles for vaccines and antiviral therapies (Bernstein et al., 2019).

Solid lipid NPs (SLNs) and nanostructured lipid carriers (NLCs) are relatively new nanosystems based on solid lipids or a combination of solid and liquid lipids, respectively. The hybrid nature of NLCs brings some advantages over the SLNs, such as the control of crystallinity degree, an essential factor to be considered for drug loading (Ganesan and Narayanasamy, 2017). Despite this physicochemical difference, both systems have been used for the delivery of poorly soluble drugs by different routes of administration (Khosa et al., 2018). It has been reported that SLNs can be used to achieve the alveolar macrophages, a type of cell involved in pulmonary infectious diseases such as COVID-19 (Chuan et al., 2013). Repeated inhalation of SLNs was demonstrated to be safe in a murine model (Nassimi et al., 2010), and their clearance was shown to be similar to conventional liposomes (Haque et al., 2018).

\section{Nanotechnologies in the Prevention of COVID-19 Environment and Surface Cleaning and Health Care Antiseptics}

Several products use nanomaterials with antimicrobial activity for disinfection. One of these, CAC-717, is a product containing 
mesostructured NPs with effectiveness at inactivating enveloped (Nakashima et al., 2017) and non-enveloped viruses (Sakudo et al., 2020). Tungsten carbide NPs are also promising methods of disinfection due to their broad virucidal activity (Pfaff et al., 2019).

Another strategy in the prevention of the spread of COVID19 could involve creating self-disinfecting surfaces that are coated with nanomaterials such as silver, zinc oxide, and copper NPs, which oxidize and release ions with antimicrobial properties (Murphy et al., 2020; Weiss et al., 2020). For example, AgNPs are already widely used as a disinfectant with biomedical, environmental, and industrial applications (Deshmukh et al., 2019). They have antiviral activity against several types of viruses such as respiratory syncytial, HBV, and HIV (Galdiero et al., 2011), and can also be used in air filter materials (Deshmukh et al., 2019) and clothing fabrics (Noor et al., 2019).

Disinfection can also be performed by UV light-activated photosensitizers, which use nanosized titanium dioxide $\left(\mathrm{TiO}_{2}\right)$ to disinfect indoor environments, such as hospitals and clinics (Nakano et al., 2012; Boyce, 2016; Murphy et al., 2020). The effect of $\mathrm{TiO}_{2} \mathrm{NPs}$ on the influenza virus was evaluated by Mazurkova et al. (2010) and the results revealed that virus inactivation was dependent on the NPs concentration and the incubation period.

In addition to procedures for cleaning surfaces, the adoption of adequate personal and interpersonal hygiene practices, such as hand washing and care when sneezing and coughing, are essential to reduce the spread rate of COVID-19. An excellent option for hand hygiene is the AgNPs gel recently described for Ahmed et al. (2019). Researchers from Shri Shiv Chhatrapati College have also used a nanometal compound and an aromatic medicinal herb in a handwash formulation (eco-friendly and non-toxic for humans) with antiviral and antibacterial properties that can also be used for washing clothes (Joshi, 2020).

Graphene is another important nanomaterial with significant antimicrobial and antiviral activity. The ability to promote the steric impediment of bacterial, viruses, and other molecular agents, allows graphene to be used as a photoactivated agent or as a heat generator to sterilize fabrics and filters (Palmieri and Papi, 2020). Since coronavirus survives for up to about $3 \mathrm{~h}$ suspended in the environment, nanocomposites can also be used in air purifier devices to trap floating particles, preventing the spread of the virus in public and private spaces. Currently, carbon NPs-based membrane filters remove and destroy pathogens in the air and the water (Table 2). It was already demonstrated that CNTs and graphene sheets attach viral membrane by hydrogen bonds and electrostatic forces, entrapping infection agents and inactivating them by compression in carbon-based fibers (BradyEstévez et al., 2010; Song et al., 2015; Rashid and Ralph, 2017).

New elements have been tested to fabricate multifunctional devices that can remove contaminants from the air, including silicone, glass, alumina ceramics, and cellulose substrates. These have been superficially modified with nanostructures to capture pathogens by direct interception, Brownian diffusion, inertia impact, sedimentation, and electrostatic forces (Viswanathan et al., 2004; Zhao et al., 2005; Park and Hwang, 2014; Rashid and Ralph, 2017). In controlled conditions, Yeh et al. incorporated CNTs on a silicon surface to increase flu virus retention.
Negatively charged MWCNTs (with length ranging from 10 to $1,000 \mathrm{~nm}$ ) interact with bacteria and viruses by covalent bond, resulting in a filtration efficiency of $92 \%$ (Park and Hwang, 2014; Yeh et al., 2016). Although alumina ceramics membrane containing MWCNTs retain particles with diameters above $300 \mathrm{~nm}$, polyethylene terephthalate (PET) conjugated with SWCNTs retained particle with a diameter between 11 and $650 \mathrm{~nm}$ (Nasibulin et al., 2011; Zhao et al., 2015). A single sheet of carbon nanotubes increases the filter thickness by $40 \mathrm{~nm}$, but air purification efficiency is increased to $99.9 \%$ (Nasibulin et al., 2011).

\section{Personal Protective Equipment (PPEs)}

The use of protectives clothes, face masks, and respirators are essential for self-protection in vulnerable populations, who include infected patients, the elderly, immunocompromised individuals, and health professionals (Srivastava and Saxena, 2020). Several types of nanomaterials can be used in the development of more efficient filtration face masks and respirators, or to apply antimicrobial properties in personal protective equipment (PPEs). N95 respirators are well-known and, typically, used for high-risk situations (Chughtai et al., 2013). With a pore size of around $300 \mathrm{~nm}$, N95 shows $85 \%$ efficiency for filtration of sub- $300 \mathrm{~nm}$ particles, which is favorable to avoid contamination by SARS-CoV-2 (Bar-On et al., 2020). The use of disposable flexible nanoporous silicon-based membranes may improve the efficiency of N95 respirators since a filtering efficiency enhancement is obtained (pores down to $5 \mathrm{~nm}$ ). Moreover, the reusability of the N95 face masks could be a strategy to minimize the problems related to the shortages of single-use face masks (El-Atab et al., 2020).

In a recent study, $\mathrm{Si}$ et al. developed green bioprotective nanofiber membranes with refillable antibacterial and antiviral activities, which were capable of producing biocidal reactive oxygen species when exposed to daylight. The membranes showed a high capacity to block fine particles $(>99 \%)$, in addition to having high bactericidal ( $>99.999 \%$ ), and virucidal (>99.999\%) activities (Si et al., 2018). These results show that the use of nanostructured membranes could prevent the high spread of SARS-CoV-2. Nanofibers are also promising as filter materials for face masks and clothing (Ramakrishna et al., 2006; Akduman and Akcakoca Kumbasar, 2018). Some examples are $\mathrm{TiO}_{2}$-coated nanofibers for the capture and destruction of viruses by UV radiation or natural sunlight (Weiss et al., 2020); electrospun nanofibers with the ability to retain aerosol particles with sizes from 20 to $200 \mathrm{~nm}$ (filtration efficiency over $99 \%$ for the thicker layer) (Faccini et al., 2012), and nylon-silver composite nanofibers (Francis et al., 2010; Montazer and Malekzadeh, 2012). Recently, the development of new reusable nano-filtered face masks containing nanofibers (diameter ranging from 100 to $500 \mathrm{~nm}$ ) was announced by the research team at the Korea Advanced Institute of Science and Technology (KAIST). These face masks can be washed more than 20 times, without causing deformation in the nanomembrane structure (Kim, 2020).

Other attractive nanomaterials for filters, face masks, and protective clothing, are copper iodide NPs (Fujimori et al., 2012) and AgNPs (Galdiero et al., 2011). Zhong et al. have developed 
TABLE 2 | Some types of carbon nanofillers used to remove viruses of air and water.

\begin{tabular}{|c|c|c|c|}
\hline NPs types & Function & Target & References \\
\hline Fullerene & Photosensitisers & Inactivation of viruses in biological fluids. & Käsermann and Kempf, 1998 \\
\hline Graphene sheets & Air Filter & Virulence factors. & Stanford et al., 2019 \\
\hline SWCNTS & Water filter & Escherichia virus MS2 & Brady-Estévez et al., 2010 \\
\hline \multirow[t]{2}{*}{ MWCNTS } & Air virus capture and detection & Influenza A virus subtype H5N2 and H7N2 & Yeh et al., 2016, 2020 \\
\hline & Air filter & Escherichia virus MS2 & Park and Hwang, 2014 \\
\hline
\end{tabular}

reusable graphene oxide face masks with super-hydrophobic properties able to improve protection performance. The products can be submitted to sunlight sterilization and recycled for desalination (Zhong et al., 2020). Additionally, after the COVID19 outbreak, a silver nanocluster/silica composite coating was tested and showed a virucidal effect, reducing the SARS-CoV-2 titer to zero, under test conditions. This coating can be deposited on filtering media and ceramic, metallic, glass, and polymeric surfaces (Balagna et al., 2020). All these nanosystems show high potential for application against SARS-CoV-2.

\section{Vaccines}

Prophylactic vaccination is one of the most important, cheapest, and effective forms of health intervention. It is responsible for the control or the near eradication of many diseases, such as smallpox, polio, and measles (Nasrollahzadeh et al., 2020). According to the WHO, immunization prevents 23 million deaths per year in all age groups (World Health Organization, 2020b). Since the genetic sequence of SARSCoV-2 was identified, a global race for a vaccine has started (Le et al., 2020), and 156 clinical vaccine development trials were registered when this review was written. Among them are RNA vaccines (NCT04368728), artificial antigen-presenting cell vaccine (NCT04299724), synthetic mini-gene vaccine (NCT04276896), recombinant novel CoV vaccine-Adenovirus type 5 vector (NCT04313127), and autologous dendritic cells loaded with antigens from SARS CoV-2 (NCT04386252) (U.S. National Library of Medicine, 2020).

Nanotechnology represents an excellent tool for vaccine development. It can be beneficial for antigen protection from premature degradation to enhance immunity response, control release kinetics, reduce adverse effects, deliver site-specific antigens, and facilitate intracellular uptakes (Zaman et al., 2013; Chen et al., 2017; Nasrollahzadeh et al., 2020; Poon and Patel, 2020). There are currently many commercially available nanotechnology-based vaccines, such as Gardasil ${ }^{\mathrm{TM}}$, Cervarix $^{\mathrm{TM}}$, Inflexal ${ }^{\circledR}$ V, and Epaxal ${ }^{\circledR}$ (Chen et al., 2017).

Organic NPs gained traction concerning vaccine formulations due to the promising properties. Organic NPs have been used successfully in vaccine development, such as liposomes, lipidbased NPs, and polymeric NPs. Liposomes are the most used nanoparticles with clinically approved products for hepatitis A, and influenza A and B (Poon and Patel, 2020). Lipid-based NPs were previously used for the intradermal administration of mRNA for MERS-CoV S proteins, demonstrating significant humoral immune responses (Liu et al., 2020). Among the polymeric NPs, we can cite chitosan NPs for nasal SARS-CoV DNA immunization against SARS-CoV (Raghuwanshi et al., 2012) and PEI NPs, which are used for SARS-CoV plasmid DNA nasal vaccination (Shim et al., 2010).

Biopolymer-based NPs, such as protein-based NPs, are also attractive due to their low toxicity and biodegradability (Lohcharoenkal et al., 2014). SARS-CoV S protein NPs were used as a vaccine and induced antibody production in mice, especially when combined with Matrix M1 adjuvant. The NPs, with diameters of ca. $25 \mathrm{~nm}$, were formed by the $S$ trimers during protein purification (Coleman et al., 2014).

Virus-like proteins (VLPs) also have advantageous properties. They are formed by viral proteins displaying a high density of epitopes. Besides their high thermal stability, they lack any viral DNA/RNA, which makes them non-infectious. Furthermore, they can have non-protein antigens coupled to the surface and can induce cross-protection against different viruses. FDA vaccines have already approved some VLPs for the prevention of human papillomavirus, and hepatitis (Gregory et al., 2013; Poon and Patel, 2020). Moreover, a patent application was requested by Novavax for a MERS-CoV VLPs vaccine in 2015. The same company announced that their vaccine candidates for COVID19 were developed using a recombinant NPs vaccine technology (Liu et al., 2020).

Several other nanotechnology-based systems have been used as carriers or adjuvants in the development of vaccines, among them AuNPs, which have been investigated against more than 45 pathogens, at different sizes, shapes, and functionalization (Dykman, 2020). Two important reviews summarize the conjugation of these metallic NPs with several viral antigens. We highlight a study that demonstrated the production of high levels of specific antibodies to M2e, a highly preserved peptide among serotypes, 15 months after immunization against influenza (Bimler et al., 2019). Aluminum NPs are another metallic structure that could be used in vaccines for respiratory pathogens, such as MERS-CoV and SARS-CoV, delivering antigens and inducing both humoral and cellular immune responses (Wang N. et al., 2020).

Recently, a significant result for COVID-19 was demonstrated by Sekimukai et al. AuNPs functionalized with $S$ protein of SARS-CoV induced an antigen-specific response, however, they did not induce protective antibodies as nano vaccines and limited eosinophilic infiltration. This insufficient immunization against SARS-CoV indicates that more studies are needed for the development of better adjuvants to assist not only in SARS but also in MERS and COVID-19 situations (Sekimukai et al., 2020). 
TABLE 3 | Nanomaterials used as adjuvants or delivery systems for viral diseases.

\begin{tabular}{|c|c|c|c|c|}
\hline NPs type & Immunogen & Disease & NM used as & References \\
\hline AgNPs & Inactivated influenza virus & Influenza A (H3N2) & $A D$ & $\begin{array}{l}\text { Sanchez-Guzman et al., } \\
2019\end{array}$ \\
\hline Alginate NPs & Whole inactivated influenza virus & Influenza A (H1N1) & DS & Dehghan et al., 2018 \\
\hline AuNPs & Domain III of the envelope glycoprotein & dengue & $\mathrm{DS} / \mathrm{AD}$ & Quach et al., 2018 \\
\hline AuNPs & Hemagglutinin and TLR5 agonist flagellin & Influenza A (H3N2) & $\mathrm{DS} / \mathrm{AD}$ & Wang et al., 2017 \\
\hline AuNPs & Matrix protein 2 (M2e) & Influenza A & DS & Tao et al., 2014 \\
\hline AuNPs & Matrix protein 2 (M2e) & $\begin{array}{l}\text { Influenza A (H1N1, H3N2, and } \\
\text { H5N1) }\end{array}$ & DS & Tao et al., 2017 \\
\hline AuNPs & S protein of SARS-CoV & SARS-CoV & $\mathrm{DS} / \mathrm{AD}$ & Sekimukai et al., 2020 \\
\hline AuNPs & Viral antigen & TGEV & $\mathrm{DS} / \mathrm{AD}$ & Staroverov et al., 2019 \\
\hline AuNPs & Virus peptide & Foot-and-mouth disease & DS & Chen et al., 2010 \\
\hline AuNRs & HIV-1 Env plasmid DNA & HIV-1 & $\mathrm{DS} / \mathrm{AD}$ & Xu et al., 2012 \\
\hline Calcium phosphate NPs & Plasmid DNA & Hepatitis B & DS & $\begin{array}{l}\text { Rojas-Sánchez et al., } \\
2020\end{array}$ \\
\hline Calcium phosphate NPs & Viral hemagglutinin & Influenza A (H5N1) & $\mathrm{DS} / \mathrm{AD}$ & Morcol et al., 2019 \\
\hline Chitosan NPs & Hepatitis B surface antigen & Hepatitis B & $\mathrm{DS} / \mathrm{AD}$ & Lugade et al., 2013 \\
\hline Chitosan NPs & Hepatitis B surface antigen & Hepatitis B & DS & Prego et al., 2010 \\
\hline Chitosan NPs & Newcastle virus & Newcastle disease & DS & Zhao et al., 2012 \\
\hline Chitosan NPs & Newcastle virus protein & Newcastle disease & $A D$ & Yang et al., 2020 \\
\hline Chitosan NPs & Nucleocapsid protein & SARS-CoV & DS & Raghuwanshi et al., 2012 \\
\hline Chitosan/poly- $\varepsilon$-caprolactone & Hepatitis B surface antigen & Hepatitis B & $\mathrm{DS} / \mathrm{AD}$ & Jesus et al., 2016 \\
\hline Dendrimer-RNA NPs & RNA & Ebola and H1N1 & DS & Chahal et al., 2016 \\
\hline Dendrimer-RNA NPS & RNA & Zika & DS & Chahal et al., 2017 \\
\hline Ferritin NPs & Viral hemagglutinin & $\mathrm{H} 1 \mathrm{~N} 1$ & DS & Kanekiyo et al., 2013 \\
\hline Hollow mesoporous silica NPs + VLPs & Capsid proteins VP0, VP1, and VP3 & foot-and-mouth disease & $\mathrm{DS} / \mathrm{AD}$ & Bai et al., 2019 \\
\hline Hollow polymeric NPs & STING and MERS-CoV RBD antigen & MERS-CoV & DS & Lin et al., 2019 \\
\hline Liposomes & Membrane-proximal external region peptides & HIV & DS & Hanson et al., 2015 \\
\hline Liposomes & RNA & Chikungunya & DS & Abeyratne et al., 2020 \\
\hline Maltodextrin NPs & Inactivated virus & Influenza A (H3N2) & DS & Le et al., 2020 \\
\hline Mannose-modified PLGA NPs & Hepatitis B surface protein & Hepatitis B & DS & Zhu J. et al., 2020 \\
\hline Nanocapsulated Sapomax & Whole influenza virus antigens (WVAs) & Influenza A (H3N2) & $A D$ & $\begin{array}{l}\text { Turmagambetova et al., } \\
2020\end{array}$ \\
\hline Nanostructured lipid carrier (NLC) & RNA & Zika & DS & Erasmus et al., 2018 \\
\hline $\begin{array}{l}\text { Norovirus virus-like particles + rVP6 (rotavirus } \\
\text { protein) nanostructures }\end{array}$ & $\begin{array}{l}\text { EV CVB1 VLPs, NoV Gll.4 VLPs and RV rVP6 } \\
\text { proteins }\end{array}$ & Enteric disease & DS/AD & Heinimäki et al., 2019 \\
\hline Nucleoprotein NPs + PapMV-M2e Nps & $\begin{array}{l}\text { Matrix protein } 2(\mathrm{M} 2 \mathrm{e}) \text { and the nucleoprotein } \\
(\mathrm{NP}) \text { antigens }\end{array}$ & $\mathrm{H} 1 \mathrm{~N} 1$ and $\mathrm{H} 3 \mathrm{~N} 2$ & DS/AD & Bolduc et al., 2018 \\
\hline Oil-in-water nanoemulsion & Inactivated and a live attenuated H5N2 & $\mathrm{H} 5 \mathrm{~N} 1$ & $A D$ & Cao et al., 2016 \\
\hline PEI NPS & Spike protein DNA & SARS-CoV & DS & Shim et al., 2010 \\
\hline PLGA and PLA NPS & Hepatitis B surface antigen & Hepatitis B & DS & Thomas et al., 2011 \\
\hline PLGA and polyanhydride NPs & Influenza A virus antigen & Influenza A & DS & Renu et al., 2018 \\
\hline PLGA NPs & HTLV-1 epitopes & HTLV-1 & DS & Kabiri et al., 2018 \\
\hline PLGA NPS & Peptide antigen & $\mathrm{H} 1 \mathrm{~N} 1$ & DS & Hiremath et al., 2016 \\
\hline $\begin{array}{l}\text { Polyanhydride NPs + pentablock copolymer } \\
\text { micelles }\end{array}$ & Hemagglutinin and nucleoprotein antigens & H1N1 IAV & DS/AD & Ross et al., 2019 \\
\hline Polyphosphazenes NPs & Influenza strain AWSN/OVAI & $\mathrm{H} 1 \mathrm{~N} 1$ & DS & Schulze et al., 2017 \\
\hline Porous maltodextrin NPs & Viral hemagglutinin & Influenza A (H1N1) & DS & Bernasconi et al., 2018 \\
\hline Silica NPs & $\begin{array}{l}\text { Full-length Hepatitis B virus core protein as } \\
\text { VLPs }\end{array}$ & Hepatitis B & $A D$ & Skrastina et al., 2014 \\
\hline Spike protein NPs & Full-length spike protein & MERS-CoV & DS & Jung et al., 2018 \\
\hline Spike protein NPs & Recombinant spike protein & MERS-CoV & DS & Coleman et al., 2017 \\
\hline Star NPs (PAMAN dendrimer core) & Man9V3 glycopeptide & HIV-1 & DS & Francica et al., 2019 \\
\hline VLPS & RSV fusion protein & Respiratory Syncytial disease & DS & Lee et al., 2017 \\
\hline VLPS & Structural and envelope proteins & HIV-1 & DS & Barnowski et al., 2019 \\
\hline Virus-mimetic polymer NPs & Viral hemagglutinin & Influenza & DS & Lee C. et al., 2018 \\
\hline VLPs + Au star NPs & VP0, VP1, and VP3 proteins & Foot-and-mouth disease & DS/AD & Teng et al., 2018 \\
\hline VLPs produced with AuNPs & Avian coronavirus spike protein & Avian infectious bronchitis & DS & Chen et al., 2016 \\
\hline
\end{tabular}

$N M$, nanomaterial; $A D$, adjuvant; $D S$, delivery system. 


\section{Nanomaterials for COVID-19 prevention}

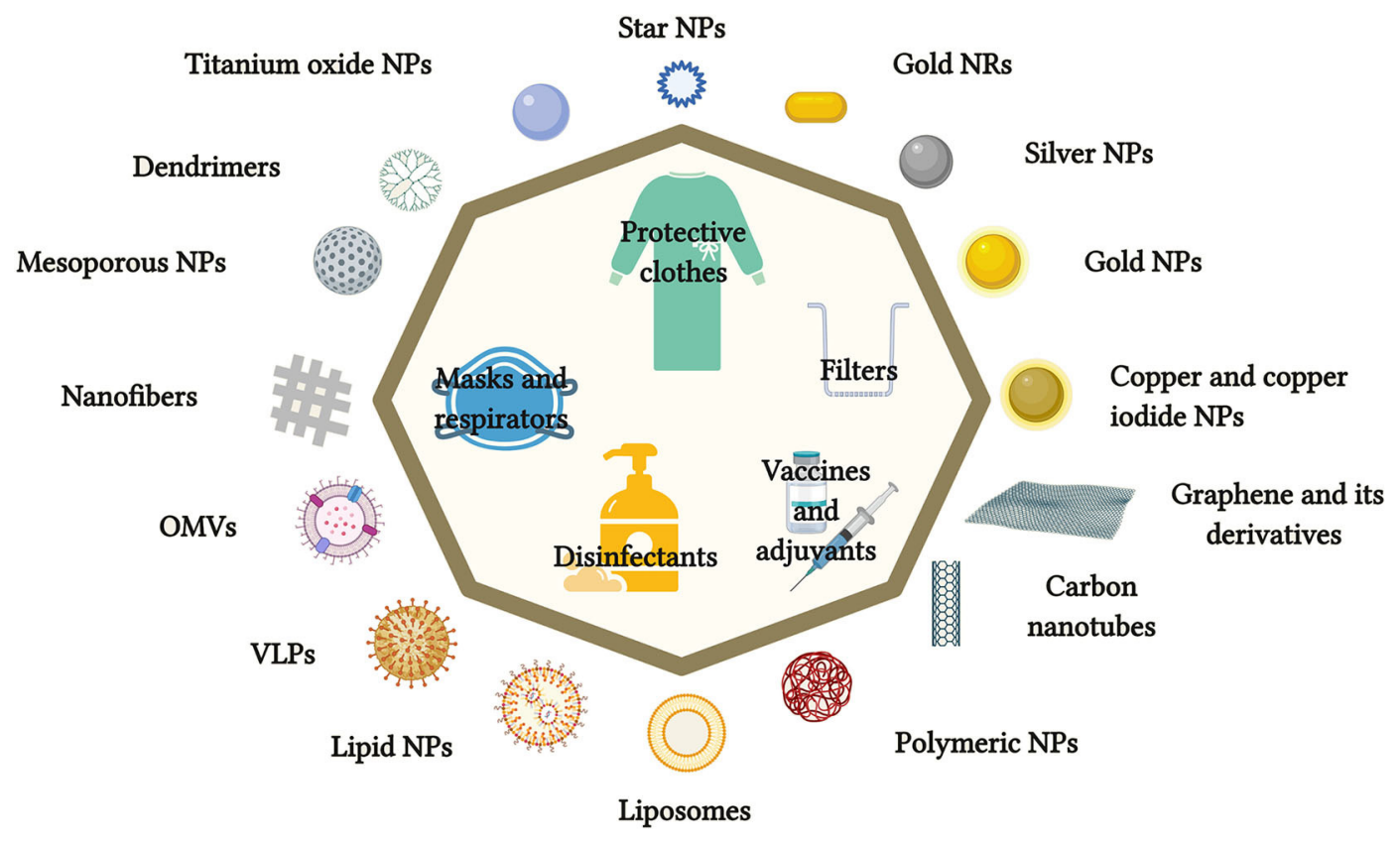

FIGURE 5 | Schematic representation of the nanomaterials used in COVID-19 prevention (figure created with BioRender.com).

MSNPs present high surface area and large pore volume, which enable vaccine antigen incorporation by co-condensation or post-synthesis grafting (Poon and Patel, 2020). Guo et al. have demonstrated that MSNPs provide a slow release of proteins, resulting in an extended last immune response in mice (Guo et al., 2012).

Although they are widely applied to cancer treatment, cell-membrane-based nanostructures are also promising for antibacterial or antiviral vaccines (Rao et al., 2020). They can include membrane-coated NPs and vesicular structures, such as outer membrane vesicles (OMVs) and exosomes (Fang et al., 2017). Bacteria release OMVs as spherical structures (50$200 \mathrm{~nm}$ ), which can be highly immunogenic. A dual vaccine for Influenza A H1N1 and MERS-CoV viruses based on OMVs had been recently proposed by Shehata et al. (2019). Currently, OMVs are being applied for COVID-19 vaccines (World Health Organization, 2020a) and there are four ongoing preclinical trials for protein subunit delivery from Intravacc/Epivax (in two trials), Quadram Institute Biosciences, and BiOMViS Srl/University of Trento (World Health Organization, 2020a).

In addition to antigen and genetic material delivery, NPs can be used as a substitute for aluminum-containing adjuvants. The mechanism is not clear, but it is suggested that these nanomaterials increase antigen uptake and promote the immunostimulation of antigen-presenting cells (Zaman et al., 2013). Graphene, nanodiamonds, and polystyrene particles can induce immune system activation, as well as CNTs, depending on their functionalization (Weiss et al., 2020). IONPs (Poon and Patel, 2020), AgNPs (Sanchez-Guzman et al., 2019), cobalt oxide NPs (Cho et al., 2012), aluminum NPs (Wang N. et al., 2020), AuNPs (Teng et al., 2018; Dykman, 2020), Au nanorods (Xu et al., 2012), and MSNPs (Carvalho et al., 2010) have also been evaluated as adjuvants in the immunization process. For instance, aluminum NPs were used as vaccine adjuvantdelivery systems (VADS) for pulmonary immunization using ovalbumin as a model antigen, improving the drainage of VADS to lymph nodes. This strategy represents a promising tool for targeting the vaccines to the respiratory tract, against pathogen microorganisms such as SARS-CoV and MERS-CoV (Wang N. et al., 2020).

Some studies using nanotechnology-based delivery and adjuvant for viral diseases are listed in Table 3. Nasrollahzadeh et al. and Nikaeen et al. have reported examples of NPs as virus vaccine delivery systems. Among them are AuNPs, chitosan NPs, VLPs, alginate-coated chitosan NPs, PLA and PLGA NPs, and di-lauroyl phosphatidylcholine liposomes. They highlight gold, ferritin, and S protein polymeric NPs as $\mathrm{CoV}$ vaccine candidates (Nasrollahzadeh et al., 2020; Nikaeen et al., 2020).

In the current situation, one of the main concerns is the development of a specific vaccine that provides safe and efficient prophylactic measures against SARS-CoV-2. All the studies described here have demonstrated the potential of nanotechnology to design effective immunization strategies. In pre-clinical COVID-19 studies among 139 candidates, several are based on nanomaterials such as a VLP developed by Geovax/BravoVax, an S protein subunit liposomal formulation 
for nasal delivery proposed by the University of Virginia, a lipidbased NPs for peptide delivery from IMV Inc., and recombinant protein NPs studied by the Saint-Petersburg research Institute (World Health Organization, 2020a).

One of the first clinical studies to evaluate the safety and immunogenicity of an NPs vaccine based on SARS-CoV-2 recombinant $S$ protein with the MATRIX-M ${ }^{\mathrm{TM}}$ Adjuvant I is being conducted by Novavax (NCT04368988). Other studies have used lipid-based NPs for RNA delivery (NCT04283461, ISRCTN 17072692, and NCT04368728) and plant-derived VLP (NCT04450004). Great expectations have been generated around vaccines, since the Moderna company, responsible for one of the RNA vaccines, announced that the product is potentially protective, eliciting antibody levels above the titers obtained for convalescent people in some initial participants (Weiss et al., 2020). Several other clinical trials are also underway to obtain a vaccine to SARS-CoV-2 (U.S. National Library of Medicine, 2020; World Health Organization, 2020a), and in Figure 5 we summarize the nanomaterials that can be used in the prevention against SARS-CoV-2.

\section{CONCLUSIONS}

Since December 2019, the SARS-CoV-2 outbreak has taken many lives and put countries all over the world on high alert. The severe nature of this COVID-19 pandemic situation highlights the importance of new technological proposals as a means of containing and stopping the spread of disease. The lack of approved antiviral drugs or vaccines, as well as the low efficacy and occurrence of adverse reactions, requires the use of novel therapeutic strategies against COVID-19. Currently, standard therapeutic approaches are based on antiviral drugs and adjuvant molecules that are already used in other viral diseases, and which can inhibit the virus uptake in tissues and block proteases activity in the infected cells. However, this strategy only decreases virus replication and symptoms.

Nanomedicine is a significant resource in the fight against novel coronavirus, but its use in clinical practice still presents great challenges, mainly concerning in vivo behavior, nanocarriers toxicity, and production on an industrial scale. Other important issues are a lack of a higher understanding of the particular characteristics and aspects of disease physiopathology, the processes involved in the nano-biointerface, as well as biocompatibility, safety, and regulatory issues. COVID-19

\section{REFERENCES}

Aanouz, I., Belhassan, A., El-Khatabi, K., Lakhlifi, T., El-ldrissi, M., and Bouachrine, M. (2020). Moroccan medicinal plants as inhibitors against SARSCoV-2 main protease: computational investigations. J. Biomol. Struct. Dyn. 6, 1-9. doi: 10.1080/07391102.2020.1758790

Abbasi-Oshaghi, E., Mirzaei, F., Farahani, F., Khodadadi, I., and Tayebinia, H. (2020). Diagnosis and treatment of coronavirus disease 2019 (COVID-19): laboratory, PCR, and chest CT imaging findings. Int. J. Surg. 79, 143-153. doi: 10.1016/j.ijsu.2020.05.018

Abeyratne, E., Tharmarajah, K., Freitas, J. R., Mostafavi, H., Mahalingam, S., Zaid, A., et al. (2020). Liposomal delivery of the RNA genome specific features and the physicochemical properties of the nanosystems can be explored and used to design personalized nanostructures for specific therapeutic purposes, seeking to neutralize the current threat to global public health and create more sustainable approaches based on nanotechnology. Although these factors have not yet been fully explored, they are essential for the safe and effective implementation of nanotechnologies against SARS-CoV-2 infection.

This review has discussed how nanotechnology could be used to prevent viral dissemination, improving the efficiency of protective equipment, increasing personal and social safety, and increasing the accuracy of COVID-19 diagnosis through fast and precise detection of infectious pathogens that involve a tiny volume of biological fluids. Moreover, nanosystems improve conventional therapies and aid in overcoming their therapeutic barrier since these nanocarriers can be modified to deliver antiviral molecules direct to diseased cells and, simultaneously, activate a host immune response against the virus. Therefore, nanomedicine has significant benefits for the prevention, diagnosis, and treatment of COVID-19, but it needs to be further explored and understood. The absence of antiviral therapies against COVID-19 in many ways presents an opportunity to boost the use of nanotechnological tools in virology.

\section{AUTHOR CONTRIBUTIONS}

VC: supervision, conceptualization, investigation, writing, review, and editing. BM, EC, IS, LF, and PL: conceptualization, investigation, writing, and review. VZ: supervision, conceptualization, project administration, and funding acquisition. All authors contributed to the article and approved the submitted version.

\section{ACKNOWLEDGMENTS}

The authors are thankful for the financial support of the Fundação de Amparo à Pesquisa do Estado de São Paulo (FAPESP) (Grant No. 2014/50947-7), Conselho Nacional de Desenvolvimento Científico e Tecnológico (CNPq) (Grant No. 440496/2016-0), and Coordenação de Aperfeiçoamento de Pessoal de Nível Superior, Brasil (CAPES) (Grants No. 88881.130763/2016-01 and 23038.013951/2020-79). of a live-attenuated chikungunya virus vaccine candidate provides local, but not systemic protection after one dose. Front. Immunol. 11:304. doi: 10.3389/fimmu.2020.00304

Adhikari, S. P., Meng, S., Wu, Y.-J., Mao, Y.-P., Ye, R.-X., Wang, Q.-Z., et al. (2020). Epidemiology, causes, clinical manifestation and diagnosis, prevention and control of coronavirus disease (COVID-19) during the early outbreak period: a scoping review. Infect. Dis. Poverty 9, 1-12. doi: 10.1186/s40249-020-0 0646-x

Ahmed, M. M., Fatima, F., Anwer, K., Alshahrani, S. M., Alalaiwe, A., and Katakam, P. (2019). Biosynthesis, characterization and anti-microbial activity of silver nanoparticle based gel hand wash. Green Process. Synth. 8, 577-583. doi: 10.1515/gps-2019-0027 
Ahmed, S. F., Quadeer, A. A., and McKay, M. R. (2020). Preliminary identification of potential vaccine targets for the COVID-19 Coronavirus (SARS-CoV-2) Based on SARS-CoV immunological studies. Viruses 12:254. doi: $10.3390 / \mathrm{v} 12030254$

Ajdary, M., Moosavi, M. A., Rahmati, M., Falahati, M., Mahboubi, M., Mandegary, A., et al. (2018). Health concerns of various nanoparticles: a review of their in vitro and in vivo toxicity. Nanomaterials 8:634. doi: 10.3390/nano8090634

Akbarzadeh, A., Rezaei-Sadabady, R., Davaran, S., Joo, S. W., Zarghami, N., Hanifehpour, Y., et al. (2013). Liposome: classification, preparation, and applications. Nanoscale Res. Lett. 8:102. doi: 10.1186/1556-276X-8-102

Akduman, C., and Akcakoca Kumbasar, E. P. (2018). Nanofibers in face masks and respirators to provide better protection. IOP Conf. Ser. Mater. Sci. Eng. 460:012013. doi: 10.1088/1757-899X/460/1/012013

Alidori, S., Bowman, R. L., Yarilin, D., Romin, Y., Barlas, A., Mulvey, J. J., et al. (2016). Deconvoluting hepatic processing of carbon nanotubes. Nat. Commun. 7:12343. doi: $10.1038 /$ ncomms 12343

Anastasopoulou, S., and Athanasia, M. (2020). The biology of SARS-CoV-2 and the ensuing COVID-19. Achaiki Iatriki 39, 29-35.

Anselmo, A. C., and Mitragotri, S. (2015). A review of clinical translation of inorganic nanoparticles. AAPS J. 17, 1041-1054. doi: $10.1208 /$ s12248-015-9780-2

Anselmo, A. C., and Mitragotri, S. (2019). Nanoparticles in the clinic: an update. Bioeng. Transl. Med. 4:e10143. doi: 10.1002/btm2.10143

Arabi, Y. M., Arifi, A. A., Balkhy, H. H., Najm, H., Aldawood, A. S., Ghabashi, A., et al. (2014). Clinical course and outcomes of critically ill patients with Middle East respiratory syndrome coronavirus infection. Ann. Intern. Med. 160, 389-397. doi: 10.7326/M13-2486

Aragao-Santiago, L., Hillaireau, H., Grabowski, N., Mura, S., Nascimento, T. L., Dufort, S., et al. (2016). Compared in vivo toxicity in mice of lung delivered biodegradable and non-biodegradable nanoparticles. Nanotoxicology 10, 292-302. doi: 10.3109/17435390.2015.1054908

Astuti, I., and Ysrafil (2020). Severe acute respiratory syndrome coronavirus 2 (SARS-CoV-2): an overview of viral structure and host response. Diabetes Metab. Syndr. Clin. Res. Rev. 14, 407-412. doi: 10.1016/j.dsx.2020.04.020

Azmi, I. D. M., Moghimi, S. M., and Yaghmur, A. (2015). Cubosomes and hexosomes as versatile platforms for drug delivery. Ther. Deliv. 6, 1347-1364. doi: $10.4155 /$ tde. 15.81

Bai, M., Dong, H., Su, X., Jin, Y., Sun, S., Zhang, Y., et al. (2019). Hollow mesoporous silica nanoparticles as delivery vehicle of foot-and-mouth disease virus-like particles induce persistent immune responses in guinea pigs. J. Med. Virol. 91, 941-948. doi: 10.1002/jmv.25417

Balagna, C., Perero, S., Percivalle, E., Nepita, E. V., and Ferraris, M. (2020). Virucidal effect against Coronavirus SARS-CoV-2 of a silver nanocluster/silica composite sputtered coating. Open Ceram. 1:100006. doi: 10.1016/j.oceram.2020.100006

Banerjee, R., and Jaiswal, A. (2018). Recent advances in nanoparticle-based lateral flow immunoassay as a point of care diagnostic tool for infectious agents and diseases. Analyst 143, 1970-1996. doi: 10.1039/C8AN00307F

Baram-Pinto, D., Shukla, S., Gedanken, A., and Sarid, R. (2010). Inhibition of HSV1 attachment, entry, and cell-to-cell spread by functionalized multivalent gold nanoparticles. Small 6, 1044-1050. doi: 10.1002/smll.200902384

Barnowski, C., Kadzioch, N., Damm, D., Yan, H., and Temchura, V. (2019). Advantages and limitations of integrated flagellin adjuvants for HIV-based nanoparticle B-cell vaccines. Pharmaceutics 11:204. doi: 10.3390/pharmaceutics 11050204

Bar-On, Y. M., Flamholz, A., Phillips, R., and Milo, R. (2020). SARS-CoV-2 (COVID-19) by the numbers. Elife 9:e57309. doi: 10.7554/eLife.57309.sa2

Barriga, H. M. G., Holme, M. N., and Stevens, M. M. (2019). Cubosomes: the next generation of smart lipid nanoparticles? Angew. Chem. Int. Ed. 58, 2958-2978. doi: $10.1002 /$ anie.201804067

Bawa, R., Audette, G. F., and Rubinstein, I. (2016). Handbook of Clinical Nanomedicine: Nanoparticles, Imaging, Therapy, and Clinical Applications. Boca Raton, FL: CRC Press. doi: 10.1201/b19915

Bernasconi, V., Bernocchi, B., Ye, L., Lê, M. Q., Omokanye, A., Carpentier, R., et al. (2018). Porous nanoparticles with self-adjuvanting M2e-fusion protein and recombinant hemagglutinin provide strong and broadly protective immunity against influenza Virus infections. Front. Immunol. 9:2060. doi: $10.3389 /$ fimmu.2018.02060
Bernstein, D. I., Cardin, R. D., Bravo, F. J., Hamouda, T., Pullum, D. A., Cohen, G., et al. (2019). Intranasal nanoemulsion-adjuvanted HSV-2 subunit vaccine is effective as a prophylactic and therapeutic vaccine using the guinea pig model of genital herpes. Vaccine 37, 6470-6477. doi: 10.1016/j.vaccine.2019.08.077

Beyerle, A., Braun, A., Banerjee, A., Ercal, N., Eickelberg, O., Kissel, T. H., et al. (2011). Inflammatory responses to pulmonary application of PEI-based siRNA nanocarriers in mice. Biomaterials 32, 8694-8701. doi: 10.1016/j.biomaterials.2011.07.082

Bimler, L., Song, A. Y., Le, D. T., Murphy Schafer, A., and Paust, S. (2019). AuNP-M2 ${ }^{\mathrm{e}+} \mathrm{sCpG}$ vaccination of juvenile mice generates lifelong protective immunity to influenza A virus infection. Immun. Ageing 16:23. doi: 10.1186/s12979-019-0162-y

Bisso, S., and Leroux, J. C. (2020). Nanopharmaceuticals: a focus on their clinical translatability. Int. J. Pharm. 578:119098. doi: 10.1016/j.ijpharm.2020.119098

Blaising, J., Polyak, S. J., and Pécheur, E.-I. (2014). Arbidol as a broad-spectrum antiviral: an update. Antiviral Res. 107, 84-94. doi: 10.1016/j.antiviral.2014.04.006

Bolduc, M., Baz, M., Laliberté-Gagné, M. Ė., Carignan, D., Garneau, C., Russel, A., et al. (2018). The quest for a nanoparticle-based vaccine inducing broad protection to influenza viruses. Nanomed. Nanotechnol. Biol. Med. 14, 2563-2574. doi: 10.1016/j.nano.2018.08.010

Boopathi, S., Poma, A. B., and Kolandaivel, P. (2020). Novel 2019 coronavirus structure, mechanism of action, antiviral drug promises and rule out against its treatment. J. Biomol. Struct. Dyn. 30:1-10. doi: 10.1080/07391102.2020.1758788

Boyce, J. M. (2016). Modern technologies for improving cleaning and disinfection of environmental surfaces in hospitals. Antimicrob. Resist. Infect. Control 5, 1-10. doi: 10.1186/s13756-016-0111-x

Brady-Estévez, A. S., Schnoor, M. H., Vecitis, C. D., Saleh, N. B., and Elimelech, M. (2010). Multiwalled carbon nanotube filter: improving viral removal at low pressure. Langmuir 26, 14975-14982. doi: 10.1021/la102783v

Brazaca, L. C., Moreto, J. R., Martín, A., Tehrani, F., Wang, J., and Zucolotto, V. (2019). Colorimetric paper-based immunosensor for simultaneous determination of fetuin $\mathrm{b}$ and clusterin toward early alzheimer's diagnosis. ACS Nano 13, 13325-13332. doi: 10.1021/acsnano.9b06571

Bromberg, L., Bromberg, D. J., Hatton, T. A., Bandín, I., Concheiro, A., and Alvarez-Lorenzo, C. (2012). Antiviral properties of polymeric aziridineand biguanide-modified core-shell magnetic nanoparticles. Langmuir 28, 4548-4558. doi: 10.1021/la205127x

Cagno, V., Andreozzi, P., D’Alicarnasso, M., Silva, P. J., Mueller, M., Galloux, M., et al. (2018). Broad-spectrum non-toxic antiviral nanoparticles with a virucidal inhibition mechanism. Nat. Mater. 17, 195-203. doi: 10.1038/nmat5053

Cai, Q., Yang, M., Liu, D., Chen, J., Shu, D., Xia, J., et al. (2020). experimental treatment with favipiravir for COVID-19: an open-label control study. Engineering. [Preprint]. doi: 10.1016/j.eng.2020.03.007

Cao, B., Wang, Y., Wen, D., Liu, W., Wang, J., Fan, G., et al. (2020). A trial of lopinavir-ritonavir in adults hospitalized with severe Covid-19. N. Engl. J. Med. 382, 1787-1799. doi: 10.1056/NEJMoa2001282

Cao, W., Davis, W. G., Kim, J. H., De La Cruz, J. A., Taylor, A., Hendrickson, G. R., et al. (2016). An oil-in-water nanoemulsion enhances immunogenicity of H5N1 vaccine in mice. Nanomed. Nanotechnol. Biol. Med. 12, 1909-1917. doi: 10.1016/j.nano.2016.04.005

Cao, W., Liu, X., Bai, T., Fan, H., Hong, K., Song, H., et al. (2020). Highdose intravenous immunoglobulin as a therapeutic option for deteriorating patients with coronavirus disease 2019. Open Forum Inf. Dis. 7:ofaa102. doi: 10.1093/ofid/ofaa102

Cao, Y., Deng, Q., and Dai, S. (2020). Remdesivir for severe acute respiratory syndrome coronavirus 2 causing COVID-19: an evaluation of the evidence. Travel Med. Infect. Dis. 35:101647. doi: 10.1016/j.tmaid.2020. 101647

Carvalho, L. V., Ruiz, R. D. C., Scaramuzzi, K., Marengo, E. B., Matos, J. R., Tambourgi, D. V., et al. (2010). Immunological parameters related to the adjuvant effect of the ordered mesoporous silica SBA-15. Vaccine 28, 7829-7836. doi: 10.1016/j.vaccine.2010. 09.087

Cavalli, R., Donalisio, M., Civra, A., Ferruti, P., Ranucci, E., Trotta, F., et al. (2009). Enhanced antiviral activity of acyclovir loaded into $\beta$-cyclodextrinpoly(4-acryloylmorpholine) conjugate nanoparticles. J. Control. Release 137, 116-122. doi: 10.1016/j.jconrel.2009.04.004 
Cavezzi, A., Troiani, E., and Corrao, S. (2020). COVID-19: hemoglobin, iron, and hypoxia beyond inflammation. A narrative review. Clin. Pract. 10:1271. doi: $10.4081 /$ cp. 2020.1271

Chahal, J. S., Fang, T., Woodham, A. W., Khan, O. F., Ling, J., Anderson, D. G., et al. (2017). An RNA nanoparticle vaccine against zika virus elicits antibody and CD8+ T cell responses in a mouse model. Sci. Rep. 7:252. doi: 10.1038/s41598-017-00193-w

Chahal, J. S., Khan, O. F., Cooper, C. L., McPartlan, J. S., Tsosie, J. K., Tilley, L. D., et al. (2016). Dendrimer-RNA nanoparticles generate protective immunity against lethal ebola, H1N1 influenza, and Toxoplasma gondii challenges with a single dose. Proc. Natl. Acad. Sci. U.S.A. 113, E4133-E4142. doi: $10.1073 /$ pnas. 1600299113

Chan, J. F.-W., Yao, Y., Yeung, M.-L., Deng, W., Bao, L., Jia, L., et al. (2015). Treatment with lopinavir/ritonavir or interferon- $\beta 1 \mathrm{~b}$ improves outcome of MERS-CoV infection in a nonhuman primate model of common marmoset. J. Infect. Dis. 212, 1904-1913. doi: 10.1093/infdis/jiv392

Chapman, J., Regan, F., Sullivan, T., and Chemistry, R. S., of (2012). Nanoparticles in Anti-microbial Materials: Use and Characterisation. Royal Society of Chemistry. Available online at: https://books.google.com.br/books? id=IDfhf23Wb_IC (accessed June 20, 2020).

Chauhan, G., Madou, M. J., Kalra, S., Chopra, V., Ghosh, D., and MartinezChapa, S. O. (2020). Nanotechnology for COVID-19: therapeutics and vaccine research. ACS Nano 14, 7760-7782. doi: 10.1021/acsnano.0c04006

Chen, H., Zhang, Z., Wang, L., Huang, Z., Gong, F., Li, X., et al. (2020). First clinical study using HCV protease inhibitor danoprevir to treat naive and experienced COVID-19 patients. medRxiv [Preprint]. doi: 10.1101/2020.03.22.20034041

Chen, H. W., Huang, C. Y., Lin, S. Y., Fang, Z. S., Hsu, C. H., Lin, J. C., et al. (2016). Synthetic virus-like particles prepared via protein corona formation enable effective vaccination in an avian model of coronavirus infection. Biomaterials 106, 111-118. doi: 10.1016/j.biomaterials.2016.08.018

Chen, Y.-C., Cheng, H.-F., Yang, Y.-C., and Yeh, M.-K. (2017). Nanotechnologies applied in biomedical vaccines. J. Pharm. Pharmacol. 5, 57-72. doi: 10.5772/intechopen.69547

Chen, Y. S., Hung, Y. C., Lin, W. H., and Huang, G. S. (2010). Assessment of gold nanoparticles as a size-dependent vaccine carrier for enhancing the antibody response against synthetic foot-and-mouth disease virus peptide. Nanotechnology 21:195101. doi: 10.1088/0957-4484/21/19/195101

Chhikara, B., Rathi, B., Singh, J., and Poonam (2020). Corona virus SARSCoV-2 disease COVID-19: infection, prevention and clinical advances of the prospective chemical drug therapeutics. Chem. Biol. Lett. 7, 63-72. Available online at: https://covid-19.conacyt.mx/jspui/bitstream/1000/605/1/100431.pdf

Cho, W. S., Dart, K., Nowakowska, D. J., Zheng, X., Donaldson, K., and Howie, S. E. M. (2012). Adjuvanticity and toxicity of cobalt oxide nanoparticles as an alternative vaccine adjuvant. Nanomedicine 7, 1495-1505. doi: $10.2217 / \mathrm{nnm} .12 .35$

Chuan, J., Li, Y., Yang, L., Sun, X., Zhang, Q., Gong, T., et al. (2013). Enhanced rifampicin delivery to alveolar macrophages by solid lipid nanoparticles. J. Nanoparticle Res. 15:1634. doi: 10.1007/s11051-013-1634-1

Chughtai, A. A., Seale, H., and MacIntyre, C. R. (2013). Availability, consistency and evidence-base of policies and guidelines on the use of mask and respirator to protect hospital health care workers: a global analysis. BMC Res. Notes 6:216. doi: 10.1186/1756-0500-6-216

Clayton, R., Ohagen, A., Nicol, F., Del Vecchio, A. M., Jonckers, T. H. M., Goethals, O., et al. (2009). Sustained and specific in vitro inhibition of HIV-1 replication by a protease inhibitor encapsulated in gp120-targeted liposomes. Antiviral Res. 84, 142-149. doi: 10.1016/j.antiviral.2009.08.003

Coleman, C. M., Liu, Y. V., Mu, H., Taylor, J. K., Massare, M., Flyer, D. C., et al. (2014). Purified coronavirus spike protein nanoparticles induce coronavirus neutralizing antibodies in mice. Vaccine 32, 3169-3174. doi: 10.1016/j.vaccine.2014.04.016

Coleman, C. M., Venkataraman, T., Liu, Y. V., Glenn, G. M., Smith, G. E., Flyer, D. C., et al. (2017). MERS-CoV spike nanoparticles protect mice from MERS-CoV infection. Vaccine 35, 1586-1589. doi: 10.1016/j.vaccine.2017.02.012

Comparetti, E. J., Pedrosa, V., de, A., and Kaneno, R. (2018). Carbon nanotube as a tool for fighting cancer. Bioconjug. Chem. 29, 709-718. doi: 10.1021/acs.bioconjchem.7b00563

Conteduca, V., Sansonno, D., Russi, S., Pavone, F., and Dammacco, F. (2014). Therapy of chronic hepatitis $\mathrm{C}$ virus infection in the era of direct-acting and host-targeting antiviral agents. J. Infect. 68, 1-20. doi: 10.1016/j.jinf.2013.08.019
Croci, R., Bottaro, E., Chan, K. W. K., Watanabe, S., Pezzullo, M., Mastrangelo, E., et al. (2016). Liposomal systems as nanocarriers for the antiviral agent ivermectin. Int. J. Biomater. 2016. doi: 10.1155/2016/804 3983

Dalakas, M. C. (2020). Guillain-Barré syndrome: the first documented COVID-19-triggered autoimmune neurologic disease: more to come with myositis in the offing. Neurol. Neuroimmunol. Neuroinflam. 7:e781. doi: 10.1212/NXI.0000000000000781

Dau, T. N. N., Vu, V. H., Cao, T. T., Nguyen, V. C., Ly, C. T., Tran, D. L., et al. (2019). In-situ electrochemically deposited $\mathrm{Fe}_{3} \mathrm{O}_{4}$ nanoparticles onto graphene nanosheets as amperometric amplifier for electrochemical biosensing applications. Sensors Actuators B Chem. 283, 52-60. doi: 10.1016/j.snb.2018.11.152

De Matteis, V. (2017). Exposure to inorganic nanoparticles: routes of entry, immune response, biodistribution and in vitro/in vivo toxicity evaluation. Toxics 5:29. doi: 10.3390/toxics5040029

Dehghan, S., Kheiri, M. T., Abnous, K., Eskandari, M., and Tafaghodi, M. (2018). Preparation, characterization and immunological evaluation of alginate nanoparticles loaded with whole inactivated influenza virus: dry powder formulation for nasal immunization in rabbits. Microb. Pathog. 115, 74-85. doi: 10.1016/j.micpath.2017.12.011

Deshmukh, S. P., Patil, S. M., Mullani, S. B., and Delekar, S. D. (2019). Silver nanoparticles as an effective disinfectant: a review. Mater. Sci. Eng. C 97, 954-965. doi: 10.1016/j.msec.2018.12.102

Dong, L., Hu, S., and Gao, J. (2020). Discovering drugs to treat coronavirus disease 2019 (COVID-19). Drug Discov. Ther. 14, 58-60. doi: 10.5582/ddt.2020. 01012

Drugbank (2020). Danoprevir. Available online at: https://www.drugbank.ca/ drugs/DB11779 (accessed June 15, 2020).

Du, W., Han, S., Li, Q., and Zhang, Z. (2020). Epidemic update of COVID-19 in Hubei Province compared with other regions in China. Int. J. Infect. Dis. 95, 321-325. doi: 10.1016/j.ijid.2020.04.031

Duan, K., Liu, B., Li, C., Zhang, H., Yu, T., Qu, J., et al. (2020). Effectiveness of convalescent plasma therapy in severe COVID-19 patients. Proc. Natl. Acad. Sci.U.S.A. 117, 9490-9496. doi: 10.1073/pnas.2004168117

Dykman, L. A. (2020). Gold nanoparticles for preparation of antibodies and vaccines against infectious diseases. Expert Rev. Vaccines 19, 465-477. doi: 10.1080/14760584.2020.1758070

Eastman, R. T., Roth, J. S., Brimacombe, K. R., Simeonov, A., Shen, M., Patnaik, S., et al. (2020). Remdesivir: a review of its discovery and development leading to human clinical trials for treatment of COVID-19. ACS Cent Sci. 6, 672-683. doi: 10.1021/acscentsci.0c00489

El-Atab, N., Qaiser, N., Badghaish, H., Shaikh, S. F., and Hussain, M. M. (2020). Flexible nanoporous template for the design and development of reusable anti-COVID-19 hydrophobic face masks. ACS Nano 14, 7659-7665. doi: 10.1021/acsnano.0c03976

Elbaz, N. M., Ziko, L., Siam, R., and Mamdouh, W. (2016). Core-shell silver/polymeric nanoparticles-based combinatorial therapy against breast cancer in-vitro. Sci. Rep. 6:30729. doi: 10.1038/srep30729

Eloy, J. O., Petrilli, R., Trevizan, L. N. F., and Chorilli, M. (2017) Immunoliposomes: a review on functionalization strategies and targets for drug delivery. Colloids Surfaces B Biointerfaces 159, 454-467. doi: 10.1016/j.colsurfb.2017.07.085

Erasmus, J. H., Khandhar, A. P., Guderian, J., Granger, B., Archer, J., Archer, M., et al. (2018). A nanostructured lipid carrier for delivery of a replicating viral rna provides single, low-dose protection against zika. Mol. Ther. 26, 2507-2522. doi: 10.1016/j.ymthe.2018.07.010

Faccini, M., Vaquero, C., and Amantia, D. (2012). Development of protective clothing against nanoparticle based on electrospun nanofibers. J. Nanomater. 2012:892894. doi: 10.1155/2012/892894

Fang, R. H., Jiang, Y., Fang, J. C., and Zhang, L. (2017). Cell membranederived nanomaterials for biomedical applications. Biomaterials 128, 69-83. doi: 10.1016/j.biomaterials.2017.02.041

Fehr, A. R., and Perlman, S. (2015). Coronaviruses: an overview of their replication and pathogenesis. Methods Mol. Biol. 1282, 1-23. doi: 10.1007/978-1-4939-2438-7_1

Figueroa, S. M., Veser, A., Abstiens, K., Fleischmann, D., Beck, S., and Goepferich, A. (2019). Influenza A virus mimetic nanoparticles trigger selective cell uptake. Proc. Natl. Acad. Sci. U. S. A. 116, 9831-9836. doi: 10.1073/pnas.1902563116 
Francica, J. R., Laga, R., Lynn, G. M., MuŽ́íková, G., Androvič, L., Aussedat, B., et al. (2019). Star nanoparticles delivering HIV-1 peptide minimal immunogens elicit near-native envelope antibody responses in nonhuman primates. PLoS Biol. 17:e3000328. doi: 10.1371/journal.pbio.3000328

Francis, L., Giunco, F., Balakrishnan, A., and Marsano, E. (2010). Synthesis, characterization and mechanical properties of nylon-silver composite nanofibers prepared by electrospinning. Curr. Appl. Phys. 10, 1005-1008. doi: 10.1016/j.cap.2009.12.025

Fujimori, Y., Sato, T., Hayata, T., Nagao, T., Nakayam, M., Nakayam, T., et al. (2012). Novel antiviral characteristics of nanosized copper(I) iodide particles showing inactivation activity against 2009 pandemic H1N1 influenza virus. Appl. Environ. Microbiol. 78, 951-955. doi: 10.1128/AEM.06284-11

Galdiero, S., Falanga, A., Vitiello, M., Cantisani, M., Marra, V., and Galdiero, M. (2011). Silver nanoparticles as potential antiviral agents. Molecules 16, 8894-8918. doi: 10.3390/molecules16108894

Ganesan, P., and Narayanasamy, D. (2017). Lipid nanoparticles: different preparation techniques, characterization, hurdles, and strategies for the production of solid lipid nanoparticles and nanostructured lipid carriers for oral drug delivery. Sustain. Chem. Pharm. 6, 37-56. doi: 10.1016/j.scp.2017.07.002

Gao, J., Tian, Z., and Yang, X. (2020). Breakthrough: chloroquine phosphate has shown apparent efficacy in treatment of COVID-19 associated pneumonia in clinical studies. Biosci. Trends. 14, 72-73. doi: 10.5582/bst.2020.01047

Ge, Q., Filip, L., Bai, A., Nguyen, T., Eisen, H. N., and Chen, J. (2004). Inhibition of influenza virus production in virus-infected mice by RNA interference. Proc. Natl. Acad. Sci.U.S.A. 101, 8676-8681. doi: 10.1073/pnas.0402486101

Glynn, M. T., Kinahan, D. J., and Ducrée, J. (2014). Rapid, low-cost and instrument-free CD4+ cell counting for HIV diagnostics in resource-poor settings. Lab. Chip. 14, 2844-2851. doi: 10.1039/C4LC00264D

González-Gay, M. A., Castañeda, S., and Ancochea, J. (2020). Biologic therapy in COVID-19. Arch. Bronconeumol. doi: 10.1016/j.arbres.2020.06.007

Graham, R. L., Donaldson, E. F., and Baric, R. S. (2013). A decade after SARS: strategies for controlling emerging coronaviruses. Nat. Rev. Microbiol. 11, 836-848. doi: 10.1038/nrmicro3143

Gregory, A. E., Titball, R., and Williamson, D. (2013). Vaccine delivery using nanoparticles. Front. Cell. Infect. Microbiol. 3:13. doi: $10.3389 /$ fcimb.2013.00013

Grein, J., Ohmagari, N., Shin, D., Diaz, G., Asperges, E., Castagna, A., et al. (2020). Compassionate use of remdesivir for patients with severe covid-19. N. Engl. J. Med. 382:2327-2336. doi: 10.1056/NEJMoa2007016

Guo, H. C., Feng, X. M., Sun, S. Q., Wei, Y. Q., Sun, D. H., Liu, X. T., et al. (2012). Immunization of mice by hollow mesoporous silica nanoparticles as carriers of porcine circovirus type 2 ORF2 protein. Virol. J. 9:108. doi: 10.1186/1743-422X-9-108

Gursoy, R. N., and Benita, S. (2004). Self-emulsifying drug delivery systems (SEDDS) for improved oral delivery of lipophilic drugs. Biomed. Pharmacother. 58, 173-182. doi: 10.1016/j.biopha.2004.02.001

Hageman, J. R. (2020). The coronavirus disease 2019 (COVID-19). Pediatr. Ann. 49, e99-e100. doi: 10.3928/19382359-20200219-01

Hammond, J. L., Formisano, N., Estrela, P., Carrara, S., and Tkac, J. (2016). Electrochemical biosensors and nanobiosensors. Essays Biochem. 60, 69-80. doi: 10.1042/EBC20150008

Hanson, M. C., Abraham, W., Crespo, M. P., Chen, S. H., Liu, H., Szeto, G. L., et al. (2015). Liposomal vaccines incorporating molecular adjuvants and intrastructural T-cell help promote the immunogenicity of HIV membrane-proximal external region peptides. Vaccine 33, 861-868. doi: 10.1016/j.vaccine.2014.12.045

Haque, S., Whittaker, M., McIntosh, M. P., Pouton, C. W., Phipps, S., and Kaminskas, L. M. (2018). A comparison of the lung clearance kinetics of solid lipid nanoparticles and liposomes by following the $3 \mathrm{H}$-labelled structural lipids after pulmonary delivery in rats. Eur. J. Pharm. Biopharm. 125, 1-12. doi: 10.1016/j.ejpb.2018.01.001

Hassan, S. A., Sheikh, F. N., Jamal, S., Ezeh, J. K., and Akhtar, A. (2020). Coronavirus (COVID-19): a review of clinical features, diagnosis, and treatment. Cureus 12:e7355. doi: 10.7759/cureus.7355

Heinimäki, S., Hankaniemi, M. M., Sioofy-Khojine, A. B., Laitinen, O. H., Hyöty, H., Hytönen, V. P., et al. (2019). Combination of three virus-derived nanoparticles as a vaccine against enteric pathogens; enterovirus, norovirus and rotavirus. Vaccine 37, 7509-7518. doi: 10.1016/j.vaccine.2019.09.072

Hennig, R., Veser, A., Kirchhof, S., and Goepferich, A. (2015). Branched polymerdrug conjugates for multivalent blockade of angiotensin II receptors. Mol. Pharm. 12, 3292-3302. doi: 10.1021/acs.molpharmaceut.5b00301

Hirano, T., and Murakami, M. (2020). COVID-19: A new virus, but a familiar receptor and cytokine release syndrome. Immunity 52, 731-733. doi: 10.1016/j.immuni.2020.04.003

Hiremath, J., Kang, K., Il, X.ia, M., Elaish, M., and Binjawadagi, B., Ouyang, K., et al. (2016). Entrapment of H1N1 influenza virus derived conserved peptides in PLGA nanoparticles enhances $\mathrm{T}$ cell response and vaccine efficacy in pigs. PLOS ONE 11, 1-15. doi: 10.1371/journal.pone.01 51922

Hoffmann, M., Kleine-Weber, H., Krüger, N., Müller, M., Drosten, C., and Pöhlmann, S. (2020a). The novel coronavirus 2019 (2019-nCoV) uses the SARS-coronavirus receptor ACE2 and the cellular protease TMPRSS2 for entry into target cells. bioRxiv [Preprint]. doi: 10.1101/2020.01.31.929042

Hoffmann, M., Kleine-Weber, H., Schroeder, S., Krüger, N., Herrler, T., Erichsen, S., et al. (2020b). SARS-CoV-2 cell entry depends on ACE2 and TMPRSS2 and is blocked by a clinically proven protease inhibitor. Cell 181, 271.e8-280.e8. doi: 10.1016/j.cell.2020.02.052

Holshue, M. L., DeBolt, C., Lindquist, S., Lofy, K. H., Wiesman, J., Bruce, H., et al. (2020). First case of 2019 novel coronavirus in the United States. N. Engl. J. Med. 382, 929-936. doi: 10.1056/NEJMoa2001191

Hu, C.-M. J., Chen, Y.-T., Fang, Z.-S., Chang, W.-S., and Chen, H.-W (2018). Antiviral efficacy of nanoparticulate vacuolar ATPase inhibitors against influenza virus infection. Int. J. Nanomedicine 14, 8579-8593. doi: $10.2147 /$ IJN.S185806

Hua, J., Wang, G., Huang, M., Hua, S., and Yang, S. (2020). A visual approach for the SARS (severe acute respiratory syndrome) outbreak data analysis. Int. J. Environ. Res. Public Heal. 17. doi: 10.3390/ijerph17113973

Huang, C., Wang, Y., Li, X., Ren, L., Zhao, J., Hu, Y., et al. (2020). Clinical features of patients infected with 2019 novel coronavirus in Wuhan, China. Lancet 395, 497-506. doi: 10.1016/S0140-6736(20)30183-5

Huang, Y., and Gui, S. (2018). Factors affecting the structure of lyotropic liquid crystals and the correlation between structure and drug diffusion. RSC Adv. 8, 6978-6987. doi: 10.1039/C7RA12008G

Huang, Y., Xu, T., Wang, W., Wen, Y., Li, K., Qian, L., et al. (2020). Lateral flow biosensors based on the use of micro- and nanomaterials: a review on recent developments. Microchim. Acta 187:70. doi: 10.1007/s00604-019-3822-x

Hussain, S., Ji, Z., Taylor, A. J., DeGraff, L. M., George, M., Tucker, C. J., et al. (2016). Multiwalled carbon nanotube functionalization with high molecular weight hyaluronan significantly reduces pulmonary injury. ACS Nano 10, 7675-7688. doi: 10.1021/acsnano.6b03013

Iannazzo, D., Pistone, A., Ferro, S., De Luca, L., Monforte, A. M., Romeo, R., et al. (2018). Graphene quantum dots based systems as HIV inhibitors. Bioconjug. Chem. 29, 3084-3093. doi: 10.1021/acs.bioconjchem.8b00448

Iannazzo, D., Pistone, A., Galvagno, S., Ferro, S., De Luca, L., Monforte, A. M., et al. (2015). Synthesis and anti-HIV activity of carboxylated and drug-conjugated multi-walled carbon nanotubes. Carbon 82, 548-561. doi: 10.1016/j.carbon.2014.11.007

Itani, R., Tobaiqy, M., and Al Faraj, A. (2020). Optimizing use of theranostic nanoparticles as a life-saving strategy for treating COVID-19 patients. Theranostics 10, 5932-5942. doi: 10.7150/thno.46691

Jain, S., Mistry, M. A., and Swarnakar, N. K. (2011). Enhanced dermal delivery of acyclovir using solid lipid nanoparticles. Drug Deliv. Transl. Res. 1, 395-406. doi: 10.1007/s13346-011-0036-0

Jesus, S., Soares, E., Costa, J., Borchard, G., and Borges, O. (2016). Immune response elicited by an intranasally delivered HBsAg low-dose adsorbed to poly- $\varepsilon$-caprolactone based nanoparticles. Int. J. Pharm. 504, 59-69. doi: 10.1016/j.ijpharm.2016.03.013

Jiang, S., Hillyer, C., and Du, L. (2020). Neutralizing antibodies against SARS-CoV-2 and other human coronaviruses. Trends Immunol.41, 355-359. doi: 10.1016/j.it.2020.03.007

Jin, Z., Liu, J.-Y., Feng, R., Ji, L., Jin, Z.-L., and Li, H.-B. (2020). Drug treatment of coronavirus disease 2019 (COVID-19) in China. Eur. J. Pharmacol. 883:173326. doi: 10.1016/j.ejphar.2020.173326 
Jorgensen, S. C. J., Kebriaei, R., and Dresser, L. D. (2020). Remdesivir: Review of pharmacology, pre-clinical data and emerging clinical experience for COVID-19. Pharmacother. J. Hum. Pharmacol. Drug Ther.40, 659-671. doi: $10.1002 /$ phar. 2429

Joshi, M. S. (2020). Researchers Come Eco-Friendly and Non-Toxic Handwash. Available online at: https://www.sakaltimes.com/pune/researchers-come-ecofriendly-and-non-toxic-handwash- 50456 (accessed June 24, 2020).

Jung, S.-Y., Kang, K. W., Lee, E.-Y., Seo, D.-W., Kim, H.-L., Kim, H., et al. (2018). Heterolous prime-boost vaccination with adenoviral vector and protein nanoparticles induces both Th1 and Th2 responses against middle east respiratory syndrome coronavirus. Vaccine 36, 3468-3476. doi: $10.1016 /$ j.vaccine.2018.04.082

Justino, C. I. L., Gomes, A. R., Freitas, A. C., Duarte, A. C., and Rocha-Santos, T. A. P. (2017). Graphene based sensors and biosensors. Trends Anal. Chem. 91, 53-66. doi: 10.1016/j.trac.2017.04.003

Kabiri, M., Sankian, M., Sadri, K., and Tafaghodi, M. (2018). Robust mucosal and systemic responses against HTLV-1 by delivery of multi-epitope vaccine in PLGA nanoparticles. Eur. J. Pharm. Biopharm. 133, 321-330. doi: 10.1016/j.ejpb.2018.11.003

Kandeel, M., and Al-Nazawi, M. (2020). Virtual screening and repurposing of FDA approved drugs against COVID-19 main protease. Life Sci. 251:117627. doi: 10.1016/j.lfs.2020.117627

Kanekiyo, M., Wei, C. J., Yassine, H. M., McTamney, P. M., Boyington, J. C., Whittle, J. R. R., et al. (2013). Self-assembling influenza nanoparticle vaccines elicit broadly neutralizing H1N1 antibodies. Nature 499, 102-106. doi: 10.1038/nature12202

Karami, Z., and Hamidi, M. (2016). Cubosomes: remarkable drug delivery potential. Drug Discov. Today 21, 789-801. doi: 10.1016/j.drudis.2016.01.004

Käsermann, F., and Kempf, C. (1998). Buckminsterfullerene and photodynamic inactivation of viruses. Rev. Med. Virol. 8, 143-151.doi: 10.1002/(SICI)10991654(199807/09)8:3<143::AID-RMV214>3.0.CO;2-B

Katz, U., Achiron, A., Sherer, Y., and Shoenfeld, Y. (2007). Safety of intravenous immunoglobulin (IVIG) therapy. Autoimmun. Rev. 6, 257-259. doi: 10.1016/j.autrev.2006.08.011

Kaur, G., Narang, R. K., Rath, G., and Goyal, A. K. (2012). Advances in pulmonary delivery of nanoparticles. Artif. Cells Blood Substitutes Biotechnol. 40, 75-96. doi: 10.3109/10731199.2011.592494

Keller, M. A., and Stiehm, E. R. (2000). Passive immunity in prevention and treatment of infectious diseases. Clin Microbiol Rev. 13, 602-614. doi: $10.1128 / \mathrm{cmr} \cdot 13.4 .602-614.2000$

Kerry, R. G., Malik, S., Redda, Y. T., Sahoo, S., Patra, J. K., and Majhi, S. (2019). Nano-based approach to combat emerging viral (NIPAH virus) infection. Nanomed. Nanotechnol. Biol. Med. 18, 196-220. doi: 10.1016/j.nano.2019.03.004

Khalili, J. S., Zhu, H., Mak, N. S. A., Yan, Y., and Zhu, Y. (2020). Novel coronavirus treatment with ribavirin: groundwork for an evaluation concerning COVID-19. J. Med. Virol. 92, 740-746. doi: 10.1002/jmv.25798

Khanna, N., Widmer, A. F., Decker, M., Steffen, I., Halter, J., Heim, D., et al. (2008). Respiratory syncytial virus infection in patients with hematological diseases: single-center study and review of the literature. Clin. Infect. Dis. 46, 402-412. doi: $10.1086 / 525263$

Khosa, A., Reddi, S., and Saha, R. N. (2018). Nanostructured lipid carriers for site-specific drug delivery. Biomed. Pharmacother. 103, 598-613. doi: 10.1016/j.biopha.2018.04.055

Kim (2020). Reusable Nano-Filtered Face Mask Could Relieve COVID-19 Supply Issues. Available online at: https://nano-magazine.com/news/2020/3/18/ reusable-nano-filtered-face-mask-could-relieve-covid-19-supply-issues (accessed July 22, 2020).

Kim, D. S., Kim, Y. T., Hong, S. B., Kim, J., Huh, N. S., Lee, M. K., et al. (2016). Development of lateral flow assay based on size-controlled gold nanoparticles for detection of hepatitis B surface antigen. Sensors 16:2154. doi: $10.3390 / \mathrm{s} 16122154$

Kim, J., Yeom, M., Lee, T., Kim, H. O., Na, W., Kang, A., et al. (2020). Porous gold nanoparticles for attenuating infectivity of influenza A virus. J. Nanobiotechnol. 18, 1-11. doi: 10.1186/s12951-020-00611-8

Kim, Y., Park, E. J., and Na, D. H. (2018). Recent progress in dendrimerbased nanomedicine development. Arch. Pharm. Res. 41, 571-582. doi: $10.1007 /$ s12272-018-1008-4
Koczula, K. M., and Gallotta, A. (2016). Lateral flow assays. Essays Biochem. 60 , 111-120. doi: 10.1042/EBC20150012

Kolyvushko, O., Latzke, J., Dahmani, I., Osterrieder, N., Chiantia, S., and Azab, W. (2020). Differentially-charged liposomes interact with alphaherpesviruses and interfere with virus entry. Pathogens 9, 1-9. doi: 10.3390/pathogens9050359

Kulkarni, C. V. (2012). Lipid crystallization: from self-assembly to hierarchical and biological ordering. Nanoscale 4, 5779-5791. doi: 10.1039/c2nr31465g

Kumar, V., O’Donnell, S. C., Sang, D. L., Maggard, P. A., and Wang, G. (2019). Harnessing plasmon-induced hot carriers at the interfaces with ferroelectrics. Front. Chem. 7:299. doi: 10.3389/fchem.2019.00299

LaBauve, A. E., Rinker, T. E., Noureddine, A., Serda, R. E., Howe, J. Y., Sherman, M. B., et al. (2018). Lipid-coated mesoporous silica nanoparticles for the delivery of the ml336 antiviral to inhibit encephalitic alphavirus infection. Sci. Rep. 8:e32033. doi: 10.1038/s41598-018-32033-w

Lai, C.-C., Shih, T.-P., Ko, W.-C., Tang, H.-J., and Hsueh, P.-R. (2020). Severe acute respiratory syndrome coronavirus 2 (SARS-CoV-2) and coronavirus disease2019 (COVID-19): the epidemic and the challenges. Int. J. Antimicrob. Agents 55:105924. doi: 10.1016/j.ijantimicag.2020.105924

Lai, Y.-L., Mehta, R. C., Thacker, A. A., Yoo, S.-D., McNamara, P. J., and DeLuca, P. P. (1993). Sustained bronchodilation with isoproterenol poly (glycolide-colactide) microspheres. Pharm. Res. 10, 119-125. doi: 10.1023/A:1018989400517

Lara, H. H., Ayala-Nuñez, N. V., Ixtepan-Turrent, L., and Rodriguez-Padilla, C. (2010). Mode of antiviral action of silver nanoparticles against HIV-1. J. Nanobiotechnol. 8:1. doi: 10.1186/1477-3155-8-1

Lau, S. K. P., and Chan, J. F. W. (2015). Coronaviruses: emerging and re-emerging pathogens in humans and animals. Virol. J. 12:209. doi: 10.1186/s12985-015-0432-z

Law, S., Leung, A. W., and Xu, C. (2020). Severe acute respiratory syndrome (SARS) and coronavirus disease-2019 (COVID-19): From causes to preventions in Hong Kong. Int. J. Infect. Dis. 94, 156-163. doi: $10.1016 /$ j.ijid.2020.03.059

Layqah, L. A., and Eissa, S. (2019). An electrochemical immunosensor for the corona virus associated with the middle east respiratory syndrome using an array of gold nanoparticle-modified carbon electrodes. Microchim. Acta 186:224. doi: 10.1007/s00604-019-3345-5

Le, R. Q., Li, L., Yuan, W., Shord, S. S., Nie, L., Habtemariam, B. A., et al. (2018). FDA approval summary: tocilizumab for treatment of chimeric antigen receptor T cell-induced severe or life-threatening cytokine release syndrome. Oncologist 23, 943-947. doi: 10.1634/theoncologist.2018-0028

Le, T. T., Andreadakis, Z., Kumar, A., Román, R. G., Tollefsen, S., Saville, M., et al. (2020). The COVID-19 vaccine development landscape. Nat. Rev. Drug Discov. 19, 305-306. doi: 10.1038/d41573-020-00073-5

Le, T. T., Chang, P., Benton, D. J., Mccauley, J. W., Iqbal, M., and Cass, A. E. G. (2017). Dual recognition element lateral flow assay toward multiplex strain specific influenza virus detection. Anal. Chem. 89, 6781-6786. doi: 10.1021 acs.analchem.7b01149

Lee, C., Jeong, J., Lee, T., Zhang, W., Xu, L., Choi, J. E., et al. (2018). Virusmimetic polymer nanoparticles displaying hemagglutinin as an adjuvant-free influenza vaccine. Biomaterials 183, 234-242. doi: 10.1016/j.biomaterials.2018. 08.036

Lee, D., Shin, Y., Chung, S., Hwang, K. S., Yoon, D. S., and Lee, J. H. (2016). Simple and highly sensitive molecular diagnosis of zika virus by lateral flow assays. Anal. Chem. 88, 12272-12278. doi: 10.1021/acs.analchem.6b03460

Lee, E. B. (2018). A review of sarilumab for the treatment of rheumatoid arthritis. Immunotherapy 10, 57-65. doi: 10.2217/imt-2017-0075

Lee, E. C., Nguyen, C. T. H., Strounina, E., Davis-Poynter, N., and Ross, B. P. (2018). Structure-activity relationships of GAG mimetic-functionalized mesoporous silica nanoparticles and evaluation of acyclovir-loaded antiviral nanoparticles with dual mechanisms of action. ACS Omega 3, 1689-1699. doi: 10.1021 /acsomega.7b01662

Lee, Y. T., Ko, E. J., Kim, K. H., Hwang, H. S., Lee, Y., Kwon, Y. M., et al. (2017) Cellular immune correlates preventing disease against respiratory syncytial virus by vaccination with virus-like nanoparticles carrying fusion proteins. $J$. Biomed. Nanotechnol. 13, 84-98. doi: 10.1166/jbn.2017.2341

Lembo, D., Donalisio, M., Civra, A., Argenziano, M., and Cavalli, R. (2018). Nanomedicine formulations for the delivery of antiviral drugs: a promising solution for the treatment of viral infections. Expert Opin. Drug Deliv. 15, 93-114. doi: 10.1080/17425247.2017.1360863 
Li, F., Li, W., Farzan, M., and Harrison, S. C. (2005). Structure of SARS coronavirus spike receptor-binding domain complexed with receptor. Science. 309, 1864-1868. doi: 10.1126/science.1116480

Li, G., and De Clercq, E. (2020). Therapeutic options for the 2019 novel coronavirus (2019-nCoV). Nat. Rev. Drug Discov. 19, 149-150. doi: 10.1038/d41573-020-00016-0

Li, H., Liu, S.-M., Yu, X.-H., Tang, S.-L., and Tang, C.-K. (2020). Coronavirus disease 2019 (COVID-19): current status and future perspectives. Int. J. Antimicrob. Agents 55:105951. doi: 10.1016/j.ijantimicag.2020.105951

Lima, A. C., Cunha, C., Carvalho, A., Ferreira, H., and Neves, N. M. (2018). Interleukin- 6 neutralization by antibodies immobilized at the surface of polymeric nanoparticles as a therapeutic strategy for arthritic diseases. ACS Appl. Mater. Interfaces 10, 13839-13850. doi: 10.1021/acsami.8b01432

Lin, L. C. W., Huang, C. Y., Yao, B. Y., Lin, J. C., Agrawal, A., Algaissi, A., et al. (2019). Viromimetic STING agonist-loaded hollow polymeric nanoparticles for safe and effective vaccination against middle east respiratory syndrome coronavirus. Adv. Funct. Mater. 29:1807616. doi: 10.1002/adfm.201807616

Lin, Y. W., Liu, C. W., and Chang, H. T. (2009). DNA functionalized gold nanoparticles for bioanalysis. Anal. Methods 1, 14-24. doi: 10.1039/b9ay00036d

Liu, C., Zhou, Q., Li, Y., Garner, L. V., Watkins, S. P., Carter, L. J., et al. (2020). Research and development on therapeutic agents and vaccines for COVID-19 and related human coronavirus diseases. ACS Cent. Sci. 6, 315-331. doi: $10.1021 /$ acscentsci.0c00272

Liu, Q., Zheng, X., Zhang, C., Shao, X., Zhang, X., Zhang, Q., et al. (2015). Conjugating influenza a (H1N1) antigen to $n$ trimethylaminoethylmethacrylate chitosan nanoparticles improves the immunogenicity of the antigen after nasal administration. J. Med. Virol. 87, 1807-1815. doi: 10.1002/jmv.24253

Liu, W., and Li, H. (2020). COVID-19: attacks the 1-beta chain of hemoglobin and captures the porphyrin to inhibit human heme metabolism. ChemRxiv. 1-29. Available online at: https://chemrxiv.org/ndownloader/files/22283226

Lohcharoenkal, W., Wang, L., Chen, Y. C., and Rojanasakul, Y. (2014). Protein nanoparticles as drug delivery carriers for cancer therapy. BioMed. Res. Int. 1-12. doi: 10.1155/2014/180549

Lotfi, M., Hamblin, M. R., and Rezaei, N. (2020). COVID-19: Transmission, prevention, and potential therapeutic opportunities. Clin. Chim. Acta 508, 254-266. doi: 10.1016/j.cca.2020.05.044

Lu, P.-H., Ma, Y.-D., Fu, C.-Y., and Lee, G.-B. (2020). A structurefree digital microfluidic platform for detection of influenza A virus by using magnetic beads and electromagnetic forces. Lab. Chip. 20, 789-797. doi: 10.1039/C9LC01126A

Luanpitpong, S., Wang, L., and Rojanasakul, Y. (2014). The effects of carbon nanotubes on lung and dermal cellular behaviors. Nanomedicine 9, 895-912. doi: $10.2217 / \mathrm{nnm} .14 .42$

Lugade, A. A., Bharali, D. J., Pradhan, V., Elkin, G., Mousa, S. A., and Thanavala, Y. (2013). Single low-dose un-adjuvanted HBsAg nanoparticle vaccine elicits robust, durable immunity. Nanomed. Nanotechnol. Biol. Med. 9, 923-934. doi: 10.1016/j.nano.2013.03.008

Luo, F., Long, C., Wu, Z., Xiong, H., Chen, M., Zhang, X., et al. (2020). Functional silica nanospheres for sensitive detection of $\mathrm{H}_{9} \mathrm{~N}_{2}$ avian influenza virus based on immunomagnetic separation. Sensors Actuators B Chem. 310:127831. doi: 10.1016/j.snb.2020.127831

Luo, P., Liu, Y., Qiu, L., Liu, X., Liu, D., and Li, J. (2020). Tocilizumab treatment in COVID-19: a single center experience. J. Med. Virol. 92, 814-818. doi: $10.1002 / j m v .25801$

Mainardes, R. M., and Diedrich, C. (2020). The potential role of nanomedicine on COVID-19 therapeutics. Ther. Deliv. 11, 411-414. doi: 10.4155/tde-2020-0069

Mair-Jenkins, J., Saavedra-Campos, M., Baillie, J. K., Cleary, P., Khaw, F.-M., Lim, W. S., et al. (2014). The effectiveness of convalescent plasma and hyperimmune immunoglobulin for the treatment of severe acute respiratory infections of viral etiology: a systematic review and exploratory meta-analysis. J. Infect. Dis. 211, 80-90. doi: 10.1093/infdis/jiu396

Mangum, J. B., Turpin, E. A., Antao-Menezes, A., Cesta, M. F., Bermudez, E., and Bonner, J. C. (2006). Single-walled carbon nanotube (SWCNT)induced interstitial fibrosis in the lungs of rats is associated with increased levels of PDGF mRNA and the formation of unique intercellular carbon structures that bridge alveolar macrophages in situ. Part. Fibre Toxicol. 3:15. doi: $10.1186 / 1743-8977-3-15$
Mantlo, E., Bukreyeva, N., Maruyama, J., Paessler, S., and Huang, C. (2020). Antiviral activities of type I interferons to SARS-CoV-2 infection. Antiviral Res. 179:104811. doi: 10.1016/j.antiviral.2020.104811

Marando, M., and Tamburello, A. (2020). Immunoglobulins or convalescent plasma to tackle COVID-19: buying time to save lives-current situation and perspectives. Swiss Med. Wkly. 150:w20264. doi: 10.4414/smw.2020.20264

Maruyama, K., Haniu, H., Saito, N., Matsuda, Y., Tsukahara, T., Kobayashi, S., et al. (2015). Endocytosis of multiwalled carbon nanotubes in bronchial epithelial and mesothelial cells. Biomed Res. Int. 2015:793186. doi: 10.1155/2015/793186

Mazurkova, N. A., Spitsyna, Y. E., Shikina, N. V., Ismagilov, Z. R., Zagrebel'nyi, S. N., and Ryabchikova, E. I. (2010). Interaction of titanium dioxide nanoparticles with influenza virus. Nanotechnol. Russ. 5, 417-420. doi: $10.1134 /$ S1995078010050174

McClements, D. J. (2012). Nanoemulsions versus microemulsions: Terminology, differences, and similarities. Soft Matter. 8, 1719-1729. doi: $10.1039 /$ C2SM06903B

Mehta, N., Mazer-Amirshahi, M., Alkindi, N., and Pourmand, A. (2020). Pharmacotherapy in COVID-19; a narrative review for emergency providers. Am. J. Emerg. Med. 38, 1488-1493. doi: 10.1016/j.ajem.2020.04.035

Mertins, O., Mathews, P. D., and Angelova, A. (2020). Advances in the design of ph-sensitive cubosome liquid crystalline nanocarriers for drug delivery applications. Nanomaterials 10:963. doi: 10.3390/nano10050963

Mhlwatika, Z., and Aderibigbe, B. A. (2018). Application of dendrimers for the treatment of infectious diseases. Molecules 23:2205. doi: 10.3390/molecules 23092205

Mohamed, M., Abu Lila, A. S., Shimizu, T., Alaaeldin, E., Hussein, A., Sarhan, H. A., et al. (2019). PEGylated Liposomes: Immunological Responses. Tokushima: Taylor \& Francis. doi: 10.1080/14686996.2019.1627174

Moitra, P., Alafeef, M., Dighe, K., Frieman, M., and Pan, D. (2020). Selective naked-eye detection of SARS-CoV-2 mediated by $\mathrm{N}$ gene targeted antisense oligonucleotide capped plasmonic nanoparticles. ACS Nano 14, 7617-7627. doi: 10.1021/acsnano.0c03822

Montazer, M., and Malekzadeh, S. B. (2012). Electrospun antibacterial nylon nanofibers through in situ synthesis of nanosilver: preparation and characteristics. J. Polym. Res. 19:9980. doi: 10.1007/s10965-012-9980-8

Mora-Huertas, C. E., Fessi, H., and Elaissari, A. (2010). Polymerbased nanocapsules for drug delivery. Int. J. Pharm. 385, 113-142. doi: 10.1016/j.ijpharm.2009.10.018

Morales-Narváez, E., and Dincer, C. (2020). The impact of biosensing in a pandemic outbreak: COVID-19. Biosens. Bioelectron. 163:112274. doi: $10.1016 /$ j.bios.2020.112274

Morcol, T., Nagappan, P., Bell, S. J. D., and Cawthon, A. G. (2019). Influenza $\mathrm{A}(\mathrm{H} 5 \mathrm{~N} 1)$ virus subunit vaccine administered with CaPNP adjuvant induce high virus neutralization antibody titers in mice. AAPS PharmSciTech 20:315. doi: 10.1208/s12249-019-1530-9

Morris, D., Ansar, M., Speshock, J., Ivanciuc, T., Qu, Y., Casola, A., et al. (2019). Antiviral and immunomodulatory activity of silver nanoparticles in experimental RSV infection. Viruses 11:732. doi: 10.3390/v11080732

Mulens-Arias, V., Rojas, J. M., and Barber, D. F. (2020). The intrinsic biological identities of iron oxide nanoparticles and their coatings: unexplored territory for combinatorial therapies. Nanomaterials. 10:837. doi: 10.3390/nano10050837

Muralidharan, P., Hayes, D. J., and Mansour, H. M. (2015). Dry powder inhalers in COPD, lung inflammation and pulmonary infections. Expert Opin. Drug Deliv. 12, 947-962. doi: 10.1517/17425247.2015.977783

Murphy, F., Tchetchik, A., and Furxhi, I. (2020). Reduction of health careassociated infections (HAIs) with antimicrobial inorganic nanoparticles incorporated in medical textiles: an economic assessment. Nanomaterials 10:999. doi: 10.3390/nano10050999

Nakano, R., Ishiguro, H., Yao, Y., Kajioka, J., Fujishima, A., Sunada, K., et al. (2012). Photocatalytic inactivation of influenza virus by titanium dioxide thin film. Photochem. Photobiol. Sci. 11, 1293-1298. doi: 10.1039/c2pp05414k

Nakashima, R., Kawamoto, M., Miyazaki, S., Onishi, R., Furusaki, K., Osaki, M., et al. (2017). Evaluation of calcium hydrogen carbonate mesoscopic crystals as a disinfectant for influenza A viruses. J. Vet. Med. Sci. 79, 939-942. doi: $10.1292 / \mathrm{jvms} .16-0603$

Naqvi, A. A. T., Fatima, K., Mohammad, T., Fatima, U., Singh, I. K., Singh, A., et al. (2020). Insights into SARS-CoV-2 genome, structure, evolution, pathogenesis 
and therapies: Structural genomics approach. Biochim. Biophys. Acta Mol. Basis Dis. 1866:165878. doi: 10.1016/j.bbadis.2020.165878

Nasibulin, A. G., Kaskela, A., Mustonen, K., Anisimov, A. S., Ruiz, V., Kivisto, S., et al. (2011). Multifunctional free-standing single-walled carbon nanotube films. ACS Nano 5, 3214-3221. doi: 10.1021/nn200338r

Nasrollahzadeh, M., Sajjadi, M., Soufi, G. J., Iravani, S., and Varma, R. S. (2020). Nanomaterials and nanotechnology-associated innovations against viral infections with a focus on coronaviruses. Nanomaterials 10:1072. doi: 10.3390/nano10061072

Nassimi, M., Schleh, C., Lauenstein, H. D., Hussein, R., Hoymann, H. G., Koch, W., et al. (2010). A toxicological evaluation of inhaled solid lipid nanoparticles used as a potential drug delivery system for the lung. Eur. J. Pharm. Biopharm. 75, 107-116. doi: 10.1016/j.ejpb.2010.02.014

Nikaeen, G., Abbaszadeh, S., and Yousefinejad, S. (2020). Application of nanomaterials in treatment, anti-infection and detection of coronaviruses. Nanomedicine. 15, 1501-1512. doi: 10.2217/nnm-2020-0117

Nitulescu, G. M., Paunescu, H., Moschos, S. A., Petrakis, D., Nitulescu, G., Ion, G. N. D., et al. (2020). Comprehensive analysis of drugs to treat SARS-CoV-2 infection: Mechanistic insights into current COVID-19 therapies. Int. J. Mol. Med. 46, 467-488. doi: 10.3892/ijmm.2020.4608

Noor, N., Mutalik, S., Younas, M. W., Chan, C. Y., Thakur, S., Wang, F., et al. (2019). Durable antimicrobial behaviour from silver-graphene coated medical textile composites. Polymers 11:2000. doi: 10.3390/polym11122000

Ortiz-Prado, E., Simbaña-Rivera, K., Gómez-Barreno, L., Rubio-Neira, M., Guaman, L. P., Kyriakidis, N. C., et al. (2020). Clinical, molecular and epidemiological characterization of the SARS-CoV2 virus and the Coronavirus disease 2019 (COVID-19), a comprehensive literature review. Diagn. Microbiol. Infect. Dis. 98:115094. doi: 10.20944/preprints202004.0283.v1

Palmieri, V., and Papi, M. (2020). Can graphene take part in the fight against COVID-19? Nano Today 33:100883. doi: 10.1016/j.nantod.2020.100883

Park, K.-T., and Hwang, J. (2014). Filtration and inactivation of aerosolized bacteriophage MS2 by a CNT air filter fabricated using electro-aerodynamic deposition. Carbon 75, 401-410. doi: 10.1016/j.carbon.2014.04.019

Pfaff, F., Glück, B., Hoyer, T., Rohländer, D., Sauerbrei, A., and Zell, R. (2019). Tungsten carbide nanoparticles show a broad spectrum virucidal activity against enveloped and nonenveloped model viruses using a guideline-standardized in vitro test. Lett. Appl. Microbiol. 69, 302-309. doi: 10.1111/lam.13208

Pollock, S., Branza Nichita, N., Böhmer, A., Radulescu, C., Dwek, R. A., and Zitzmann, N. (2010). Polyunsaturated liposomes are antiviral against hepatitis $\mathrm{B}$ and $\mathrm{C}$ viruses and HIV by decreasing cholesterol levels in infected cells. Proc. Natl. Acad. Sci. U.S.A. 107, 17176-17181. doi: 10.1073/pnas.1009445107

Poon, C., and Patel, A. A. (2020). Organic and inorganic nanoparticle vaccines for prevention of infectious diseases. Nano Express. 1, 1-11. doi: 10.1088/2632-959X/ab8075

Prego, C., Paolicelli, P., Díaz, B., Vicente, S., Sánchez, A., GonzálezFernández, Á., et al. (2010). Chitosan-based nanoparticles for improving immunization against hepatitis B infection. Vaccine 28, 2607-2614. doi: $10.1016 /$ j.vaccine.2010.01.011

Price, C. F., Tyssen, D., Sonza, S., Davie, A., Evans, S., Lewis, G. R., et al. (2011). SPL7013 Gel (VivaGel ${ }^{\circledR}$ ) retains potent HIV-1 and HSV-2 inhibitory activity following vaginal administration in humans. PLoS ONE 6:e24095. doi: 10.1371/journal.pone.0024095

Puri, A., Loomis, K., Smith, B., Lee, J. H., Yavlovich, A., Heldman, E., et al. (2009). Lipid-based nanoparticles as pharmaceutical drug carriers: from concepts to clinic. Crit. Rev. Ther. Drug Carrier Syst. 26, 523-580. doi: 10.1615/CritRevTherDrugCarrierSyst.v26.i6.10

Quach, Q. H., Ang, S. K., Chu, J. H. J., and Kah, J. C. Y. (2018). Sizedependent neutralizing activity of gold nanoparticle-based subunit vaccine against dengue virus. Acta Biomater. 78, 224-235. doi: 10.1016/j.actbio.2018. 08.011

Quesada-González, D., Stefani, C., González, I., de la Escosura-Muñiz, A., Domingo, N., Mutj,é, P., et al. (2019). Signal enhancement on gold nanoparticle-based lateral flow tests using cellulose nanofibers. Biosens. Bioelectron. 141:111407. doi: 10.1016/j.bios.2019.111407

Raghuwanshi, D., Mishra, V., Das, D., Kaur, K., and Suresh, M. R. (2012). Dendritic cell targeted chitosan nanoparticles for nasal DNA immunization against SARS CoV nucleocapsid protein. Mol. Pharm. 9, 946-956. doi: 10.1021/mp200553x
Rai, M., Deshmukh, S. D., Ingle, A. P., Gupta, I. R., Galdiero, M., and Galdiero, S. (2016). Metal nanoparticles: the protective nanoshield against virus infection. Crit. Rev. Microbiol. 42, 46-56. doi: 10.3109/1040841X.2013.879849

Ramakrishna, S., Fujihara, K., Teo, W. E., Yong, T., Ma, Z., and Ramaseshan, R. (2006). Electrospun nanofibers: solving global issues. Mater. Today 9, 40-50. doi: 10.1016/S1369-7021(06)71389-X

Rao, L., Tian, R., and Chen, X. (2020). Cell-membrane-mimicking nanodecoys against infectious diseases. ACS Nano 14, 2569-2574. doi: 10.1021/acsnano.0c01665

Rashid, M., and Ralph, S. F. (2017). Carbon nanotube membranes: synthesis, properties, and future filtration applications. Nanomaterials 7:99. doi: 10.3390/nano7050099

Renu, S., Dhakal, S., Kim, E., Goodman, J., Lakshmanappa, Y. S., Wannemuehler, M. J., et al. (2018). Intranasal delivery of influenza antigen by nanoparticles, but not NKT-cell adjuvant differentially induces the expression of Bcell activation factors in mice and swine. Cell. Immunol. 329, 27-30. doi: 10.1016/j.cellimm.2018.04.005

Rezaei, M., Hosseini, S. N., Khavari-Nejad, R. A., Najafi, F., and Mahdavi, M. (2019). HBs antigen and mannose loading on the surface of iron oxide nanoparticles in order to immuno-targeting: fabrication, characterization, cellular and humoral immunoassay. Artif. Cells Nanomed. Biotechnol. 47, 1543-1558. doi: 10.1080/21691401.2019.1577888

Rodrigues, L., Kyriakos, K., Schneider, F., Dietz, H., Winter, G., Papadakis, C. M., et al. (2016). Characterization of lipid-based hexosomes as versatile vaccine carriers. Mol. Pharm. 13, 3945-3954. doi: 10.1021/acs.molpharmaceut.6b00716

Rodrigues, L., Schneider, F., Zhang, X., Larsson, E., Moodie, L. W. K., Dietz, H., et al. (2019). Cellular uptake of self-assembled phytantriol-based hexosomes is independent of major endocytic machineries. J. Colloid Interface Sci. 553, 820-833. doi: 10.1016/j.jcis.2019.06.045

Rodríguez, M. O., Covián, L. B., García, A. C., and Blanco-López, M. C. (2016). Silver and gold enhancement methods for lateral flow immunoassays. Talanta 148, 272-278. doi: 10.1016/j.talanta.2015.10.068

Rogers, J. V., Parkinson, C. V., Choi, Y. W., Speshock, J. L., and Hussain, S. M. (2008). A preliminary assessment of silver nanoparticle inhibition of monkeypox virus plaque formation. Nanoscale Res. Lett. 3, 129-133. doi: $10.1007 /$ s1 1671-008-9128-2

Rojas, M., Rodríguez, Y., Monsalve, D. M., Acosta-Ampudia, Y., Camacho, B., Gallo, J. E., et al. (2020). Convalescent plasma in Covid19: possible mechanisms of action. Autoimmun. Rev. 19:102554. doi: 10.1016/j.autrev.2020.102554

Rojas-Sánchez, L., Zhang, E., Sokolova, V., Zhong, M., Yan, H., Lu, M., et al. (2020). Genetic immunization against hepatitis B virus with calcium phosphate nanoparticles in vitro and in vivo. Acta Biomater. 110, 254-265. doi: 10.1016/j.actbio.2020.04.021

Ross, K., Senapati, S., Alley, J., Darling, R., Goodman, J., Jefferson, M., et al. (2019). Single dose combination nanovaccine provides protection against influenza A virus in young and aged mice. Biomater. Sci. 7, 809-821. doi: 10.1039/C8BM01443D

Rothan, H. A., and Byrareddy, S. N. (2020). The epidemiology and pathogenesis of coronavirus disease (COVID-19) outbreak. J. Autoimmun. 109:102433. doi: 10.1016/j.jaut.2020.102433

Russell, B., Moss, C., Rigg, A., and Van Hemelrijck, M. (2020). COVID-19 and treatment with NSAIDs and corticosteroids: should we be limiting their use in the clinical setting? Ecancer Med. Sci. 14:1023. doi: 10.3332/ecancer.202 0.1023

Sakudo, A., Yamashiro, R., Haritani, M., Furusaki, K., Onishi, R., and Onodera, T. (2020). Inactivation of non-enveloped viruses and bacteria by an electrically charged disinfectant containing meso-structure nanoparticles via modification of the genome. Int. J. Nanomed. 15, 1387-1395. doi: 10.2147/IJN.S229880

Sallard, E., Lescure, F.-X., Yazdanpanah, Y., Mentre, F., and Peiffer-Smadja, N. (2020). Type 1 interferons as a potential treatment against COVID-19. Antiviral Res. 178:104791. doi: 10.1016/j.antiviral.2020.104791

Sanchez-Guzman, D., Le Guen, P., Villeret, B., Sola, N., Le Borgne, R., Guyard, A., et al. (2019). Silver nanoparticle-adjuvanted vaccine protects against lethal influenza infection through inducing BALT and IgA-mediated mucosal immunity. Biomaterials 217:119308. doi: 10.1016/j.biomaterials.2019.119308

Sanpui, P., Zheng, X., Loeb, J. C., Bisesi Jr, J. H., Khan, I. A., Afrooz, A. R. M. N., et al. (2014). Single-walled carbon nanotubes increase pandemic influenza 
A H1N1 virus infectivity of lung epithelial cells. Part. Fibre Toxicol. 11:66. doi: 10.1186/s12989-014-0066-0

Schulze, K., Ebensen, T., Babiuk, L. A., Gerdts, V., and Guzman, C. A. (2017). Intranasal vaccination with an adjuvanted polyphosphazenes nanoparticle-based vaccine formulation stimulates protective immune responses in mice. Nanomed. Nanotechnol. Biol. Med. 13, 2169-2178. doi: 10.1016/. .nano.2017.05.012

Sekimukai, H., Iwata-Yoshikawa, N., Fukushi, S., Tani, H., Kataoka, M., Suzuki, T., et al. (2020). Gold nanoparticle-adjuvanted S protein induces a strong antigen-specific IgG response against severe acute respiratory syndromerelated coronavirus infection, but fails to induce protective antibodies and limit eosinophilic infiltration in lungs. Microbiol. Immunol. 64, 33-51. doi: 10.1111/1348-0421.12754

Senanayake, S. L. (2020). Drug repurposing strategies for COVID-19. Futur. Drug Discov. 2:10. doi: 10.4155/fdd-2020-0010

Seo, G., Lee, G., Kim, M. J., Baek, S. H., Choi, M., Ku, K. B., et al. (2020). Rapid detection of COVID-19 causative virus (SARS-CoV-2) in human nasopharyngeal swab specimens using field-effect transistor-based biosensor. ACS Nano 14, 5135-5142. doi: 10.1021/acsnano.0c02823

Shah, M. R., Imran, M., and Ullah, S. (2017). Lipid-Based Nanocarriers for Drug Delivery and Diagnosis. doi: 10.1016/B978-0-323-52729-3.00009-3

Sharma, R., Agarwal, M., Gupta, M., Somendra, S., and Saxena, S. K. (2020). "Clinical characteristics and differential clinical diagnosis of novel coronavirus disease 2019 (COVID-19)," in Coronavirus Disease 2019 (COVID19): Epidemiology, Pathogenesis, Diagnosis, and Therapeutics, ed. S. K. Saxena (Singapure: Springer), 55-70. doi: 10.1007/978-981-15-4814-7_6

Shehata, M. M., Mostafa, A., Teubner, L., Mahmoud, S. H., Kandeil, A., Elshesheny, R., et al. (2019). Bacterial outer membrane vesicles (OMVs)based dual vaccine for influenza a H1N1 virus and MERS-CoV. Vaccines 7:46. doi: $10.3390 /$ vaccines 7020046

Shen, T. W., Fromen, C. A., Kai, M. P., Luft, J. C., Rahhal, T. B., Robbins, G. R., et al. (2015). Distribution and cellular uptake of PEGylated polymeric particles in the lung towards cell-specific targeted delivery. Pharm. Res. 32, 3248-3260. doi: 10.1007/s11095-015-1701-7

Shereen, M. A., Khan, S., Kazmi, A., Bashir, N., and Siddique, R. (2020). COVID19 infection: origin, transmission, and characteristics of human coronaviruses. J. Adv. Res. 24, 91-98. doi: 10.1016/j.jare.2020.03.005

Sheridan, C. (2020). Fast, portable tests come online to curb coronavirus pandemic. Nat. Biotechnol. 38, 515-518. doi: 10.1038/d41587-020-00010-2

Shim, B. S., Park, S. M., Quan, J. S., Jere, D., Chu, H., Song, M. K., et al. (2010). Intranasal immunization with plasmid DNA encoding spike protein of SARS-coronavirus/polyethylenimine nanoparticles elicits antigenspecific humoral and cellular immune responses. BMC Immunol. 11:65. doi: 10.1186/1471-2172-11-65

Si, Y., Zhang, Z., Wu, W., Fu, Q., Huang, K., Nitin, N., et al. (2018). Daylightdriven rechargeable antibacterial and antiviral nanofibrous membranes for bioprotective applications. Sci. Adv. 4:eaar5931. doi: 10.1126/sciadv.aar5931

Simon, H. U., and Späth, P. J. (2003). IVIG mechanisms of action. Allergy 58, 543-552. doi: 10.1034/j.1398-9995.2003.00239.x

Singh, A. P., Biswas, A., Shukla, A., and Maiti, P. (2019). Targeted therapy in chronic diseases using nanomaterial-based drug delivery vehicles. Signal Transduct. Target. Ther. 4, 1-21. doi: 10.1038/s41392-019-0068-3

Singh, L., Kruger, H. G., Maguire, G. E. M., Govender, T., and Parboosing, R. (2017). The role of nanotechnology in the treatment of viral infections. Ther. Adv. Infect. Dis. 4, 105-131. doi: 10.1177/2049936117713593

Singh, R., Hong, S., and Jang, J. (2017). Label-free detection of influenza viruses using a reduced graphene oxide-based electrochemical immunosensor integrated with a microfluidic platform. Sci. Rep. 2017:42771. doi: $10.1038 /$ srep 42771

Singh, R., and Lillard, J. W. (2009). Nanoparticle-based targeted drug delivery. Exp. Mol. Pathol. 86, 215-223. doi: 10.1016/j.yexmp.2008.12.004

Skrastina, D., Petrovskis, I., Lieknina, I., Bogans, J., Renhofa, R., Ose, V., et al. (2014). Silica nanoparticles as the adjuvant for the immunisation of mice using hepatitis B core virus-like particles. PLoS ONE 9:e114006. doi: 10.1371/journal.pone.0114006

Soenen, S. J., Rivera-Gil, P., Montenegro, J.-M., Parak, W. J., De Smedt, S. C., and Braeckmans, K. (2011). Cellular toxicity of inorganic nanoparticles: Common aspects and guidelines for improved nanotoxicity evaluation. Nano Today 6 , 446-465. doi: 10.1016/j.nantod.2011.08.001

Song, Z., Wang, X., Zhu, G., Nian, Q., Zhou, H., Yang, D., et al. (2015). Virus capture and destruction by label-free graphene oxide for detection and disinfection applications. Small 11, 1171-1176. doi: 10.1002/smll.201401706

Srivastava, N., and Saxena, S. K. (2020). Prevention and control strategies for SARS-CoV-2 Infection. Coronavirus Disease 2019 2019, 127-140. doi: 10.1007/978-981-15-4814-7_11

Stanford, M. G., Li, J. T., Chen, Y., McHugh, E. A., Liopo, A., Xiao, H., et al. (2019). Self-sterilizing laser-induced graphene bacterial air filter. ACS Nano 13, 11912-11920. doi: 10.1021/acsnano.9b05983

Staroverov, S. A., Volkov, A. A., Mezhenny, P. V., Domnitsky, I. Y., Fomin, A. S., Kozlov, S. V., et al. (2019). Prospects for the use of spherical gold nanoparticles in immunization. Appl. Microbiol. Biotechnol. 103, 437-447. doi: 10.1007/s00253-018-9476-5

Syedmoradi, L., Daneshpour, M., Alvandipour, M., Gomez, F. A., Hajghassem, H., and Omidfar, K. (2017). Point of care testing: The impact of nanotechnology. Biosens. Bioelectron. 87, 373-387. doi: 10.1016/j.bios.2016.08.084

Tao, W., Hurst, B. L., Shakya, A. K., Uddin, M. J., Ingrole, R. S. J., HernandezSanabria, M., et al. (2017). Consensus M2e peptide conjugated to gold nanoparticles confers protection against $\mathrm{H}_{1} \mathrm{~N}_{1}, \mathrm{H}_{3} \mathrm{~N}_{2}$ and $\mathrm{H}_{5} \mathrm{~N}_{1}$ influenza $A$ viruses. Antiviral Res. 141, 62-72. doi: 10.1016/j.antiviral.2017.01.021

Tao, W., Ziemer, K. S., and Gill, H. S. (2014). Gold nanoparticle-M2e conjugate coformulated with $\mathrm{CpG}$ induces protective immunity against influenza $\mathrm{A}$ virus. Nanomedicine 9, 237-251. doi: 10.2217/nnm.13.58

Tariq, A., Mateen, R., Sohail Afzal, S., and Saleem, M. (2020). Paromomycin: a potential dual targeted drug effectively inhibits both spike (S1) and main protease of COVID-19. Int. J. Infect. Dis. 98, 166-175. doi: 10.2139/ssrn.3575839

Teng, Z., Sun, S., Chen, H., Huang, J., Du, P., Dong, H., et al. (2018). Goldenstar nanoparticles as adjuvant effectively promotes immune response to foot-and-mouth disease virus-like particles vaccine. Vaccine 36, 6752-6760. doi: 10.1016/j.vaccine.2018.09.030

Thapa, R. K., Baskaran, R., Madheswaran, T., Rhyu, J. Y., Kim, J. O., Yong, C. S., et al. (2013). Effect of saturated fatty acids on tacrolimus-loaded liquid crystalline nanoparticles. J. Drug Deliv. Sci. Technol. 23, 137-141. doi: 10.1016/S1773-2247(13)50021-9

Thomas, C., Rawat, A., Hope-Weeks, L., and Ahsan, F. (2011). Aerosolized PLA and PLGA nanoparticles enhance humoral, mucosal and cytokine responses to hepatitis B vaccine. Mol. Pharm. 8, 405-415. doi: 10.1021/mp100255c

Tran, N., Mulet, X., Hawley, A. M., Hinton, T. M., Mudie, S. T., Muir, B. W., et al. (2015). Nanostructure and cytotoxicity of self-assembled monooleincapric acid lyotropic liquid crystalline nanoparticles. RSC Adv. 5, 26785-26795. doi: 10.1039/C5RA02604K

Tran, V. T., Kim, J., Tufa, L. T., Oh, S., Kwon, J., and Lee, J. (2018). Magnetoplasmonic nanomaterials for biosensing/imaging and in vitro/in vivo biousability. Anal. Chem. 90, 225-239. doi: 10.1021/acs.analchem.7b04255

Turmagambetova, A. S., Alexyuk, M. S., Bogoyavlenskiy, A. P., Alexyuk, P. G., Zaitseva, I. A., Omirtaeva, E. S., et al. (2020). Effect of the nanocapsulated adjuvant Sapomax on the expression of some immune response genes. Arch. Virol. 165, 1445-1451. doi: 10.1007/s00705-020-04619-1

U.S. National Library of Medicine (2020). ClinicalTrials.gov. Available online at: https://clinicaltrials.gov/ (accessed July 22, 2020).

Udugama, B., Kadhiresan, P., Kozlowski, H. N., Malekjahani, A., Osborne, M., Li, V. Y. C., et al. (2020). Diagnosing COVID-19: the disease and tools for detection. ACS Nano 14, 3822-3835. doi: 10.1021/acsnano. $0 \mathrm{c} 02624$

Viswanathan, G., Kane, D. B., and Lipowicz, P. J. (2004). High efficiency fine particulate filtration using carbon nanotube coatings. Adv. Mater. 16, 2045-2049. doi: 10.1002/adma.200400463

Walls, A. C., Park, Y.-J., Tortorici, M. A., Wall, A., McGuire, A. T., and Veesler, D. (2020). Structure, function, and antigenicity of the SARSCoV-2 spike glycoprotein. Cell 181, 281.e6-292.e6. doi: 10.1016/j.cell.2020. 02.058

Wang, C., Horby, P. W., Hayden, F. G., and Gao, G. F. (2020a). A novel coronavirus outbreak of global health concern. Lancet 395, 470-473. doi: 10.1016/S0140-6736(20)30185-9 
Wang, C., Li, W., Drabek, D., Okba, N. M. A., van Haperen, R., Osterhaus, A. D. M. E., et al. (2020b). A human monoclonal antibody blocking SARS-CoV-2 infection. Nat. Commun. 11, 1-6. doi: 10.1038/s41467-020-16452-w

Wang, C., Zhu, W., and Wang, B. Z. (2017). Dual-linker gold nanoparticles as adjuvanting carriers for multivalent display of recombinant influenza hemagglutinin trimers and flagellin improve the immunological responses in vivo and in vitro. Int. J. Nanomed. 12, 4747-4762. doi: 10.2147/IJN.S137222

Wang, L., Wang, Y., Ye, D., and Liu, Q. (2020). Review of the 2019 novel coronavirus (SARS-CoV-2) based on current evidence. Int. J. Antimicrob. Agents 55:105948. doi: 10.1016/j.ijantimicag.2020.105948

Wang, M., Cao, R., Zhang, L., Yang, X., Liu, J., Xu, M., et al. (2020). Remdesivir and chloroquine effectively inhibit the recently emerged novel coronavirus (2019-nCoV) in vitro. Cell Res. 30, 269-271. doi: 10.1038/s41422-020-0282-0

Wang, N., Wei, C., Zhang, Z., Liu, T., and Wang, T. (2020). Aluminum nanoparticles acting as a pulmonary vaccine adjuvant-delivery system (VADS) able to safely elicit robust systemic and mucosal immunity. J. Inorg. Organomet. Polym. Mater. 9, 1-15. doi: 10.1007/s10904-020-01572-z

Weber, C., Voigt, M., Simon, J., Danner, A. K., Frey, H., Mailänder, V., et al. (2019). Functionalization of liposomes with hydrophilic polymers results in macrophage uptake independent of the protein corona. Biomacromolecules 20, 2989-2999. doi: 10.1021/acs.biomac.9b00539

Weiss, C., Carriere, M., Fusco, L., Capua, I., Regla-Nava, J. A., Pasquali, M., et al. (2020). Toward nanotechnology-enabled approaches against the COVID-19 pandemic. ACS Nano 14, 6383-6406. doi: 10.1021/acsnano.0c 03697

Williams, M. J., and Corr, S. A. (2013). Magnetic nanoparticles for targeted cancer diagnosis and therapy. Front. Nanosci. 5, 29-63. doi: 10.1016/B978-0-08-098338-7.00002-9

World Health Organization (2020a). Draft Landscape of COVID-19 Candidate Vaccines. Available online at: https://www.who.int/publications/m/item/draftlandscape- of-covid-19-candidate-vaccines (accessed July 22, 2020).

World Health Organization (2020b). Immunization. Available online at: https:// www.who.int/news-room/facts-in-pictures/detail/immunization (accessed July 22, 2020).

World Health Organization (2020c). Transmission of SARS-CoV-2: Implications for Infection Prevention Precautions: Scientific Brief. World Health Organization. Available online at: https://www.who.i nt/emergencies/diseases/novel-coronavirus-2019?gclid=EAIaIQobChMIz4S8h Iqr6wIVxoGRCh1pNQndEAAYASAAEgLpmPD_BwE (accessed July 22, 2020).

World Health Organization (2020d). WHO Coronavirus Disease (COVID19) Dashboard. Available online at: https://covid19.who.int/?gclid= EAIaIQobChMIgsDG0Ljh6gIVh4iRCh3-1QnoEAAYASABEgIqU_D_BwE (accessed July 22, 2020).

Wrapp, D., Wang, N., Corbett, K. S., Goldsmith, J. A., Hsieh, C.-L., Abiona, O., et al. (2020). Cryo-EM structure of the 2019-nCoV spike in the prefusion conformation. Science 367, 1260-1263. doi: 10.1126/science.abb2507

Wu, C., Liu, Y., Yang, Y., Zhang, P., Zhong, W., Wang, Y., et al. (2020). Analysis of therapeutic targets for SARS-CoV-2 and discovery of potential drugs by computational methods. Acta Pharm. Sin. B. 10, 766-788. doi: 10.1016/j.apsb.2020.02.008

Xu, L., Liu, Y., Chen, Z., Li, W., Liu, Y., Wang, L., et al. (2012). Surface-engineered gold nanorods: promising DNA vaccine adjuvant for HIV-1 treatment. Nano Lett. 12, 2003-2012. doi: 10.1021/nl300027p

Xu, X., Han, M., Li, T., Sun, W., Wang, D., Fu, B., et al. (2020). Effective treatment of severe COVID-19 patients with tocilizumab. Proc. Natl. Acad. Sci. U.S.A. 117, 10970-10975. doi: 10.1073/pnas.2005615117

Yan, R., Zhang, Y., Li, Y., Xia, L., Guo, Y., and Zhou, Q. (2020). Structural basis for the recognition of SARS-CoV-2 by full-length human ACE2. Science 367, 1444-1448. doi: 10.1126/science.abb2762

Yang, X., Yang, M., Pang, B., Vara, M., and Xia, Y. (2015). Gold nanomaterials at work in biomedicine. Chem. Rev. 115, 10410-10488. doi: 10.1021/acs.chemrev.5b00193

Yang, X. X., Li, C. M., and Huang, C. Z. (2016). Curcumin modified silver nanoparticles for highly efficient inhibition of respiratory syncytial virus infection. Nanoscale 8, 3040-3048. doi: 10.1039/C5NR07 $918 \mathrm{G}$
Yang, Y., Xing, R., Liu, S., Qin, Y., Li, K., Yu, H., et al. (2020). Chitosan, hydroxypropyltrimethyl ammonium chloride chitosan and sulfated chitosan nanoparticles as adjuvants for inactivated Newcastle disease vaccine. Carbohydr. Polym. 229:115423. doi: 10.1016/j.carbpol.2019.115423

Ye, Y., Ji, J., Pi, F., Yang, H., Liu, J., Zhang, Y., et al. (2018). A novel electrochemical biosensor for antioxidant evaluation of phloretin based on cell-alginate/?-cysteine/gold nanoparticle-modified glassy carbon electrode. Biosens. Bioelectron. 119, 119-125. doi: 10.1016/j.bios.2018.07.051

Yee, J., Unger, L., Zadravecz, F., Cariello, P., Seibert, A., Johnson, M. A., et al. (2020). Novel coronavirus 2019 (COVID-19): Emergence and implications for emergency care. J. Am. Coll. Emerg. Physicians Open 1, 63-69. doi: 10.1002/emp2.12034

Yeh, Y.-T., Gulino, K., Zhang, Y., Sabestien, A., Chou, T.-W., Zhou, B., et al. (2020). A rapid and label-free platform for virus capture and identification from clinical samples. Proc. Natl. Acad. Sci. U.S.A. 117, 895LP - 901. doi: $10.1073 /$ pnas.1910113117

Yeh, Y.-T., Tang, Y., Sebastian, A., Dasgupta, A., Perea-Lopez, N., Albert, I., et al. (2016). Tunable and label-free virus enrichment for ultrasensitive virus detection using carbon nanotube arrays. Sci. Adv. 2:e1601026. doi: 10.1126/sciadv.1601026

Yoo, D., Guk, K., Kim, H., Khang, G., Wu, D., and Lee, D. (2013). Antioxidant polymeric nanoparticles as novel therapeutics for airway inflammatory diseases. Int. J. Pharm. 450, 87-94. doi: 10.1016/j.ijpharm.2013. 04.028

Zacheo, A., Hodek, J., Witt, D., Mangiatordi, G. F., Ong, Q. K., Kocabiyik, O., et al. (2020). Multi-sulfonated ligands on gold nanoparticles as virucidal antiviral for Dengue virus. Sci. Rep. 10, 1-9. doi: 10.1038/s41598-020-65892-3

Zaman, M., Good, M. F., and Toth, I. (2013). Nanovaccines and their mode of action. Methods 60, 226-231. doi: 10.1016/j.ymeth.2013.04.014

Zarei, S. S., Soleimanian-Zad, S., and Ensafi, A. A. (2018). An impedimetric aptasensor for Shigella dysenteriae using a gold nanoparticle-modified glassy carbon electrode. Microchim. Acta 185:538. doi: 10.1007/s00604-0183075-0

Zha, L., Li, S., Pan, L., Tefsen, B., Li, Y., French, N., et al. (2020). Corticosteroid treatment of patients with coronavirus disease 2019 (COVID-19). Med. J. Aust. 212, 416-420. doi: 10.5694/mja2.50577

Zhai, J., Fong, C., Tran, N., and Drummond, C. J. (2019). Non-lamellar lyotropic liquid crystalline lipid nanoparticles for the next generation of nanomedicine. ACS Nano 13, 6178-6206. doi: 10.1021/acsnano.8b07961

Zhang, N., Li, C., Hu, Y., Li, K., Liang, J., Wang, L., et al. (2020). Current development of COVID-19 diagnostics, vaccines and therapeutics. Microbes Infect. 22, 231-235. doi: 10.1016/j.micinf.2020.05.001

Zhao, K., Chen, G., Shi, X. ming, Gao, T. ting, Li, W., Zhao, Y., et al. (2012). Preparation and efficacy of a live Newcastle disease virus vaccine encapsulated in chitosan nanoparticles. PLoS ONE 7, e53314. doi: 10.1371/journal.pone.0053314

Zhao, P., Cao, J., Zhao, L. J., Qin, Z. L., Ke, J. S., Pan, W., et al. (2005). Immune responses against SARS-coronavirus nucleocapsid protein induced by DNA vaccine. Virology 331, 128-135. doi: 10.1016/j.virol.2004.10.016

Zhao, Q., and He, Y. (2020). Challenges of convalescent plasma therapy on COVID-19. J. Clin. Virol. 127:104358. doi: 10.1016/j.jcv.2020. 104358

Zhao, Y., Zhong, Z., Low, Z.-X., and Yao, Z. (2015). A multifunctional multi-walled carbon nanotubes/ceramic membrane composite filter for air purification. RSC Adv. 5, 91951-91959. doi: 10.1039/C5RA18200J

Zheng, J., Hassan, S., Alagaili, A. N., Alshukairi, A. N., Amor, N. M. S., Mukhtar, N., et al. (2019). Middle east respiratory syndrome coronavirus seropositivity in camel handlers and their families, Pakistan. Emerg. Infect. Dis. 25, 2307-2309. doi: 10.3201/eid2512.191169

Zhong, H., Zhu, Z., Lin, J., Cheung, C. F., Lu, V. L., Yan, F., et al. (2020). Reusable and recyclable graphene masks with outstanding superhydrophobic and photothermal performances. ACS Nano 14, 6213-6221. doi: 10.1021/acsnano.0c02250

Zhou, F., Yu, T., Du, R., Fan, G., Liu, Y., Liu, Z., et al. (2020). Clinical course and risk factors for mortality of adult inpatients with COVID-19 in Wuhan, China: a retrospective cohort study. Lancet 395, 1054-1062. doi: 10.1016/S0140-6736(20)30566-3 
Zhou, Y., Vedantham, P., Lu, K., Agudelo, J., Carrion Jr, R., Nunneley, J. W., et al. (2015). Protease inhibitors targeting coronavirus and filovirus entry. Antiviral Res. 116, 76-84. doi: 10.1016/j.antiviral.2015.01.011

Zhu, H., Fohlerová, Z., Pekárek, J., Basova, E., and NeuŽil, P. (2020). Recent advances in lab-on-a-chip technologies for viral diagnosis. Biosens. Bioelectron. 153:112041. doi: 10.1016/j.bios.2020.112041

Zhu, J., Qin, F., Ji, Z., Fei, W., Tan, Z., Hu, Y., et al. (2020). Mannosemodified PLGA nanoparticles for sustained and targeted delivery in hepatitis B virus immunoprophylaxis. AAPS PharmSciTech 21:13. doi: 10.1208/s12249-019-1526-5

Zhu, N., Zhang, D., Wang, W., Li, X., Yang, B., Song, J., et al. (2020). A novel coronavirus from patients with pneumonia in China, 2019. N. Engl. J. Med. 382, 727-733. doi: 10.1056/NEJMoa2001017
Conflict of Interest: The authors declare that the research was conducted in the absence of any commercial or financial relationships that could be construed as a potential conflict of interest.

Copyright (c) 2020 Cardoso, Moreira, Comparetti, Sampaio, Ferreira, Lins and Zucolotto. This is an open-access article distributed under the terms of the Creative Commons Attribution License (CC BY). The use, distribution or reproduction in other forums is permitted, provided the original author(s) and the copyright owner(s) are credited and that the original publication in this journal is cited, in accordance with accepted academic practice. No use, distribution or reproduction is permitted which does not comply with these terms. 